\title{
Irish Maritime Trade in the Eighteenth Century: \\ A Study in Patterns of Trade, Market Structures, and Merchant Communities
}

\author{
Karen A. Cheer
}

A thesis submitted in fulfilment of the requirements for the degree of Master of Arts in History at

Victoria University of Wellington, New Zealand 


\begin{abstract}
Ireland has a centuries-long history of maritime and economic interaction with Great Britain and other more distant communities on the Atlantic rim. In the last forty years of academic writing on the main themes of Ireland's economic history, very few historians have examined the late-eighteenth century maritime trade data. The original Customs logs or port books are lost but other sources of information remain.

This thesis uses a new source of information, Richard Eaton's A Daily and Alphabetical Arrangement of all Imports and Exports at the Port of Dublin, in the Quarter ending the $25^{\text {th }}$ March, 1785, as well as the shipping reports contained in the daily newspapers of the time to create a micro-history of the maritime and mercantile interaction between Ireland and her trading partners. Eaton's "List" not only gives us a complete tally of the goods exported from, and imported into Dublin in the first three months of 1785 but the customs official also recorded the names of each merchant or firm operating in Dublin at that time. This is the first time that such detailed information has been available to scholars and it is unavailable from any other source.

The focus is on Dublin in 1785 and a comparison is made with another Irish port city - Belfast. Change over time is measured by using data for the same focal cities in 1770. Ireland's key market is England and Liverpool is the increasingly popular destination for goods leaving Dublin and the port of lading for goods arriving in Dublin. Using the databases created for the purpose, this thesis analyses the relationship between Dublin/Belfast and Liverpool and discusses the patterns of trade and market structures.

Although every export/import sector had a group of leading merchants, no single merchant or small group of merchants were able to wield sufficient market power to exclude competitors. All sectors of the merchant communities of Dublin, Belfast and Liverpool - regardless of whether they dealt in primary produce, linen products or merchants' goods - were general merchants, with little evidence of specialisation.
\end{abstract}


Irish Maritime Trade in the Eighteenth Century:

A Study in Patterns of Trade, Market Structures, and Merchant Communities

Karen A. Cheer 


\section{Table of Contents}

Abstract

(i)

Table of Contents

Acknowledgements

List of Illustrations, Maps and Tables

Introduction

Chapter One

Richard Eaton's "List"

Chapter Two

Patterns of Trade and Market Structure

Ireland's "Provisioning" Trade with England through the Port of Liverpool

Chapter Four

The Merchant Communities of Dublin, Belfast, and Liverpool

Conclusion

Appendices

Bibliography 


\section{Acknowledgements}

My very sincere thanks to my supervisor, Dr Stephen D. Behrendt, for his generosity - time and knowledge, encouragement and support - all given without hesitation throughout my studies and also to Professor Donald MacRaild who co-supervised until October 2006 when he took up a position at the University of Ulster.

Thank you also to the Wellington Branch of the New Zealand Federation of Graduate Women for financial assistance that enabled me to undertake my Master of Arts by thesis studies. Without their assistance I would not have been able to follow my passion.

Without a grant from the Robert \& Kezia Chapman Trust, administered by the Dublin Meeting of the Religious Society of Friends (Quakers), Dublin, I would not have been able to visit the repositories in Dublin, Belfast and Liverpool; I shall always be grateful for the opportunity I was given. Thank you to the volunteers from the Historical Committee of the Dublin Meeting, Religious Society of Friends, who so ably act as custodians of the resources of the Quaker Library in Stocking Lane, Dublin and who made me feel very welcome. I regret that my final manuscript does not fully utilise all the material I gathered about the Quaker merchants, but I do intend to use the material elsewhere.

Justin Cargill, Neal Garnham, and John Singleton - thank you for answering my questions and emails, commenting on my work, and encouraging me for the duration of my thesis work.

Thank you also to my cohorts and peers, and my workmates in the School of History, Philosophy, Political Science and International Relations at Victoria University for their camaraderie, gentle cajoling and words of wisdom. Jack, thank you for all your support and encouragement, and for letting me juggle the two projects.

Thank you to the staff of the following repositories: Public Record Office of Northern Ireland (PRONI), Belfast; Queen's University, Belfast — Library and Special Collections; Belfast City Library - Local History Room; Trinity College, Dublin - Early Printed Books section; National Library of Ireland, Dublin; National Archives, Dublin; Dublin City Library \& Archives; Liverpool Hope University History Department, and Shepparton-Worlock Library; Liverpool Record Office; Parliamentary Library, Wellington; Victoria University Library, in particular the inter-loans team and the AV suite personnel, and finally to the various libraries all round the world who have allowed very old (and some not-so-old) books from their collections to come to the other side of the world for me to use.

Most of all, thank you to my son Tristram and my friends for understanding, and to my mother Henrietta Dawn Cheer, from whom I inherited a thirst for knowledge.

9 December 2008. 


\section{List of Illustrations, Maps and Tables}

Illustrations:

1.1 Front cover, Richard Eaton, A Daily and Alphabetical Arrangement

page of all Imports and Exports at the Port of Dublin, in the Quarter ending the $25^{\text {th }}$ March, 1785

1.2 Eaton's "List" - An example: Hides exported from the port of Dublin 10

1.3 Eaton's "List" - Exports: an explanation 11

1.4 Eaton's "List" - An example: Imports into the port of Dublin 28

1.5 Eaton's "List" - Imports: an explanation 29

2.1 The Dublin Custom House near Essex Bridge, $1782 \quad 40$

2.2 Port news, port of Dublin from Freeman's Journal 41

2.3 The New Lloyd's List - vessel movements in and out of ports 48

$2.4 \quad$ Belfast News-Letter banner 53

3.1 Port News, port of Liverpool from the Manchester Mercury 71

Maps:

2.0 North Atlantic Ocean 39

3.0 Liverpool, $1798 \quad 59$

$\begin{array}{lll}4.0 & \text { Dublin, } 1798 & 81\end{array}$

$\begin{array}{lll}4.1 & \text { Belfast, } 1791 & 81\end{array}$

Tables:

$\begin{array}{lll}1.1 & \text { Country or region of destination } & 12\end{array}$

$\begin{array}{lll}1.2 & \text { Port of destination in England } & 14\end{array}$

$\begin{array}{ll}1.3 & 15\end{array}$

\begin{tabular}{ll}
1.4 & Port of destination in Europe \\
\hline
\end{tabular}

1.5 Port of destination in the American Colonies 17

1.6 Exports from Dublin, analysed by commodity 20

1.7 Country or region of lading of imports into Dublin 33

1.8 Ports of lading in England 34

1.9 Dublin imports: ports of lading in Europe 36

$2.1 \quad$ Vessel movements out of Dublin, $1785 \quad 42$

2.2 Revised results — vessel movements out of Dublin, $1785 \quad 43$

2.3 Revised results - vessel movements out of Dublin, $1770 \quad 45$

2.4 Abstract of export values, 1770-1800 47

2.5 Vessel movements into Dublin, 1785

2.6 Vessel movements outwards, Belfast, 1770 and 1785

2.7 Vessel movements outwards from Belfast in 1785 compared with vessel movements outwards from Dublin, 1785 
Tables, continued:

2.8 Commodities despatched from Belfast, 1770 and 1785

2.9 Vessel movements inwards, Belfast, 1770 and 1785

2.10 Vessel movements into Belfast, 1785 compared with vessel movements into Dublin, 1785

3.1 Provisions exported from Ireland, 1770-1790 61

3.2 Percentage of total imports into England 62

3.3 Liverpool: consignments arriving from Ireland stated in percentages Comparison 1770 with 1785

3.4 Value of exports and imports, Ireland and England, $1700-1800$

3.5 Increased exports from Ireland to Great Britain, 1770-1790 64

$\begin{array}{lll}3.6 & \text { All shipping movements into Liverpool, } 1785 & 72\end{array}$

3.7 Vessel arrivals in Liverpool from Belfast, $1785 \quad 74$

3.8 Vessel arrivals in Liverpool from Dublin, 1785

4.1 Concentration ratios, exports of butter and linen cloth from Dublin to all destinations in the first quarter of $1785 \quad 108$

4.2 Liverpool: summary of butter market concentration ratios for 1770 and 1785

4.3 Liverpool: summary of quantities of butter imported from Ireland by port of lading, 1770 and 1785

4.4 Liverpool: summary of quantities of linen cloth imported from Ireland, by port of lading, 1770 and 1785

4.5 Summary of linen cloth market concentration ratios for 1770 and 1785

4.6 Concentration ratios, 1785 compared for butter and linen 


\section{Introduction}

Ireland has a centuries-long history of maritime and economic interaction with Great Britain and other more distant communities on the Atlantic rim. Until relatively recently, however, historians have avoided anything other than rudimentary analysis of Ireland's maritime economic history. Instead they have focussed on the social and political history of the country with large numbers of books written on the Irish Diaspora, the Act of Union 1801, and the nineteenth century famine. As a consequence very little is known, other than brief summaries and annual totals, of the composition of the shipments of goods, market structures or the communities of merchants who facilitated the exports and imports of Ireland in the eighteenth century.

In the last forty years of academic writing on the main themes of Ireland's economic history, very few historians have examined the late-eighteenth century maritime trade data to remedy this situation. The lack of primary resources such as the original Customs logs or port books has perhaps deterred them from the task, but sources other than those 'mainstream' are extant. One of these 'alternative' sources was located in the Dublin City Library: Richard Eaton's A Daily and Alphabetical Arrangement of all Imports and Exports at the Port of Dublin, in the Quarter ending the $25^{\text {th }}$ March, 1785 (hereinafter referred to as Eaton's "List"). Another of these 'alternative' sources has been readily available but neglected by historians: the shipping reports contained in the daily newspapers of Ireland and Lancashire.

In 1785 customs official Richard Eaton compiled his quarterly return for Dublin. Robert Bell, a Dublin-based printer, factor and broker, intended publishing this document as part of his twice-yearly Alphabetical Register of Imports and Exports, but this publication never eventuated. Eaton already supplied Bell with the information for his 'newspaper' published as the Daily List of Imports and Exports. Bell's refusal to accept that the Daily was a newspaper (and thus liable to stamp duty) led to his prosecution; he lost the case and plans for the Alphabetical Register were abandoned. This left Eaton's manuscript "List" languishing, therefore, as a 
temporarily bound document. A single copy was located by this author in the 'Gilbert Collection' of the Dublin City Library and Archives in 2005.

Eaton's "List" is invaluable because the original sources of the information — the daily Customs logbooks of goods entering and leaving the Port of Dublin no longer exist. As so often is the case with the day-to-day working documents of the civil service, the sheets used by Customs to ascertain and apportion duty payable or redeemable bounties to individual merchants' accounts were not retained and only the aggregate quarterly returns - the CUST15 (Ledger of Imports and Exports, Ireland, 1698-1829) series held at The National Archives, Kew remain. Eaton's document, however, disaggregated the summary returns by listing the Imports and shows the port of lading, the date of clearing customs inwards, the name of the consignee, the quantities and duty payable. The list of Exports details the port of destination, the date of clearing customs outwards, the name of the exporter, the quantities and the duty payable. A comprehensive range of goods is listed. ${ }^{1}$

This thesis is a micro-history of Ireland's maritime trade in the year 1785. It focuses on the activities of two ports: Dublin and Belfast. Although the latter decades of the eighteenth century are usually remembered for the political instability and vulnerability, it was in reality a vibrant economic era, one of progress, expansion and profit. Whereas in the sixteenth century the principal destinations for vessels leaving the port of Dublin were Ireland's closest European neighbours, by the mid-seventeenth century the British colonies of the Caribbean and North American continent featured more prominently. A century later, regular freight and passenger services left Dublin for Barbados, Grenada, Newfoundland, Nova Scotia, Philadelphia, and Charleston, to name but a few of the transatlantic destinations. At the same time, mail, passenger and freight packets plied the narrow stretch of water between the Irish port and destinations in Scotland, Wales and England. The frequency and capacity of these coastal services also increased significantly over time, especially in the latter decades of the eighteenth century.

\footnotetext{
${ }^{1}$ Unfortunately a small section of the imports list is missing; this does not, I believe, affect the integrity of the document.
} 
This author utilised the information contained in Eaton's "List," which details the maritime and mercantile interaction of Dublin - the largest port in Ireland - and its nearest neighbour Great Britain, and the rest of the transatlantic world, for the first quarter of 1785. Eaton's "List" is one of four principal primary sources examined for this thesis. It presents us with a micro-history of Ireland's trade with the outside world; there are details of who organised Dublin's maritime trade, what goods were being transported in and out of Dublin and where those goods were coming from or heading to. Supplementary to the list are the datasets created by this author from information gathered from other contemporaneous sources, in particular, newspapers. The analysis and conclusions reached about this specific timeframe are placed in context by also examining another Irish port Belfast — and with an earlier timeframe, that is, 1770 .

While there are no equivalent documents for Eaton's "List" for any other year, we need not satisfy ourselves with mere summaries or overviews for analytical purposes. While so much information has been lost forever, it is not, however, always essential to have the 'original' documents; Historians simply need to look at alternative sources for the same information and often the events can be re-created. For example, the early port books of Liverpool have not survived but the type of information originally held in those documents can be replicated using extant contemporaneous sources, such as the local newspapers.

Newspapers are valuable primary sources because the shipping news appeared on a bi-weekly or weekly basis in the local editions. The Freeman's Journal of Dublin published information about the shipping movements in and out of the port of Dublin. Printed on a double-sided broadsheet of up to eight pages per issue, the port news appeared as a summary, and this author obtained a good series of data for 1770 and 1785 .

The shipping reports of The Belfast News-Letter detailed the maritime traffic in and out of the port of Belfast. The newspapers appeared twice weekly on a Tuesday and a Friday. Printed at their High Street premises by Henry and Robert Joy, the paper contained advertisements for freight and passengers and advised of sailing deadlines for vessels bound for the American and Canadian colonies as well 
as those to the West Indies. The names of all vessels 'arrived' at the port and 'cleared outwards' from the port, along with the names of their masters, the last ports of lading or destinations, and type of cargo they carried appeared regularly on page three. Public notices, as well as advertisements for merchandise for sale, appeared alongside news from home and abroad. The information occupied most of the columns of the last two 'pages' of the double-sided broadsheet, while the front two 'pages' kept its subscribers abreast of the latest political and military news.

Published weekly on a Friday, the Liverpool General Advertiser: or, The Commercial Register was the second of Liverpool's main newspapers. It dealt, in the most part, with the social and political happenings in London and with the arrivals at, and departures from, the Port of Liverpool, and later the port at Lancaster. However, a full series of this paper has not survived in good condition. Instead the information contained in the shipping reports of the Manchester Mercury E Harrop's General Advertiser (hereinafter Manchester Mercury), which was published twice weekly, on a Tuesday and Friday, was used for the purposes of this thesis. A comparison of the text of the shipping information in the Liverpool General Advertiser confirms that the Tuesday issue of the Manchester Mercury contains exactly the same information as published on the previous Friday in the Liverpool General Advertiser.

The importance of the shipping information presented in the Liverpool General Advertiser and Manchester Mercury, however, lies with the amount of detail included in the reports. Along with the usual information of the name of the vessel and the name of the master, the arrivals include a list of the quantities and types of goods unloaded as well as the name of the consignee or agent receiving the goods. For each individual year examined for the purposes of this thesis, it is possible to know who in Liverpool purchased what types of commodities and in what quantities from which areas in Ireland. Specialisation by some merchants in certain commodities and other types of trading patterns, such as seasonal patterns, emerged.

The detailed information contained in those lists of goods arrived in Liverpool from Ireland enabled some data matching. A small number of entries for goods 'cleared outwards' from Dublin and Belfast ports matched 'arrivals' reported 
at Liverpool. Several departures from Liverpool bound for Ireland matched arrivals at the Irish ports, as reported in their respective newspapers. It became clear that multiple voyaging took place and it was possible to track the movements of vessels traversing the maritime highway between Ireland and Liverpool, revealing information such as the number of vessels, the duration of the journey and the frequency of those movements. There is some explicit evidence of 'step voyaging' in exports, that is, a vessel left Ireland, called at Liverpool, and then journeyed on elsewhere. There is also some implicit evidence of 'step' voyaging in imports, that is, goods that clearly do not originate from the last port of lading appear as landed goods in Ireland.

For the purposes of this thesis, the author crosschecked information in the shipping reports, wherever possible, to multiple sources. In order to confirm the correct spelling of the vessel names, masters, and the timing of the voyages, information was collated from New Lloyd's Lists and Lloyd's Register, long considered authoritative sources for maritime history. The 'Naval Office Shipping Lists' for the destinations in the British colonies of the Caribbean were checked to verify the information. Also, throughout the eighteenth century, different authors, with varying degrees of expertise, compiled weighty tomes filled with facts and figures on Ireland's 'present state'. Their reports continue to provide us with insights into the economic, social and political condition of the peoples of Ireland.

The records for the year 1785 are the most comprehensive. Not only do we have Eaton's "List" for the first quarter, but there is a full set of shipping reports available for the ports. The year 1785 is also important as the economies and trade patterns had, by this time, re-stabilised following on from the years of turmoil of the American 'War of Independence'. The earlier focal year of 1770 was chosen for three reasons. Many historians consider 1770 to be the year in which a more modern, progressive Ireland began to emerge. It is also a year of relative trade and economic stability; specifically it is pre-American Colonial Independence and post-Seven Years' War. Finally, it is fifteen years earlier than 1785 - the year for which there remains the most comprehensive data. The records for all three focal ports remain 
intact for this year, as do many for the consignee and lading ports in the Atlantic world.

The first historians who studied Irish economic and maritime history in the eighteenth century relied on summaries of the Customs Ledgers, and annual data presented in the Sessional papers tabled in Parliament. Alice Effie Murray ${ }^{2}$ wrote her thesis "A history of the Commercial Relations between England and Ireland from the period of the Restoration" at the London School of Economics in 1903. Miss Murray was praised for producing a study of the "concrete conditions" in preference to "the pursuit of abstract principles which have no relation to any particular country". ${ }^{3}$ She examined English and Irish manuscripts, utilised all available materials from books and documents, and reached the conclusion that the commercial and financial relations between England and Ireland, specifically England's commercial policy with regards to Irish trade, led to "the political and religious upheavals and ultimately the misery of the Irish peoples." Miss Murray's thesis provided an economic explanation for the current [1903] social ills of Ireland.

Recent works by L. M. Cullen and Thomas Truxes have placed pre-1800 Irish history in wider economic and global context. Examining official and unpublished manuscript records, Cullen's 1968 book Anglo-Irish Trade, 1660-1800 focussed not only on the commercial relationship between England and Ireland but placed it in context of total exports, imports and markets. Truxes' Irish-American Trade, 16601783, (1988), arguably the most important recent study, placed Irish trade in Atlantic context. Truxes concluded that Ireland's transatlantic "trade was limited in scale and scope, but it allowed a means of exploiting advantages of geography and

\footnotetext{
2 Alice Effie Murray was born 21 October 1877 at Shillong, Assam in India. She was the daughter of Thomas John Murray of the Indian Civil Service and A.L. Gaussen. Initially home-schooled in India, she also attended the Ladies' College, Guernsey, for five years and Cheltenham Ladies' College for one year. She came up to Girton College (Cambridge) in the Easter term of 1897 to read History (Part I Class III 1899) changing to Moral Sciences in 1899 (Part II Class I 1901). She was awarded the Therese Montefiore Memorial Prize in 1902. In 1903 she obtained a DSc from London University, became a Fellow of the Royal Historical Society, published her thesis and then married Charles Albert Radice on 4 November 1903. She died 3 April 1951. Information received from the Archivist (Kate Perry), Girton College, 8 November 2005; International Genealogical Index (IGI) christening record Alice Effie Murray, daughter of Thomas James [sic] and Alice Louisa Murray, born 21 October 1877, christened 6 January 1878, Shillong, West Bengal, India; Batch ref: C750272, Date 1878, Source 0510855.

${ }^{3}$ W.A.S. Hewins, 'Preface', in E.A. Murray, A History of the Commercial Relations between England and Ireland from the period of the Restoration, London, 1903 (reprinted New York, 1970), p.ix.
} 
resource allocation, thus leveraging growth." 4 His careful examination of primary resources, including Atlantic colonial shipping lists and the business papers of key merchants, revealed just how important Ireland's maritime and economic interaction with the West Indies and North America was to their respective economies.

The revisionist and specialist histories of Ireland, published by the score in the last fifteen years, have shed new light on wider political and economic trends but there is still a major gap in our knowledge about the intricacies of Ireland's eighteenth century maritime and mercantile history.

No scholar has used Eaton's "List" as the basis for analysis, as evidence of trading relationships or as support in the debate surrounding Ireland's image as a struggling economy in the latter half of the eighteenth century. Little use has been made of newspapers other than for studying social or political history; economic or business histories have largely neglected the market reports, the trade advertisements, and the shipping reports. Those historians studying the shipping movements in and out of the port of Liverpool have focussed on the slave trade. By focusing on wider Atlantic trades, historians have under-played the importance of regional trading links between specific Irish ports and those in England or continental Europe.

This thesis, therefore, will present a micro-history of Irish maritime trade, with a commentary on the patterns of trade, market structures and merchant communities. There are four chapters. The first is a discussion and detailed analysis of Eaton's "List" of imports and exports from Dublin in the first quarter of 1785. Evidence of patterns of trade and market structures, discovered when information from other extant documents was used to expand the database to cover the whole of 1785 , is presented in Chapter Two. Chapter Three is concerned with the facts and figures of Ireland's provisioning trade with England through the port of Liverpool and Chapter Four studies the merchant communities of Dublin, Belfast and Liverpool.

\footnotetext{
4 Thomas M. Truxes, Irish-American Trade, 1660-1783, Cambridge, 1988, p.252.
} 


\section{Chapter One: Richard Eaton's "List"}

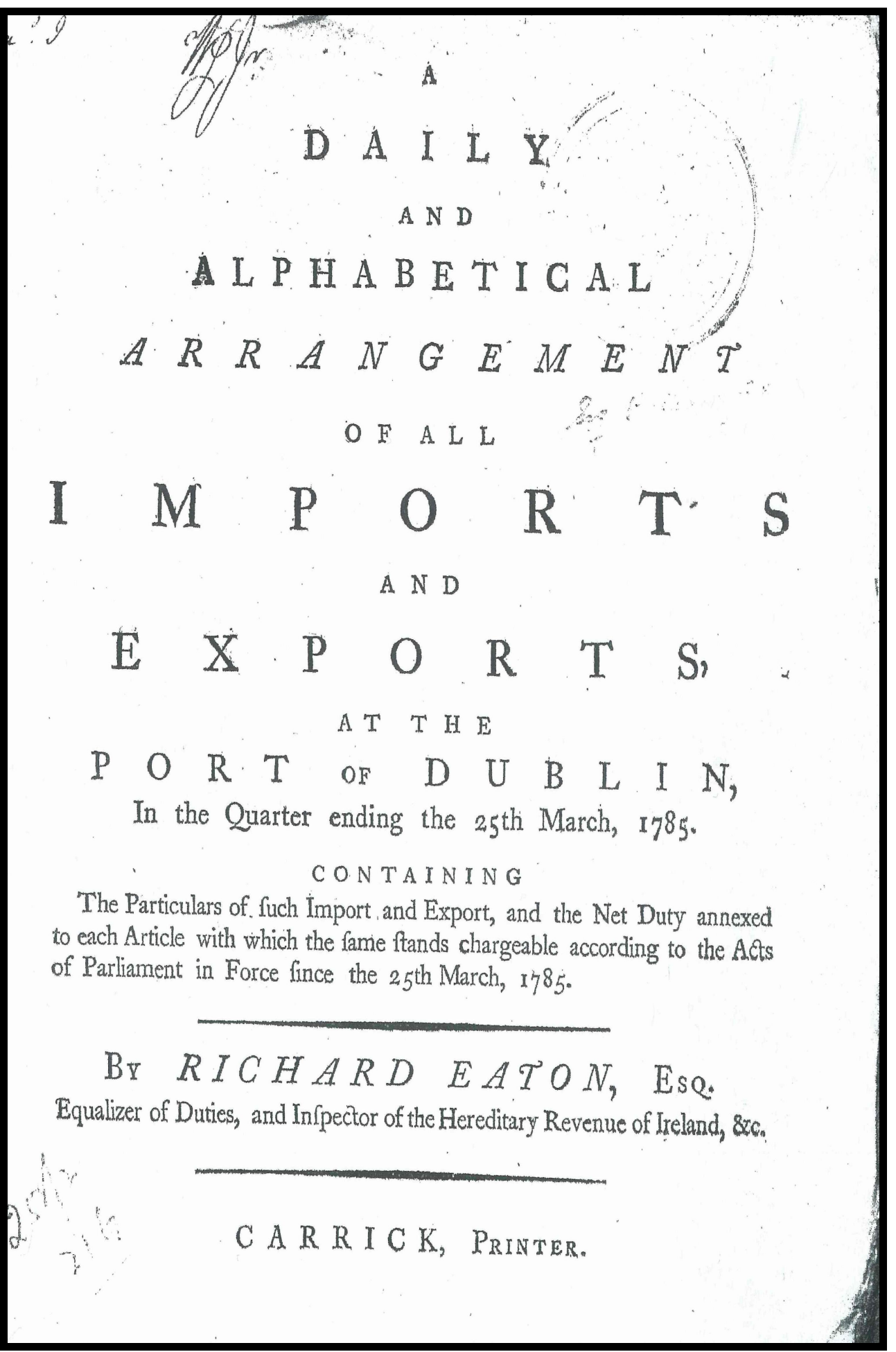

Illustration 1.1: Front cover, Richard Eaton, A Daily and Alphabetical Arrangement of all Imports and Exports at the Port of Dublin, in the Quarter ending the 25 ${ }^{\text {th }}$ March, 1785, Dublin, 1786. Reproduced with written permission from Dr Máire Kennedy, Divisional Librarian, Special Collections, Dublin City Public Libraries. 
Of all the ports of Ireland operating in the eighteenth century, Dublin was by far the largest and busiest. In the sixteenth century, the principal destinations for vessels leaving the port of Dublin were Ireland's closest European neighbours. By the midseventeenth century, the British colonies of the North American continent and the Caribbean featured. All the while the number of mail, passenger and freight packets that plied the narrow stretch of water between the Irish ports and destinations in Scotland, Wales and England steadily increased. In the latter decades of the eighteenth century regular freight services departed Dublin and arrived in Liverpool. The frequency and capacity of these coastal services increased significantly over time as did Ireland's provisioning trade with England.

As part of his daily duties, the Dublin harbourmaster logged vessel movements in and out of the port, and the officers of the Customs house kept daily records of the imports and exports of goods for the purpose of ascertaining duties payable. These detailed records no longer exist. However, Richard Eaton's working life began and ended with the Customs Service. By 1780, he held the post of "Collector of the Port of Dublin" and six years later he was the "Equalizer of Duties and Inspector of the Hereditary Revenue of Ireland." 5

Richard Eaton's “List" of Dublin's imports and exports for January to March 1785 is the most detailed evidence of the maritime and economic interaction of Ireland and the rest of the world that we have for the early modern period. ${ }^{6}$ In this

\footnotetext{
${ }^{5}$ Richard Eaton, born 1746, son of Matthew and Mary Eaton, married Lydia Lord 1767, died Richmond, Co. Dublin, 1789; Biographical information supplied by George Eaton, great-great-great-grandson of Richard Eaton and author of an article about the family published in the 'Newsletter of the Eaton Families Association,' October, 2005. Richard Eaton completed his education at Trinity College, Dublin - the alma mater of his father Matthew and his uncle (also named Richard Eaton). After leaving Trinity he began working for the Customs Service. Early in his career Eaton compiled a volume titled $A$ book of rates, inwards and outwards: with the neat-duties and drawbacks payable on importation and exportation of all sorts of merchandize...; the Customs Office published the work in 1765 and distributed it as a reference text to its offices throughout Ireland. Richard Eaton was only 19 years old at the time and clearly he already excelled in data collation and presentation in standardised form. When he died in 1789 his obituary described the loss of "a gentleman most universally lamented by a numerous acquaintance." Walker's Hibernian Magazine, Vol. XVI, July 1789, Dublin, p.392.

${ }^{6}$ Physically the "List" is small; each page measures $165 \mathrm{~mm}$ wide and $205 \mathrm{~mm}$ high. There are no page numbers but there are binding "signatures" or "gatherings" and each signature contains eight pages. The signatures commence with " $\mathrm{A}$ " and end with the first sheet of what would have been signature " $U$ " if there had been enough pages for a complete signature; the letter " $\mathrm{J}$ " is not used and signature " $\mathrm{P}$ " is missing. Originally there would have been 160 pages in the document. Catchwords appear on the bottom of the pages. The lone copy was located in the Gilbert Collection, Dublin City Public Libraries. Dublin Corporation purchased John T. Gilbert's valuable library of mainly 17th and 18th
} 
chapter, the text of the document is examined and annotated to create a microhistory of Dublin's economic history in the first quarter of 1785. The exports from the port are discussed in the first section and imports in section two. The marked difference in the categories of goods that make up the list of exports and imports becomes obvious immediately and the analysis of the information reveals certain patterns of trade.

\section{Illustration 1.2: Eaton's “List" - An example: Hides exported from the port of} Dublin

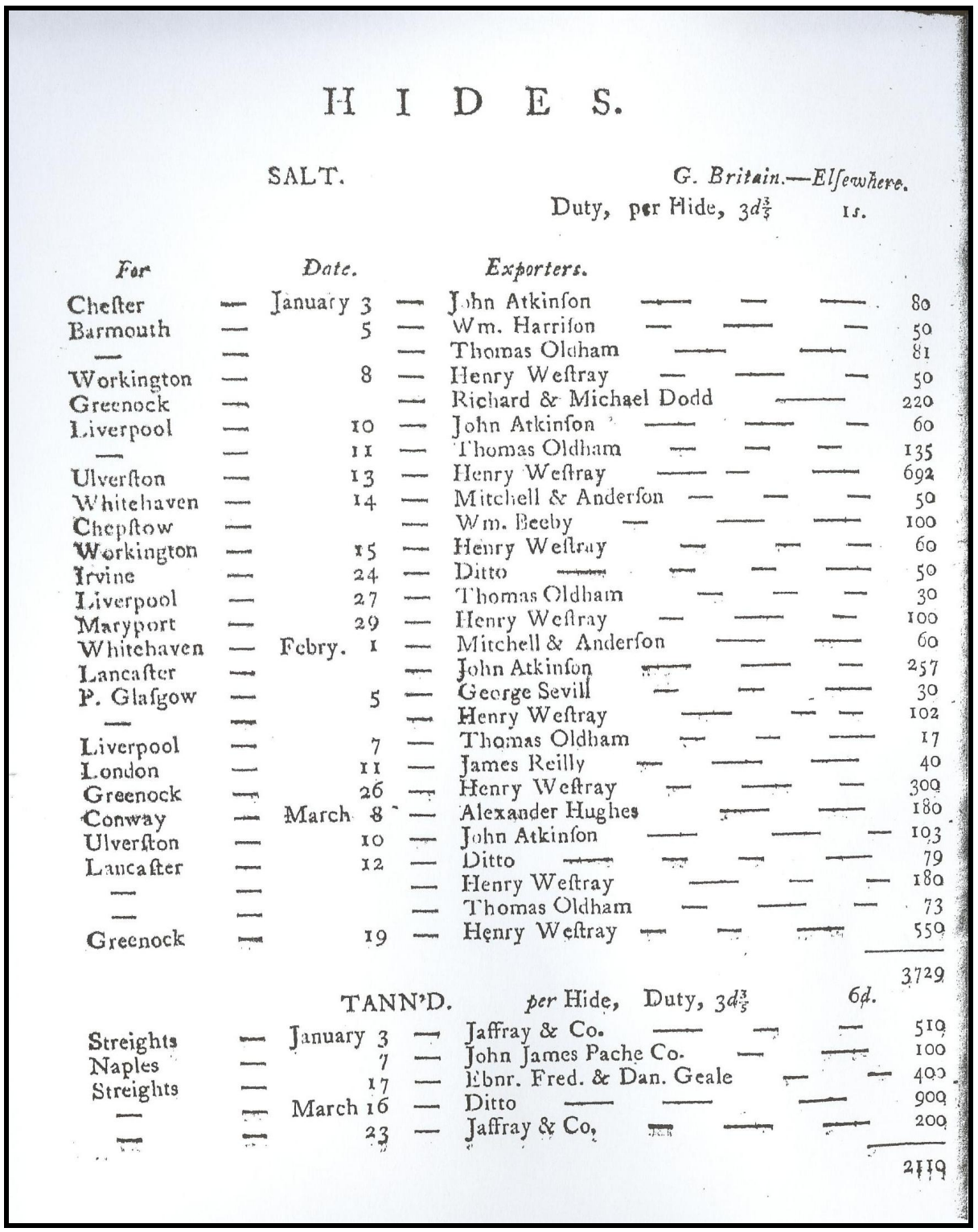

Illustration 1.2: Reproduced with written permission from Dr Máire Kennedy, Divisional Librarian, Special Collections, Dublin City Public Libraries.

century books and manuscripts relating to Dublin and Ireland after his death in 1898. It forms the nucleus of the special collections section of Dublin City Public Libraries 
In the absence of the original working documents, Eaton's "List" is a credible substitute. In this first section of the chapter we examine the text of the "List" in relation to the exports leaving the port of Dublin in order to analyse patterns of trade and market structure. The exports are listed as individual consignments from individual exporters or merchants; it is therefore important to note that for the purposes of this thesis, and specifically the analysis of Eaton's "List", a consignment is defined by this author as 'one quantity of one commodity supplied by one exporter and despatched on one day' or 'one quantity of one commodity imported by one importer and cleared through Customs on one day. ${ }^{7}$

Illustration 1.3: Eaton's “List” - Exports: an explanation

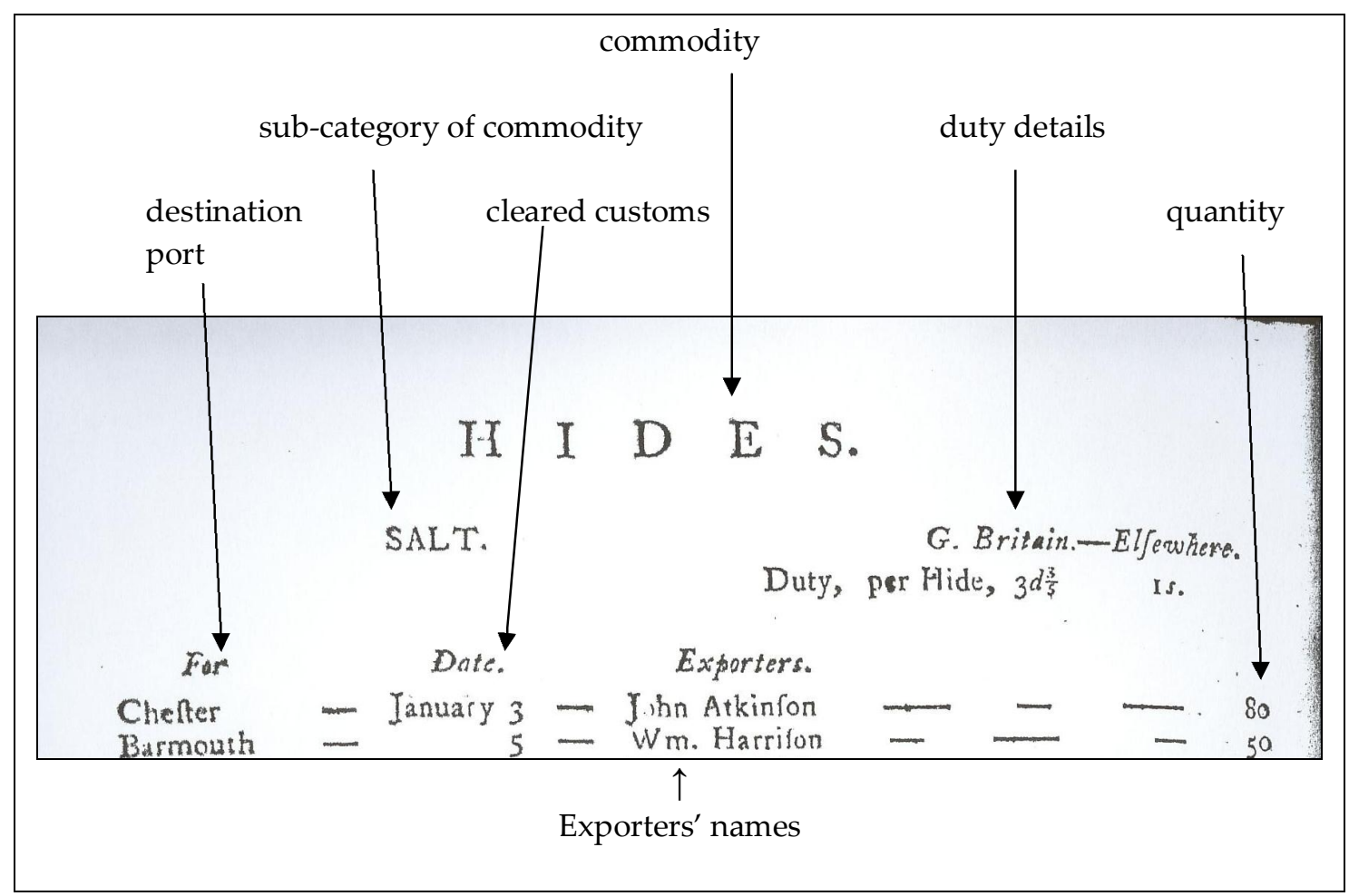

\footnotetext{
${ }^{7}$ As there is no information about the number of vessels involved in the transportation of the goods to or from their destinations, it would be incorrect to refer to each 'consignment' as a shipment.
} 
There are, in total, 462 individual consignments listed as exports from the port of Dublin for the period from Christmas Day (1784) to Lady Day (25 March) 1785. ${ }^{8}$ The first column of information in the exports "List" is that of the port of destination. Of all the consignments leaving the port 64.7 percent (or 299 consignments) were destined for ports in England, 19.5 percent (90) for Scotland and 0.4 percent (2) for Wales. The remaining 15.4 percent (71) were despatched to ports in Europe, with France and Spain the leading recipients, and the American Colonies of the north Atlantic rim was the next ranked destination (see Table 1.1).

Table 1.1: Country or region of destination

\begin{tabular}{|l|c|c|}
\hline \multicolumn{1}{|c|}{ Country/Region of Destination } & No. of Consignments & $\begin{array}{c}\text { \% of total number of } \\
\text { consignments }\end{array}$ \\
\hline England & $\mathbf{2 9 9}$ & $\mathbf{6 4 . 7 \%}$ \\
\hline Scotland & $\mathbf{9 0}$ & $\mathbf{1 9 . 5 \%}$ \\
\hline Europe & 35 & $7.6 \%$ \\
\hline American Colonies & 31 & $6.7 \%$ \\
\hline Caribbean & 5 & $1.1 \%$ \\
\hline Wales & 2 & $0.4 \%$ \\
\hline & $\mathbf{4 6 2}$ & $100.0 \%$ \\
\hline
\end{tabular}

Source: Eaton's “List”

Merchants in English ports received nearly two-thirds of all of Dublin's exports, confirming contemporary comments about the importance of the English market. Works by Macartney (1773), Whitworth (1776), and Laffan (1785) all support this statement; each cites England as the key market for Irish exports. Similarly, modern authors such as Murray (1903), Schumpeter (1960), and Cullen (1968) also cite England as the key market.

Eaton's "List," importantly provides unique information about which ports in England received what number of consignments during this time. In the three months to 25 March 1785, 65.1 percent of the consignments despatched from Dublin were destined for England and 41 percent of those were consigned to Liverpool possibly for transhipment to other destinations but most likely for sale in the local

\footnotetext{
8 The quarter or three months of the financial year falls between any of the four dates on which payments such as ground rents became due in England, that is, 25 March (Lady Day), 24 June (Midsummer Day), 29 September (Michaelmas), and 25 December (Christmas Day).
} 
market. Nearly 20 percent of the consignments left Dublin for the second ranked English destination, London. Interestingly, no Dublin vessels were destined for ports in the Northeast of England; no consignments in Eaton's "List" are shown for ports such as Hull, Sunderland, or Newcastle. For the 10,000 people living in Hull in 1785 , it is possible that Irish butter and Irish linen were luxury imports enjoyed only by an elite few.

There are several reasons why Liverpool was the leading destination; although the population (about 75,000 in 1785), and hence the market size, of Liverpool was much smaller than that of London, transport costs from Ireland were less than those incurred in shipping to London. The major component in the price of low-value products is that of transportation. As it usually only took one day travelling time from Dublin to Liverpool compared with a minimum of three days voyaging to London, this would have influenced the choice of destination.

London was the most important of all the English trading ports and there is no doubt that the same products that arrived from Ireland came from other countries and ports and competed with Irish goods, pushing down prices. Another consideration would be the sheer size of a large market such as London, with its population numbering approximately one million in 1785 , which often equates to lower sale prices and reduced profits and so Liverpool would be the more attractive market. Finally, as Lancashire was the key industrial area at this time, Irish provisions were required for the burgeoning population and Liverpool was, geographically, the nearest port. ${ }^{9}$

Liverpool did not completely displace London, as the more distant city retained its market share for traditional as well as commercial reasons. The banking system and financial markets centred on London, and had done so for a long time. Many of the families, especially in the north of Ireland, retained their familial and commercial links to London. Another possible explanation for London's one-fifth

\footnotetext{
${ }^{9}$ Maps of the coastal ports on the English east coast near Lancaster show tidal mud flats and rivers that tend to silt up and this would have precluded their use for large scale maritime activity. Attempts to use Preston, for example, often met with calamity; Lancaster itself was an important port in the seventeenth century but declined in the period when Liverpool began to rise in popularity.
} 
share of the consignments is that the larger and more varied market of London, equated to more exotic return cargoes than those available from Liverpool.

Table 1.2: Port of destination in England

\begin{tabular}{|l|c|c|c|}
\hline $\begin{array}{c}\text { Port of } \\
\text { Destination }\end{array}$ & $\begin{array}{c}\text { No. of } \\
\text { Consignments }\end{array}$ & $\begin{array}{c}\text { \% of total no. of consignments } \\
\text { destined for England }\end{array}$ & $\begin{array}{c}\text { \% of total no. of } \\
\text { Consignments }\end{array}$ \\
\hline Liverpool & $\mathbf{1 2 2}$ & $41 \%$ & $\mathbf{2 6 . 4 \%}$ \\
\hline London & $\mathbf{8 9}$ & $30 \%$ & $\mathbf{1 9 . 3 \%}$ \\
\hline Whitehaven & 23 & $8 \%$ & $5.0 \%$ \\
\hline Bristol & 23 & $8 \%$ & $5.0 \%$ \\
\hline Lancaster & 12 & $4 \%$ & $2.6 \%$ \\
\hline Chester & 6 & $2 \%$ & $1.3 \%$ \\
\hline Yarmouth & 5 & $1.8 \%$ & $1.0 \%$ \\
\hline Workington & 4 & $1.4 \%$ & $0.9 \%$ \\
\hline Chepstow & 4 & $1.4 \%$ & $0.9 \%$ \\
\hline Barmouth & 4 & $1.4 \%$ & $0.9 \%$ \\
\hline Maryport & 3 & $1 \%$ & $0.6 \%$ \\
\hline Ulverston & 2 & $\sim 1 \%$ & $0.4 \%$ \\
\hline n.s. & 2 & $\sim 1 \%$ & $0.4 \%$ \\
\hline & $\mathbf{2 9 9}$ & $100.0 \%$ & $\mathbf{6 4 . 7 \%}$ \\
\hline
\end{tabular}

Source: Eaton's “List”

Ports in Scotland received the second highest number of consignments of goods exported from Dublin. Eaton's figures show that 19.5 percent (or nearly one-fifth) of the total number of consignments for the first quarter of 1785 was destined for one of several major ports in Scotland; 12.6 per cent were due for discharge in Greenock, and Irvine ranked second as a port of destination (See Table 1.3).

There are two reasons why Scotland was the second-ranked destination geography and the availability of return cargoes of tobacco and sugar; the latter will be discussed further in the second part of this chapter when imports into Dublin are analysed. The first reason - geography — explains Scotland as a destination just as it did with England as the main recipient of goods from Dublin. Many of the ports of Scotland were within easy reach of Dublin; Greenock is 162 nautical miles 
(300kms) from Dublin and takes approximately three days sailing time. The limiting factor with Scotland as a market, however, was its population at this time. ${ }^{10}$

Table 1.3: Port of destination in Scotland

\begin{tabular}{|l|c|c|c|}
\hline Port of Destination & $\begin{array}{c}\text { No. of } \\
\text { Consignments }\end{array}$ & $\begin{array}{c}\text { \% of no. of consignments } \\
\text { destined for Scotland }\end{array}$ & $\begin{array}{c}\text { \% of total no. of } \\
\text { Consignments }\end{array}$ \\
\hline Greenock & $\mathbf{5 8}$ & $65 \%$ & $\mathbf{1 2 . 6 \%}$ \\
\hline Irvine & $\mathbf{1 7}$ & $20 \%$ & $\mathbf{3 . 7 \%}$ \\
\hline Rothsay & 4 & $4 \%$ & $0.9 \%$ \\
\hline Port Glasgow & 4 & $4 \%$ & $0.9 \%$ \\
\hline Saltcoats & 4 & $4 \%$ & $0.9 \%$ \\
\hline Dunfries [Dumfries] & 2 & $\mathbf{2 \%}$ & $0.4 \%$ \\
\hline (St)ernaway Total & 1 & $1 \%$ & $0.2 \%$ \\
\hline & $\mathbf{9 0}$ & $100.0 \%$ & $\mathbf{1 9 . 6 \%}$ \\
\hline
\end{tabular}

Source: Eaton's “List”

According to Eaton, Europe and the markets of the now-independent American Colonies received an almost equal number of consignments. The European ports of Alicante, Bordeaux, Campveer, Corunna, Havre, Naples, Oporto, Rochfort, and 'Streights' all appear in the destinations column of the "List." The number of consignments that each port received is small with the highest number for Bordeaux (eight) and 'Streights' (eight). ${ }^{11}$

The trade with Bordeaux dates back many centuries with their merchants keen to obtain Irish beef and butter in return for cargoes of wine. Many of the traders of Bordeaux are descendants of the original 50,000 dissidents exiled during the seventeenth century religious purges, and further waves of migrants in 1715 and 1745. Along with settlements in Bordeaux, Irish expatriates traded from Nantes and Rouen. Most traded in wine and purchased salted meats and textiles, such as linen cloth. ${ }^{12}$

\footnotetext{
10 The population in the 1750s was estimated as $1,265,000$ (with an annual increase in the 1760s of approximately 0.4 percent per annum) and the 1801 census recorded a little over 1,600,000 inhabitants. Rosalind Mitchison, A History of Scotland, London, 1970 (second edition, 1982); my estimate, therefore, is that the population of Scotland was approximately 1,400,000 in 1785.

11 'Streights': it is unclear whether this is the Straights of Messina, off Sicily or the 'Streights' of Gibraltar.

${ }^{12}$ Names such as MacCarthy, Exshaw, Clarke and Barton figure prominently in the lists of traders in Bordeaux. URL: http://www.franceguide.com accessed 3 December 2007.
} 
In an example of possible scenarios for the shipment of the 35 consignments to Europe, the Ann \& Elizabeth ${ }^{13}$ and the Volunteer both departed Dublin, according to New Lloyd's List, for Campveer on 15 February 1785. No other vessels are listed with this destination in the six weeks prior to this date and Eaton lists only one consignment for Campveer - 36 dozen tongues, on a ship clearing 7 February. These vessels may have picked up cargoes of other goods at other ports as certainly one consignment tongues is not an economically viable cargo.

Table 1.4: Port of destination in Europe

\begin{tabular}{|c|c|c|c|}
\hline Port of Destination & $\begin{array}{c}\text { No. of } \\
\text { Consignments }\end{array}$ & $\begin{array}{c}\% \text { of no. of } \\
\text { consignments } \\
\text { destined for Europe }\end{array}$ & $\begin{array}{l}\% \text { of total no. of } \\
\text { Consignments }\end{array}$ \\
\hline Bordeaux, France & 8 & $22.8 \%$ & $1.7 \%$ \\
\hline Streights, Sicily or Gibraltar & 8 & $22.8 \%$ & $1.7 \%$ \\
\hline Rotterdam, Holland & 6 & $17.1 \%$ & $1.3 \%$ \\
\hline Havre, France & 5 & $14.2 \%$ & $1.1 \%$ \\
\hline Campveer, Holland & 3 & $8.6 \%$ & $0.6 \%$ \\
\hline Alicante, Spain & 1 & $2.9 \%$ & $0.2 \%$ \\
\hline Corunna, Spain & 1 & $2.9 \%$ & $0.2 \%$ \\
\hline Oporto, Portugal & 1 & $2.9 \%$ & $0.2 \%$ \\
\hline Rochfort, France & 1 & $2.9 \%$ & $0.2 \%$ \\
\hline Naples, Italy & 1 & $2.9 \%$ & $0.2 \%$ \\
\hline Total & 35 & $100.0 \%$ & $7.4 \%$ \\
\hline
\end{tabular}

Source: Eaton's “List”

Thirty-one consignments destined for ports in the now-independent American Colonies left Dublin in the period defined in Eaton's "List." The earliest of the customs clearances outwards is listed as 22 February and the latest as 16 March, 1785; again it is quite possible that these consignments were all despatched on one vessel with multiple destinations in the former colonies. ${ }^{14}$ The size of the vessels on

\footnotetext{
${ }^{13}$ Captained by J. Allen, the brig Ann E Elizabeth was built in Hull in 1767 and carried a second-rate certification of E1 when surveyed in April 1789. The 160-ton vessel was owned by a Whitehaven partnership, according to Lloyd's List, 1790. There are only two listings for vessels with this name in 1790; it is not possible to ascertain which of the two entries the correct one for this 1785 event is. ${ }^{14}$ The Freeman's Journal of Dublin has no reports of a vessel departing for the now-independent American Colonies within a reasonable time of these customs outwards clearances. It is possible that one of the 'unspecified' destinations is in fact a port on the eastern seaboard. An unnamed vessel is listed as departing for Baltimore on 11 April 1785 and as none of the goods in the consignments were perishable, it is possible that the departure was delayed until further cargo was found.
} 
this route, some of which were 300 to 400 tons burthen weight/displaced tonnage, allowed large quantities of goods to be carried the distance. The Dublin Packet, for example, with a burthen weight of 300 tons regularly travelled between Dublin and Philadelphia.

The Lucy departed Dublin on 11 March with an unspecified cargo for New York with Captain Trousell at the helm. As no other vessel is recorded as departing in the previous weeks, it would be correct to assume that the consignments of linen cloth that cleared customs 22 February, 23 February, 25 February and 28 February all went to New York on that vessel. I am certain that as no other vessels are listed in any publication as destined for Philadelphia that those shipments listed by Eaton (coincidentally clearing outwards on the same days) also went on board the Lucy and the vessel made two calls at ports in the newly-independent American colonies.

Table 1.5: Port of destination in the American Colonies

\begin{tabular}{|l|c|c|c|}
\hline $\begin{array}{c}\text { Port of } \\
\text { Destination }\end{array}$ & $\begin{array}{c}\text { No. of } \\
\text { Consignments }\end{array}$ & $\begin{array}{c}\text { \% of no. of consignments } \\
\text { destined for former } \\
\text { American Colonies }\end{array}$ & $\begin{array}{c}\text { \% of total no. of } \\
\text { Consignments }\end{array}$ \\
\hline Philadelphia & $\mathbf{2 5}$ & $80.6 \%$ & $\mathbf{5 . 4 \%}$ \\
\hline New York & 4 & $12.9 \%$ & $0.9 \%$ \\
\hline Baltimore & 2 & $6.5 \%$ & $0.4 \%$ \\
\hline & $\mathbf{3 1}$ & & $\mathbf{6 . 7 \%}$ \\
\hline
\end{tabular}

Source: Eaton's “List”

The most distant of the markets for Irish goods at this time was the British colonies in the Caribbean; in this instance the only port recorded is Antigua. Numerically only five consignments were despatched from Dublin for this market in the first quarter of 1785 but there is nothing unusual in this as the length of the voyage there and back precluded, in many instances, more than two or possibly three return voyages in a year. For example, the King William left Liverpool with John Butler at the helm in February 1785 bound for Antigua in the Caribbean and was back in Liverpool again in July - a voyage and turnaround time of five months. ${ }^{15}$ The turnaround time for a Dublin/Antigua voyage would normally be the same.

\footnotetext{
${ }^{15}$ From information abstracted from the shipping lists of New Lloyd's List, Manchester Mercury, and Naval Office Lists.
} 
While some of the vessels plying the northern Atlantic destined for the Caribbean from Dublin were in the 300 to 400 ton range, quite often they were smaller vessels such as the Lord Bangor at 100 tons. ${ }^{16}$ In one example, Eaton's "List" shows that the five consignments, consisting of 143 barrels of beef, 220 barrels of herrings, 34 dozen tongues and 675 yards of Linen, cleared customs outwards within three days of each other, that is between 28 January and 1 February $1785 .{ }^{17} \mathrm{It}$ is highly likely that all the consignments listed were sent in one vessel, the 80 ton Goodwill with Captain John Sinnott at the helm which (according to the shipping reports of the Freeman's Journal) ${ }^{18}$ departed Dublin for Antigua on 1 February 1785 with 'goods.'

Having established the key markets for exports from Dublin from Eaton's "List", let us now consider what goods Irish merchants exported. Eaton listed his information by commodity and these fall into three main categories: primary produce and byproducts; linen yarn and linen products; and "merchants' goods." Ireland had a long history of supplying agricultural and animal exports. George (later first Earl) Macartney listed Ireland's exports to Great Britain, in his Account of Ireland in 1773, as: "Linen and linen yarn, wool, woollens, and worsted yarn, copper ore, beef, butter, pork, tallow, oats and oatmeal, rabbits feet and skins, hides, kid, calf, goat, lamb, otter, and fox skins, ox-horns, glue, usequebaugh, feathers, quills, candles, soap."19 In 1776 Whitworth stated that "the articles we [Great Britain] receive from this kingdom [Ireland] are Hides, Linen, provisions, Butter, Cattle." ${ }^{20}$ In 1785, James

\footnotetext{
${ }^{16}$ Lloyd's Register, 1790 ref L227 - Lord Bangor, brig, 100 [tons] [configuration] sdb, [built in] Hull, [17]64, [owners] Boyle\&C; [surveyed] 1790-7, [condition] E2. Lloyd's List: Arrived 9 March in Dublin from Antigua, Captain McCray.

${ }^{17}$ The weight of a barrel or tierce would vary according to the commodity packed into them. They were usually defined by a liquid measure, that is, 1 barrel $=36$ gallons $=158$ litres and if the commodity was water it would weigh $158 \mathrm{~kg}$. Thus a barrel containing meat, which is heavier per gram than water, would weigh $158 \mathrm{~kg}$ as a minimum.

${ }^{18}$ New Lloyd's List also shows the vessel Goodwill departed for Antigua on 1 February 1785 although the 'Naval Office Shipping Lists' return has the brig listed as the Good Intent, which cleared customs inwards at Antigua on 24 March 1785, John Sennot at the helm and carrying 'sundry provisions from Dublin.' There is no reason to not conclude that this is the same vessel.

${ }^{19}$ Earl George Macartney, An account of Ireland in 1773. By a late chief secretary of that Kingdom, London, 1773, p.119.

${ }^{20}$ Charles Whitworth, State of the trade of Great Britain in its imports and exports, progressively from the year $1697 \ldots$ in two parts, London, 1776, part 1, pp.2-3.
} 
Laffan observed primary produce and its by-products, as well as linen, were the mainstay of the Irish economy, both in the internal market and the export trade. ${ }^{21}$

The 'primary produce and by-products' in Eaton's "List" includes beef, hides and skins, butter, bacon, pork, tallow, and tongues. According to Eaton's figures, a total of 3,153 tierces and 2,680 barrels of beef, 4,581cwt of butter, 1,573 barrels of pork and 1,415cwt of tallow left Dublin during the quarter; beef made up 18.6 percent of the consignments, butter 8.0 percent, pork 5.6 percent, and tallow 3.2 percent. Bacon Flitches and Bacon Hams numbered 2,888 and 2,033 respectively or 6.5 percent of all consignments. ${ }^{22}$ Hides (salted or tanned) and skins, by-products of the slaughter of beef for export, totalled 5,839 (3,729 salted and 2,110 tanned) and 1,504 dozen respectively and 18,763 ox horns were also exported to a variety of markets - 6.9 percent, 5.4 percent, and 1.3 percent, as a percentage of the total number of consignments. A total of 265 consignments, or 57.4 percent of the total number of consignments, are 'primary produce and by-products' (see Table 1.6).

In the second category - 'linen yarn and linen products' - a little over 270,000 yards of bounty linen cloth was exported to the American Colonies and a further 7,918,911 yards of non-bounty linen cloth was sent to a few European ports. The overwhelming majority of the product was shipped to ports in England, Scotland and Wales. Linen yarn and linen products represent 27.5 percent of the exports (see Table 1.6). From the table, we know that the first two categories alone account for 84.9 percent of the total number of consignments exported from Dublin.

The category 'merchants' goods' includes miscellaneous goods such as $129 \mathrm{cwt}$ of barilla ashes and 20cwt of glue destined for London, 526 dozen silk handkerchiefs exported to Philadelphia, and 500lbs of indigo (undoubtedly Carolina-produced) sent to London. In total, merchants' goods represent about 15 percent of the total number of consignments exported from Dublin.

\footnotetext{
${ }^{21}$ James Laffan, A Political Arithmetic of the Population, Commerce and Manufactures with Observations on the Relative Situation of Great Britain and Ireland, Dublin, 1785.

${ }^{22}$ A 'flitch' of bacon is one half of the animal split from head to tail. The weight of a flitch varied depending on the size of the pig. The following is the only reference found to the weight of a flitch of bacon: In 1810 Nicholas Lowe appeared before the Devon Quarter Sessions for "feloniously stealing a Flitch of Bacon about thirty pounds weight." URL: http://genuki.cs.ncl.ac.uk/DEV/CourtRecords/QS3287.html, accessed 3 December 2007; $1 \mathrm{cwt}=112 \mathrm{lbs}-50.8 \mathrm{~kg}$.
} 
Table 1.6: Exports from Dublin, analysed by commodity

\begin{tabular}{|l|c|c|}
\hline \multicolumn{1}{|c|}{ Commodity } & $\begin{array}{c}\text { No. of } \\
\text { Consignments }\end{array}$ & $\begin{array}{c}\text { \% of total number of } \\
\text { consignments }\end{array}$ \\
\hline Main categories: & & \\
\hline Primary Produce \& By-products & 265 & $57.4 \%$ \\
\hline Linen yarn \& Linen products & 127 & $27.5 \%$ \\
\hline Merchants' goods & 70 & $15.1 \%$ \\
\hline Total & $4 \mathbf{4 6 2}$ & $\mathbf{1 0 0 . 0} \%$ \\
\hline Key commodities: & & $18.6 \%$ \\
\hline Beef (tierces and barrels) & 86 & $15.8 \%$ \\
\hline Linen (cloth) & 73 & $12.3 \%$ \\
\hline Hides and skins & 57 & $11.7 \%$ \\
\hline Linen (yarn \& great stones) & 54 & $8.0 \%$ \\
\hline Butter (cwt) & 37 & $6.5 \%$ \\
\hline Bacon (flitches \& hams) & 30 & $5.6 \%$ \\
\hline Pork (barrels) & 26 & $3.2 \%$ \\
\hline Tallow (cwt) & 15 & $3.0 \%$ \\
\hline Tongues (dozen) & 14 & \\
\hline
\end{tabular}

Source: Collated by this author from information contained in Eaton's "List"

Let us now consider what quantities of these Irish goods were exported to the various English ports. In the case of the key commodity beef, of which 86 consignments were shipped from Dublin, 48 consignments, or 55.8 percent of the total, went to English ports. ${ }^{23}$ Expressed in terms of the percentage of the total volume of beef exported, England received approximately 50 percent of the volume of goods whether shipped in barrels or tierces, that is, 1,173 of the 2,680 barrels of beef shipped and 1,593 of the 3,153 tierces of beef shipped. Of the leading ports, Liverpool received 12 consignments and London 22 consignments of beef.

One of the key by-products of the slaughter of farm stock is the pelts of the animals. Because Ireland raised and slaughtered so many farm animals the skins industry thrived - especially in the wake of increased demand for shoe leather and the expansion of the book bindery sector. ${ }^{24}$ Of the 57 consignments despatched from

\footnotetext{
${ }^{23}$ The remaining 26 consignments ( 30 percent) went to Scotland, 9 to Europe (10.5 percent), 2 to the now-independent American colonies and one to the Caribbean. These latter two markets only received a total of 3.5 percent of the consignments.

${ }^{24}$ Furs, such as fox, otter and hare skins were not classified as a sub-category of 'hides \& skins' but listed separately. They would have been utilised by the fashion industry.
} 
Dublin, 40 consignments or 70.2 percent of the total number of consignments went to English ports.

Within the category of 'hides \& skins' the figures do reveal variations of market share, and seemingly a degree of market specialisation, according to the product. For example, all of the 2,110 tanned hides were exported to European markets; no tanned hides went to English ports. In the case of the salt hides, 21 consignments (or 78 percent) went to England, with one consignment for London and the other four destined for Liverpool. Eight of the 14 consignments (57 percent) of calf skins went to England - five of which went to Liverpool and none of which were offloaded in London. Overall, by far the largest number of the hides and skins went to England whether measured by number of consignments or by volume/quantity of goods.

All eleven consignments of the 'Kips \& Runners' were destined for English ports, according to Eaton. A total of 996 dozen of the untanned calf skins (Kips) included one consignment of 360 dozen while several others contained only five dozen skins. Again Liverpool received the largest number of consignments and the largest quantity of the commodity in question. Any of the small vessels plying the sea between Dublin and the English ports - most of which were between ten and twenty tons burthen weight - could have carried even the largest of the consignments of this commodity without difficulty whereas some of the large consignments of pelts from the fully-grown animals would have been high volume as well as weight.

The key commodities of butter, bacon, pork, tallow and tongues, each with ten percent (or less) of the total number of consignments, complete the list of constituents of the main category of 'primary produce and by-products.' The figures for butter exports show that 37 consignments totalling 4,581cwt left Dublin in the first quarter of 1785 . Of the 26 consignments to England, many were less than $20 \mathrm{cwt}$; approximately 70 percent by number and volume went to England, with wide variations in the quantity of goods in each individual consignment. Five consignments went to Liverpool and 14 to London. 
Although the beef farmers dominated the agricultural sector, pig farming was not insignificant, and along with cured flitches and hams, the export of barrels of pork represents 5.6 percent of the total number of export consignments from Dublin in the first three months of 1785. Once again England and Scotland are the only markets shown in Eaton's "List." Only a little over five percent of the number of consignments was exported to Scotland; the English ports are listed as the destination for 1,501 full barrels and one half barrel. Six consignments went to Liverpool and nine to London. There are no shipments to European ports listed.

While 15 consignments of bacon flitches were despatched to ports in England, only one consignment went to Greenock, Scotland. That one consignment of 211 flitches despatched to Scotland, equals six percent of the market share by number of consignments but slightly less than ten percent of the market share by volume of goods. The English markets took 2,677 bacon flitches in 15 consignments being 94 percent of the consignments of the commodity and a little over 90 percent of the volume of the commodity. In the case of the bacon hams ten shipments were sent to English ports and four to Greenock. Eaton's "List" shows the quantity of flitches measured in units while the hams are measured in a mixture of units and weight, specifically hundredweights (cwts), quarters (qrs) and pounds (lbs). It is difficult, therefore, to carry out the same type of analysis and to quantify any differential between the percentage of market share for the number of consignments and the percentage of market share by volume of goods.

Tallow is the rendered fat from slaughtered animals; it was principally used for making candles and soap, and for dressing leather. According to Eaton, 1,415cwt of tallow was despatched in 15 consignments, 14 of which went to English ports and one to Greenock, Scotland. The dominance of the English market is clear yet again, with over 93 percent of the number of consignments and an equal proportion of the volume of goods going to ports within easy sailing of Dublin. Seven of the shipments were despatched to Liverpool and two to London.

In the last of the by-products analysed from Eaton's "List", consignments of tongues represent only three percent of the total number of consignments despatched from the port. A total of 286 dozen tongues was sent in 14 consignments 
were exported with six consigned to English ports; they represent approximately 43 percent of the number of consignments and 42 percent of the quantity of tongues exported. An equal number of consignments went to London and Liverpool, that is, three consignments each.

Numerically, exports of primary produce and by-products equal 57.4 percent of the total number of consignments that cleared customs outwards from the port of Dublin during the months under examination. As a multiplicity of commodities, each with their own unit of measurement of volume, were despatched it is not possible to quantify the percentage of the total volume of goods represented. For example, a total of 1,573 barrels of pork were exported and 2,680 barrels of beef left Dublin; it is not possible to calculate the percentage of total volume of exports each represents and in the absence of a value for the commodities, a percentage of value is not available.

However, in the analysis of individual commodities in this main category, it has been possible to show which markets received what proportion of the volume of goods as well as quantifying the proportion of the number of consignments. While there are significant variations in the volume of individual consignments for some of the commodities, in only a very few instances has this author found a noticeable variation between the percentage of consignments and percentage of 'volume' of goods as indicators of market share.

As enumerated in Table 1.6, the second largest category of consignments exported from the port of Dublin was 'Linen yarn \& Linen cloth'. Linen cloth consignments made up the larger percentage of the total number of consignments at 73 consignments (15.8 percent) and linen yarn only 11 percent (41 consignments). The 73 consignments of linen cloth are divided into consignments for 'bounty' and 'not for bounty.' The bounty was introduced in 1743 as an incentive to Irish linen manufacturers to produce more of the brown or coarse linens to supply the needs of plantation owners. It was an attempt to dominate that market which, at the time, was inundated with German linens.

Payment was made to the exporting merchant whose linen was destined for English ports for re-export to the former colonies or the British Caribbean 
settlements. The bounty was paid on the quality and price of the linen and worth either one halfpenny or one penny per yard. Further amendments and revisions to the original act occurred in 1745 and $1770 .{ }^{25}$ From Eaton's figures it appears that the majority of Dublin's exports of linen in this first quarter of 1785 did not meet the criteria, that is, they were of superior quality and thus ineligible for the half-penny per yard bounty that applied to the brown or coarse linen cloth.

There are 16 consignments of "linen for bounty" listed, all of which, bar one consignment, went to the now-independent American colonies. Ten were despatched to merchants in Philadelphia, four to New York and one to Baltimore 94 percent of the consignments went to ports in the mid-Atlantic United States. The only other export, or six percent of the total number of consignments, was made up of 8,883 yards destined for the Spanish port of Corunna. The total lineal yardage ${ }^{26}$ of bounty linen was 270,003 yards - 97 percent to one region and three percent to the only other market at this particular time.

A total of 7,918,911 yards of 'not for Bounty' linen, despatched in 57 consignments, left Dublin for English (77.2 percent), Scottish (14 percent), Welsh (3.5 percent) and European (3.6 percent) ports and one consignment of 675 yards was destined for Antigua. ${ }^{27}$ English merchants imported from Dublin a total of 7,596,517 yards in 44 consignments or an average of a little over 172,500 yards per consignment. However, there are wide variations in the quantities per consignment, with a consignment of only 200 yards as the smallest and several very large shipments of 625,000 yards are listed. London received 11 consignments totalling 3,203,910 yards and Liverpool 14 consignments totalling 1,990,647 yards. London imports were twice as large as those to Liverpool.

\footnotetext{
2529 George II c.15 et al.

${ }^{26}$ Linen cloth was woven into varying widths, the most common of which were $7 / 8$ ths of a yard wide or yard-wides. Thus they were of varying weights according to the thickness of the yarn used in the weaving process. The cloth was sold in 'pieces' each of 25 linear yards or 50 yards in a 'double.' Eaton used figures in linear yards but other reports discuss numbers of 'pieces' of linen cloth; W. H. Crawford, The Impact of the Domestic Linen Industry in Ulster, Belfast, 2005. In all instances the yardage figures used in this thesis are linear measurements and no attempt has been made to calculate any other volume or quantity of goods.

27 As the Goodwill departed Dublin 1 February (New Lloyd's List) and this quantity of linen cleared customs outwards on that day, it would be a reasonable assumption that the linen listed on the inwards record at Antigua for John Sinnot's vessel is, in fact, this linen.
} 
English ports dominated imports of Irish linen yarn. The hanks of linen yarn, each of a standard 300 yards in length, varied in weight according to the thickness of the strand of yarn. As with the other commodities measured in weight, it is important to consider both the number of consignments and the volume of goods involved. Of the 41 consignments of linen yarn despatched from Dublin, 27 were destined for English ports; this equates almost 66 percent of the number of consignments. Liverpool received 23 of the consignments, Bristol four and London received none of the consignments. Calculated by weight, English ports received $2,010 \mathrm{cwt}$ of the total of 2,442 cwt of yarn and Scotland approximately $432 \mathrm{cwt}$; this translates to 82 percent for the English ports and 18 percent for the Scotland. Thus, whether market share is calculated from the number of consignments or the volume of goods, England is the dominant market for linen yarn.

The third main category of commodity covers a wide variety of goods and has been classified by this author as "merchants' goods." They have very little in common and can really only be itemised rather than analysed. An example of the miscellany is the barilla ashes that cleared customs on 22 January 1785 destined for London. Barilla ashes are alkaline and as well as being used in soap-making they were used in the linen manufacturing process. Their appearance on this list as an export is unusual; one explanation would be that this was a re-export.

The small quantities of cambricks (cambric cotton), corduroys, cotton and drapery to Philadelphia may have, in fact, cleared customs as personal belongings of passengers leaving for a new life rather than items of export trade. In contrast, the 62cwt 3 quarters and 23lbs (pounds) of feathers sent to London, Liverpool and Lancaster imports would have been commercial trade. The demand for feather beds and pillows in England was high, it would seem, in 1785; a very large number of Irish birds must have lost their feathers to fulfil these orders! Those birds that were not plucked for their feathers were possibly allowed to grow and supplied the 1,023,000 quills exported to English and Scottish ports.

An enormous number of rabbits must have died to produce the $1,2641 \mathrm{bs}$ of 'furr' [sic] exported to Liverpool and Chester. In contrast to these somewhat curious exports, it is entirely possible that the $1,596 \mathrm{cwt}$ of flour sent to Liverpool and 
Whitehaven was used to provision vessels while the 3,721 barrels of oats destined for ports in Scotland formed part of the total 85,745 quarters of oats and oatmeal imported into Scotland from Ireland in $1785 . .^{28}$ Rather than large-scale commercial operations these items are all minor quantities of miscellaneous goods and no specific patterns of trade are obvious.

In this examination of the main categories of goods, and detailed analysis of the key commodities listed by Richard Eaton as exports from Dublin in the first quarter of 1785, English ports received more consignments than any other region or country of destination in eight of the nine commodity sectors examined. They received 55.8 percent of the beef, 70.2 percent of the hides \& skins, 70 percent of the butter exports, over 90 percent of the bacon products, almost all of the barrels of pork, 93 percent of the tallow and 43 percent of the tongues. England was only usurped in one item of the 'hides and skins' key commodity, and in that category all of the tanned hides went to European ports. A little over 77 percent of linen cloth "not for bounty" was despatched to English ports, and 14 percent to Scotland; not linen cloth for bounty went to English ports.

England received the vast majority of consignments with some market specialisation resulting not from within the market but because of subsidy and government regulation, that is, the bounty scheme for consignments of linen cloth offshore to markets other than those of England. According to Eaton's "List", all 27 consignments of linen yarn went to England. Liverpool received 85.2 percent and Bristol 14.8 percent of those consignments.

For the merchants and exporters of Dublin, the English market loomed large. The convenience of shipping goods a relatively short distance, and the large number of consumers in that particular market, it made economic sense to choose to send their goods to the English ports. The markets of Europe - Bordeaux, Oporto, Corunna etc - were destinations for Irish goods only because of the return cargoes and the historical ties between the merchant communities. These were important factors in the decision-making process; the ability of the merchants to procure return

28 Table 31, L. E. Cochran, Scottish Trade with Ireland in the Eighteenth Century, Edinburgh, 1985, p.100. 
cargoes for the consumers of Dublin, who demanded the importation of a great variety of goods, was a top priority. The increasing population required and wanted not only basic necessities but also luxury items. ${ }^{29}$

\section{- II -}

Thus far we have determined where the consignments leaving Dublin were going and what the main categories of goods were that appeared in Eaton's "List" as cleared customs outwards in the first quarter of 1785 . We have identified which main ports in those countries or regions received what percentage of the goods and analysed the market shares of key commodities. Now we will examine Eaton's document for imports into Dublin to determine where the goods came from and what the main categories of imported goods are.

Ireland was not an 'industrialised' country at this time and is often portrayed as lacking natural resources. The land is best suited for agrarian purposes although Whitworth, writing in 1776, pointed out that the "mines of coals, copper, silver, and lead and quarries of marble" had "not long been discovered" but "those of iron were discovered and worked so early as the reign of Queen Elizabeth." $\mathrm{He}$ lamented: "many causes have concurred to prevent Ireland from improving too rapidly, or so effectually as many other parts of the British dominions." 30 While many of the hindrances to Ireland's industrialisation were political and a direct result of the control England exerted over the kingdom at varying times, I would suggest, however, that as a result of that interference Ireland became a specialist exporter of what she did best - primary produce and by-products, and linen yarn and linen products, as we have seen above. With this focus on agrarian use of the land, there was a need, therefore, for the importation of those goods which Ireland neither had the resources to produce, or could not produce at an economic unit price.

\footnotetext{
${ }^{29}$ The population of Dublin is quoted by Louis Cullen as 58,000 in 1682 and 200,000 in 1800; Louis Cullen, Anglo-Irish Trade, 1660-1800, Manchester, 1968. In 1798 it was - according to the entry for Dublin City in the Hutchinson Encyclopaedia - 168,000; URL: http://encyclopedia.farlex.com/Dublin+(city) accessed 3 December 2007.

${ }^{30}$ Whitworth, State of the trade, p.xxxvi.
} 
Eaton's "List" details 2,176 individual consignments of goods arriving in Dublin. There are 244 different types of goods listed. ${ }^{31}$ These goods have been organised by this author into four main categories to facilitate analysis consumables, raw materials, manufactured goods, and personal consumables. The category of 'consumables' includes items of food such as cheese, flour, sugar, potatoes, and beverages such as tea, coffee, cider, beer, brandy, and rum. 'Raw materials' include coal, steel, iron, slates, bricks, fuel oil, wood, and seeds while 'manufactured goods' range from bottles, scissors, scythes, needles, tobacco pipes, to earthenware and lawns, muslins, and toys. Items such as stockings, gloves, hats, handkerchiefs, coaches, and post-chaises are classified as 'personal consumables.'

\section{Illustration 1.4: Eaton's “List" - An example: Imports into the port of Dublin}

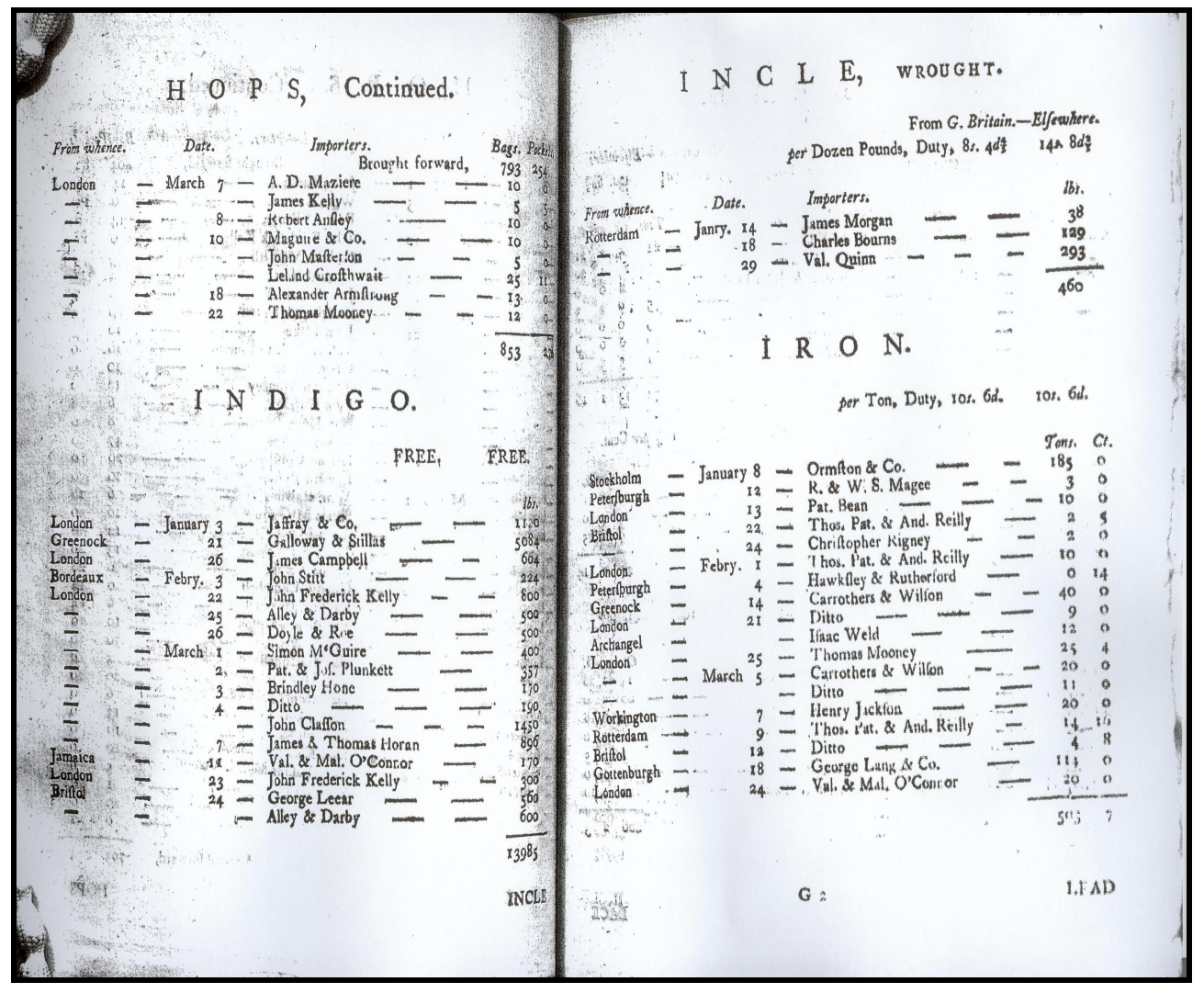

Illustration 1.4: Reproduced with written permission from Dr Máire Kennedy, Divisional Librarian, Special Collections, Dublin City Public Libraries.

\footnotetext{
31 This number would be higher if the missing pages of the document - which begin with 'Turpentine' and ends part way through 'wine' - were still present.
} 
Illustration 1.5: Eaton's “List" - Imports: an explanation

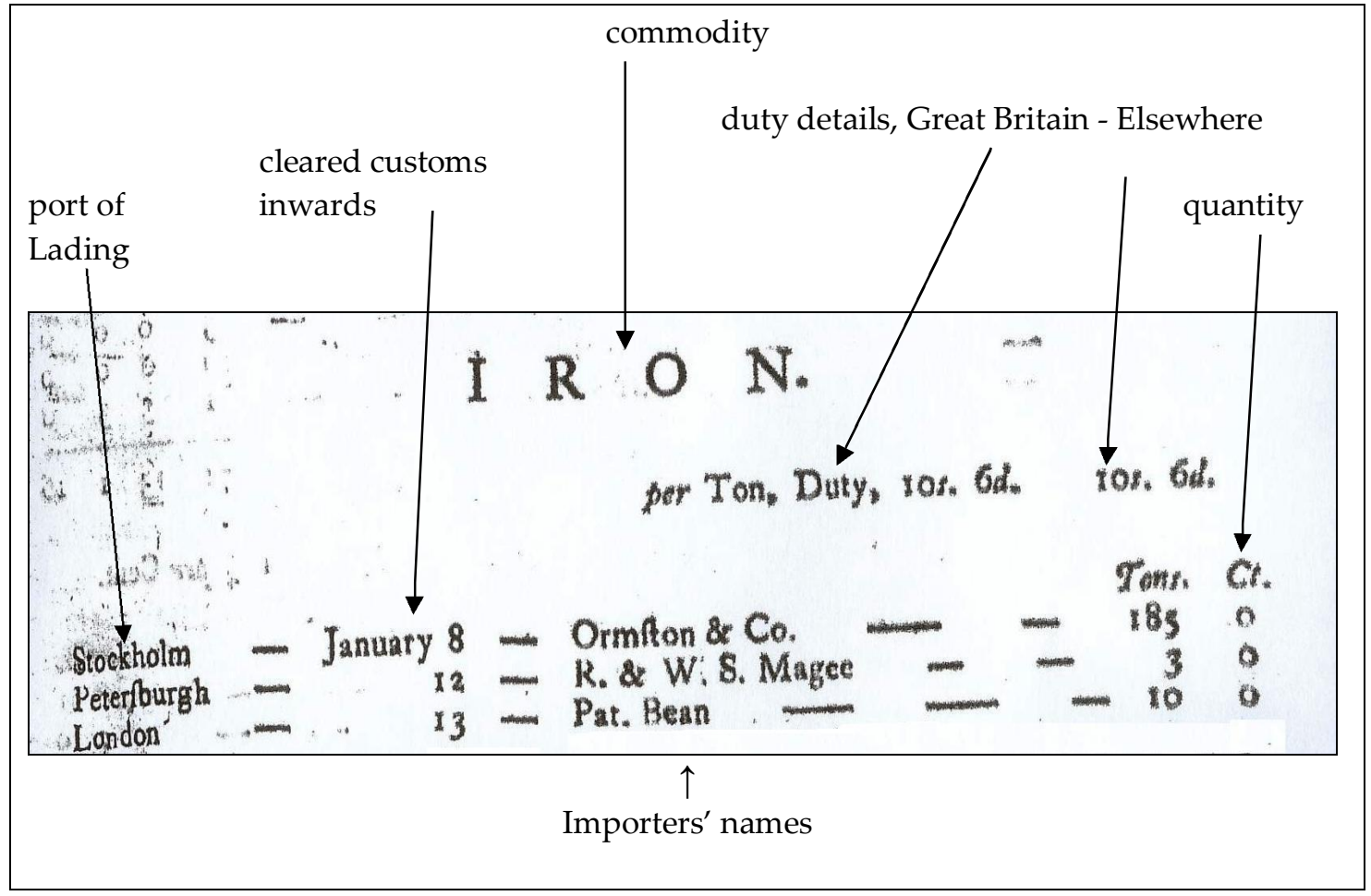

Rather than consider each individual type of good imported, let us consider a few of the key quarterly imports and first spotlight coal; 36,762 tons of coal arrived in Dublin. In the last two days of December 1784 1,742 tons arrived, 11,742 tons arrived January, 12,392 tons in February, and 10,886 tons up to and including 24 March 1785. The list shows that consignments varied from only 94 tons (which would easily fit in the hold of one vessel), up to 1,468 tons in another (which have arrived, no doubt, in more than one vessel).

Eaton does not specify where the coal came from or who imported it but Ireland imported a little over 25,000 tons of coal from Scotland in 1785, the vast majority of which came from coalfields in Ayrshire. ${ }^{32}$ It was used for commercial and domestic heating and the production of steam. Three-fifths (15,000 tons) of that coal went to Dublin ${ }^{33}$ and it would be reasonable to conclude that a large proportion of the coal in Eaton's "List" for the first quarter of the year came from Ayrshire.

A great deal of coal was produced from mines in the north-western counties of England and one possibility is that the coal came from Whitehaven. According to William S. Jevons, "Ireland, especially Dublin, has drawn coal from Whitehaven

${ }^{32}$ Cochran, Scottish Trade, p.28.

${ }_{33}$ Table 7; ibid, p.34. 
time out of mind, for domestic purposes and local manufactures." ${ }^{34}$ Nearly seven and a half million tons per annum were produced in mines stretching from Lancashire to Gloucestershire between 1781 and $1790 . .^{35}$

The coalfields and the coal exporting ports of Wales lay only a short sea journey across the Irish Sea from Dublin; the port of Holyhead is only 60 nautical miles $(111 \mathrm{~km})$ from Dublin and Swansea is 138 nautical miles $(255 \mathrm{~km})$ away. ${ }^{36}$ Of all the possible sources of the coal on Eaton's "List" this is the most likely source of the large quantities that cleared customs on 31 September 1784 (1,213 tons), 3 January 1785 (1,468 tons), 1 February (909 tons), 17 February (1,095 tons), 21 February (1,458 tons), 25 February (1,199 tons), 7 March (1,291 tons), and 22 March (998 tons). Welsh mines produced an average of 800,000 tons per annum between 1781 and 1790 and while the vast majority was sent to the highly industrialised Lancashire industries, a proportion was exported to Ireland. ${ }^{37}$

Seeds of all types were another 'raw material' that arrived in large quantities in Dublin. Poor seed harvests from the annual crops forced merchants to import vast quantities of crop seed. There was obviously a thriving domestic seed market also as 10,8631 bs of "garden seeds" cleared customs ready for the spring planting in April and the following months. In addition, 57cwt of canary seed appeared in Eaton's "List", referring to the seed of canary grass (phalaris canariensis), which is ground into flour. The $604 \mathrm{cwt}$ of clover seed imported was utilised for pasture as, no doubt, was the $244 \mathrm{cwt}$ of trefoil seed imported into Dublin via the London market. The trefoil is extremely fine seed used to improve pasture quality. ${ }^{38}$

The flax seed imported from the former American colonies was favoured over the European imports, with only three consignments from Rotterdam

\footnotetext{
${ }^{34}$ Chapter XIII; William S. Jevons, The Coal Question: An Inquiry concerning the Progress of the Nation, and the Probable Exhaustion of our Coal-mines, London, 1865, (2nd edition, 1866, revised).

35 Table 3; Sidney Pollard, 'A New Estimate of British Coal Production, 1750-1850', Economic History Review, Vol. 33, no. 2, May 1980, p.216.

${ }^{36}$ Liverpool is 117 nautical miles (216kms) from Dublin; Glasgow 162 nautical miles $(300 \mathrm{~km})$; London 253 nautical miles $(469 \mathrm{~km})$. Bordeaux is 562 nautical miles $(1,042 \mathrm{~km})$, Oporto 744 nautical miles $(1,377 \mathrm{~km})$, and Naples 1,122 nautical miles $(2,078 \mathrm{~km})$. URL http://timeanddate.com/worldclock/distances.html, accessed 3 December 2007.

${ }^{37}$ Interestingly, there are very few exports, that is, return cargoes, from Ireland to Wales.

38 Information regarding canary grass: URL: http://chestofbooks.com/flora-plants/weeds/Manual-OfWeeds/Canary-Grass-Phalaris-Canariensis-L.html, accessed 3 December 2007. Trefoil seed data from URL: http://www.plant.uoguelph.ca/performance_recommendations/ofcc/pub/btprod.htm, accessed 3 December 2007.
} 
compared with the ten consignments from Philadelphia and New York. A total of 1,179 hogsheads cleared customs between 13 January and 12 March 1785. This would no doubt have been used in the new spring planting of the linen flax plants. The germination rate of the American seed was superior to that of the European seed. The American seed thus produced a better crop and was preferred over the inferior European seed. ${ }^{39}$

Hemp seed, sourced from overseas but loaded onto vessels out of London, also arrived by the bushel load. This would have been used to produce the hemp used in cordage and rope manufacture. A total of 458 bushels arrived in Dublin and cleared customs. As the weight of the bushel varied according to the type of grain stored in it, it is impossible to know exactly at what weight those 458 bushels tipped the scales.

Another crop seed, the extremely fine onion seed, totalling 2,288kg, arrived in eight consignments from Rotterdam and three consignments from Oporto; 20 consignments were loaded in London, two in Liverpool and two in Chester. Pea and bean seeds, much heavier than onion or hemp and flax seed arrived totalling 1,904 bushels. Only one shipment came from Europe (Rotterdam) and the remainder have London or Bristol as their port of lading. It is entirely possible that all the seed came from Europe and was purchased in the market in London.

Almost one million litres of various types of alcohol arrived in Dublin from England and southwest Europe in the first quarter of 1785 and 'beverages' featured prominently in Eaton's "List." These include the 4,148 hogsheads of beer, 31 puncheons/52 hogsheads of cider, 363 puncheons/76 hogsheads of Brandy, and 38 puncheons/67 hogsheads of Geneva (a type of gin). A total of 548 puncheons/31 hogsheads rum also cleared customs in Dublin. ${ }^{40}$ Although the initial part of the

\footnotetext{
${ }^{39}$ W. H. Crawford, The impact of the Domestic Linen Industry in Ulster, Belfast, 2005; Brenda Collins, and Philip Ollerenshaw (eds.), The European Linen Industry in Historical Perspective, Oxford, 2003.

40 According to the Oxford Dictionary Online "The London hogshead of beer contained 54 gallons, that of ale 48 gallons; elsewhere the hogshead of ale or beer contained 51 gallons." This equates to 238 litres of beer and 218 litres of ale. The capacity of a puncheon varied from 72 gallons (for beer) to 120 (for whisky) which equates to 327 litres for beer and 545 litres for whisky. http://dictionary.oed.com.helicon.vuw.ac.nz/, accessed 12 January 2008.
} 
section of the "List" titled 'Wine' is missing, ${ }^{41}$ nevertheless the total remains for Portuguese wine. Portuguese wines total 479 pipes, 122 Qcasks and 103 hogsheads. ${ }^{42}$ As Eaton has annotated this list in his own handwriting with a ' $Q$ ' in front of the word cask, it is possible that this indicates he means the container was either a firkin or a tertian which lies between a pipe and a hogshead in terms of capacity. This particular type of cask holds 318 litres. The quantity of wine imported from Portugal therefore becomes: 479 pipes (equals 229,920 litres), 122 firkins/tertians (equals 38,796 litres), and 103 hogsheads (approximately 23,175 litres) - a grand total of approximately 291,891 litres from just one region.

Ireland had a thriving brewing industry as well as several distilleries and so it is not surprising to find that the ingredients to brew or distil alcoholic beverages also feature in Eaton's "List." Imports of hops totalled 853 bags (each weighting $2.5 \mathrm{cwt}$ ) and 271 pockets (each weighing $1.5 \mathrm{cwt}$ ), ${ }^{43}$ and a proportion of the sugar entering the port was no doubt used in the brewing process. Malt was definitely a vital ingredient and 6,671 barrels arrived, mostly from Yarmouth. Some, if not all, of the 837 dozen glass bottles and the 282 gross of corks imported would be utilised to store the end product.

If, however, non-alcoholic beverages were wanted, certainly tea was readily available. Green tea, black tea and the inferior "miserable" leaves arrived in huge chests. $128,486 \mathrm{lbs}$ of green tea and $168,3291 \mathrm{bs}$ of black tea leaves cleared customs in Dublin in the first quarter of 1785; Miserable imports totalled 936lbs. Coffee consumption was definitely only for the wealthy at this time; 25 cwt arrived direct from Grenada and cleared customs on 19 February; duty was payable at the rate of $£ 79$ s 3-3/10d per cwt - one of the highest rates of duty payable on any import into the country.

'Drugs' and chemicals were imported into Dublin in relatively small quantities; nevertheless they fill several pages of Eaton's "List." Some were utilised

\footnotetext{
${ }^{41}$ It is possible that we are missing 'Wine - French' as a category. Certainly the missing signature begins with 'Turpentine' as that is the catchword on the bottom of the last page we have before the gap is evident.

42 A 'pipe' is in fact a barrel that holds two hogsheads of wine or approximately 480 litres.

${ }^{43}$ Peter Mathias, The Brewing Industry in England, 1700-1830, Cambridge, 1959, p.494; Each bag weighs $127 \mathrm{~kg}$ thus the total is $108,331 \mathrm{~kg}$ or over 108 tonnes; each pocket weighs $76 \mathrm{~kg}$ thus the total is $20,596 \mathrm{~kg}$ or over 20 tonne. All imports of hops total 128,927kg (128.9 tonne).
} 
during the production of linen cloth, dying processes, tanning, soap-making, or for medicinal purposes. For example, 783cwt of alum entered through customs between 3 January and 24 March 1785. Alum was used in the tanning process following the removal of the hair from the pelt. It could also be used medicinally as an antiseptic.

The 150lbs of the aphrodisiac cantharides was, no doubt, used for its other medicinal use - as a counter-irritant. The drug is highly toxic and death results from its misuse. ${ }^{44}$ The one and only shipment cleared customs in Dublin from Leghorn on 17 January 1785. Two of the three consignments of ipecacuanha, cleared customs from London and the other from Chester, however, the drug is derived from the dried rhizome of a South American shrub and was used as an emetic and expectorant drug. ${ }^{45}$ According to Eaton's "List" a total of $68 \mathrm{lbs}$ arrived in the first three months of the year, transhipped to Dublin through London and Chester.

The artificial category of 'Personal consumables' covers a wide variety of goods, most of which would have been on-sold to the elite of Dublin. Dozens of silk gloves and handkerchiefs arrived along with candlesticks and goblets for their fine houses. Two coaches arrived within a day of each other - one for Mr R. Ward, Esq., and the other for Mr C. O'Callaghan, Esq. Each paid duty of $£ 613 \mathrm{~s} 63 / 4 \mathrm{~d}$. Eaton does not specify where they came from, nor did he specify a port of lading for the 12 post-chaises that cleared customs in Dublin - five in January, two in February, and five in March. Customs collected $£ 49 \mathrm{~s} 1 / 2 \mathrm{~d}$ for each of the items.

Table 1.7: Country or region of lading of imports into Dublin

\begin{tabular}{|l|c|c|}
\hline \multicolumn{1}{|c|}{ 'Country' of Lading } & No. of consignments & \% of total imports \\
\hline England + Wales & $\mathbf{1 , 4 1 1 + \mathbf { 1 2 }}$ & $\mathbf{6 4 . 8 \% + \mathbf { 0 . 6 } \%}$ \\
\hline Europe & $\mathbf{5 1 6}$ & $\mathbf{2 3 . 7 \%}$ \\
\hline Scotland & 80 & $3.7 \%$ \\
\hline American Colonies & 67 & $3.1 \%$ \\
\hline n.s. & 68 & $3.0 \%$ \\
\hline Caribbean & 24 & $1.1 \%$ \\
\hline & $\mathbf{2 , 1 7 6}$ & $\mathbf{1 0 0 . 0} \%$ \\
\hline
\end{tabular}

Source: Eaton's “List”

${ }^{44}$ URL: http://chestofbooks.com/health/materia-medica-drugs/Roberts-Bartholow/Practical-Treatise/ Cantharis-Cantharides.html, accessed 7 December 2007.

${ }^{45}$ ibid. 
The number and type of imports far out number those of the exports and with so many different types of imported items, it is difficult to present a full discussion of each item or category, as we have with regard to exports, about percentages and market shares. Therefore, a limited discussion follows. Table 1.7 shows that 65.4 percent of the imports are from England and Wales, ${ }^{46}$ and 23.7 per cent of the consignments loaded in European ports.

Table 1.8: Ports of lading in England

\begin{tabular}{|l|c|c|c|}
\hline \multicolumn{1}{|c|}{ Port of Lading } & $\begin{array}{c}\text { No. of } \\
\text { consignments }\end{array}$ & $\begin{array}{c}\text { \% of total no. of } \\
\text { consignments from } \\
\text { English ports }\end{array}$ & $\begin{array}{c}\text { \% of total no. of } \\
\text { consignments }\end{array}$ \\
\hline London & $\mathbf{6 6 8}$ & $47.9 \%$ & $\mathbf{3 0 . 7 \%}$ \\
\hline Chester & $\mathbf{3 4 0}$ & $24.4 \%$ & $\mathbf{1 5 . 6 \%}$ \\
\hline Liverpool & $\mathbf{2 3 2}$ & $16.6 \%$ & $\mathbf{1 0 . 7 \%}$ \\
\hline Bristol & 87 & $6.2 \%$ & $4.0 \%$ \\
\hline Yarmouth & 29 & $2.0 \%$ & $1.3 \%$ \\
\hline n.s. & 16 & $1.1 \%$ & $0.8 \%$ \\
\hline Chepstow & 9 & $<1 \%$ & $0.4 \%$ \\
\hline Lancaster & 6 & $<1 \%$ & $0.3 \%$ \\
\hline Chichester & 5 & $<1 \%$ & $0.2 \%$ \\
\hline Whitehaven & 5 & $<1 \%$ & $0.2 \%$ \\
\hline Weymouth & 4 & $<1 \%$ & $0.2 \%$ \\
\hline Barnstaple & 2 & $<1 \%$ & $0.1 \%$ \\
\hline Gloucester & 2 & $<1 \%$ & $0.1 \%$ \\
\hline Isle of Man & 2 & $<1 \%$ & $0.1 \%$ \\
\hline Workington & 2 & $<1 \%$ & $0.1 \%$ \\
\hline Barmouth & 1 & $<1 \%$ & $<0.1 \%$ \\
\hline Southampton & 1 & $<1 \%$ & $<0.1 \%$ \\
\hline & $\mathbf{1 , 3 9 5}$ & & $\mathbf{6 4 . 8 \%}$ \\
\hline
\end{tabular}

Source: Eaton's “List”

Three times as many consignments arrived in Dublin from England than Europe. However, as I cautioned earlier, some of those goods for which Eaton has listed a British port as the port of lading have obviously been sourced elsewhere in the world and on-sold for Irish consumption through the huge London markets. Nevertheless, the large number of consignments cleared customs inwards in Dublin

${ }^{46}$ Caution must be exercised, however, as some of the products listed as arriving from an English port, may have originated elsewhere. 
in the first three months of 1785 is an indication of the dependency of Ireland on Britain to supply it with a large percentage of its raw materials and consumables. Not only were these goods necessary to enable Ireland to produce the commodities for the local and export markets (refer to the chemicals imported for use in the tanning process) but were also fundamental to its pastoral sector (consider the huge quantities of seeds imported).

The ranking of London as the primary port of lading (see Table 1.8) is no surprise. When we considered why it was only the second ranked destination of goods from Ireland I offered the explanation that it was market forces and traditional commercial ties that lured merchants to export to the distant London market. London was of course the centre of commerce in England and the main port for the unloading goods from all around the world. The affluent Dubliners ${ }^{47}$ were just as keen as Londoners to enjoy exotica and merchants were only too happy to oblige.

It is surprising, however, that Chester is the second ranked port of lading. Chester was a long-established market town with a regular coach service to London but the mouth of the river Dee tended to silt up and the port declined in the mideighteenth century. ${ }^{48}$ Goods had to be transferred to smaller vessels and this was an added cost. Further investigations may show that while the number of consignments outstrips Liverpool, the quantity and type of goods that make up those Chester consignments is of lesser importance than those from Liverpool.

In Europe, the ports of Bordeaux and Rotterdam lead the rankings of ports of lading in Europe for goods bound for Dublin. They each have approximately the same proportion of market share, that is, a little over and under the 30 percent mark respectively. Although Rotterdam is closer to Dublin than Bordeaux, it is more difficult to sail to Rotterdam. Sailing from Dublin down the west coast of England

\footnotetext{
${ }^{47}$ With so many of the merchants being religious non-conformists and dissidents excluded from owning land by law (land is one indicator of wealth), it is difficult to measure the wealth of Dublin's elite. One example, however, is Edward Byrne, who is said to have contributed $£ 80,000$ to the revenue in 1792. Maureen Wall (fn 59, p.108) cites Gilbert, History of Dublin, Volume 1, p.354 who states that Byrne left an estate of $£ 400,000$ when he died. Maureen Wall, 'The Rise of a Catholic Middle Class in Eighteenth-Century Ireland,' Irish Historical Studies, Vol. 11, no. 42, September 1958, p.108.

${ }^{48}$ Henry Rees, 'Evolution of Mersey Estuarine Settlements,' Economic Geography, Vol. 21, no. 2, April 1945, pp.97-103; URL: http://www.Mersey-

Gateway.Org/Server.Php?Show=Connarrative.37\&Chapterid=193, Accessed 7 December 2007.
} 
and around Land's End before entering the English Channel against the flow of marine traffic outwards, the distance is only 402 nautical miles or $745 \mathrm{~km}$. In comparison it is a straightforward 562 nautical mile $(1,042 \mathrm{~km})$ journey to

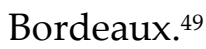

Table 1.9: Dublin imports: ports of lading in Europe

\begin{tabular}{|l|c|c|c|}
\hline $\begin{array}{c}\text { Port of Lading for } \\
\text { goods imported into } \\
\text { Dublin from Europe }\end{array}$ & $\begin{array}{c}\text { No. of } \\
\text { consignments }\end{array}$ & $\begin{array}{c}\text { \% of total no. of } \\
\text { consignments from } \\
\text { European ports }\end{array}$ & $\begin{array}{c}\text { \% of total no. of } \\
\text { consignments }\end{array}$ \\
\hline Bordeaux & $\mathbf{1 6 4}$ & $31.8 \%$ & $\mathbf{7 . 5 \%}$ \\
\hline Rotterdam & $\mathbf{1 5 0}$ & $29.0 \%$ & $\mathbf{6 . 9 \%}$ \\
\hline Oporto & 83 & $16.0 \%$ & $3.8 \%$ \\
\hline Leghorn & 59 & $11.4 \%$ & $2.7 \%$ \\
\hline Malaga & 17 & $3.3 \%$ & $0.8 \%$ \\
\hline n.s. & 11 & $2.1 \%$ & $0.5 \%$ \\
\hline Rouen & 7 & $1.4 \%$ & $0.3 \%$ \\
\hline Cadiz & 5 & $1.0 \%$ & $0.2 \%$ \\
\hline Petersburgh & 4 & $<1 \%$ & $0.2 \%$ \\
\hline Rochfort & 4 & $<1 \%$ & $0.2 \%$ \\
\hline Seville & 3 & $<1 \%$ & $0.1 \%$ \\
\hline Stockholm & 3 & $<1 \%$ & $0.1 \%$ \\
\hline Bilboa & 2 & $<1 \%$ & $0.1 \%$ \\
\hline Gottenburgh & 2 & $<1 \%$ & $0.1 \%$ \\
\hline Archangel & 1 & $<1 \%$ & $<1 \%$ \\
\hline Havre & 1 & $<1 \%$ & $<1 \%$ \\
\hline & 516 & & $\mathbf{2 3 . 7 \%}$ \\
\hline
\end{tabular}

Source: Eaton's “List”

Rotterdam and Bordeaux each held its own attraction for the merchants. Rotterdam in the Netherlands was the clearing port for goods from the north-western provinces of Europe. Eaton's "List" details a wide variety of goods as consigned from Rotterdam with no obvious specialisation in a key commodity or type of goods. Bordeaux channels goods from mainland France and is one of the transit ports for goods from French colonies in North America, Africa and the Caribbean. Bordeaux was the leading port of destination according to the analysis of exports and this is logical as the attraction of the return cargo of brandy drew merchants

${ }^{49}$ URL: http://www.timeanddate.com/worldclock/distances.html, accessed 3 December 2007. 
away from the other ports. All but six of the consignments of brandy that cleared customs into Dublin have Bordeaux listed as their port of lading.

England was the main source of the goods that cleared customs inwards at the Dublin custom house and it was the main market for goods clearing outwards. While Scotland was the second ranked market for exports according to Eaton's "List", it is only the third ranked source of imports. Scotland received one third of the number of consignments leaving Dublin while it only supplied one-twentieth of Ireland's imports.

Ireland was an expanding market for the tobacco merchants of Glasgow and the port of Greenock lay nearby. Dublin's upper classes quickly developed a liking for the goods available to them because of increased foreign and domestic trade and Greenock was a major port of lading for both sugar and tobacco and return cargoes from Dublin were easy to obtain. Ten years earlier, in 1775, Ireland was the third largest market for the tobacco imported from the Chesapeake by the Glasgow merchants and re-exported to France (the largest market), Holland, and Germany. ${ }^{50}$ Between 1785 and 1789 an average 1,004,776lbs of tobacco worth $£ 20,932$ was reexported from Scotland to Ireland. Of the total imports of 4,051,229lbs of tobacco into Ireland in the same period, 25 percent came from Scotland; the vast majority of this entered Ireland through the port of Dublin. ${ }^{51}$

In the case of sugar, 86 separate consignments of raw sugar were imported into Dublin in the first quarter of 1785 equalling "26,566ct/2qr/10lb" and refined sugar loaves totalled "1,328ct/3qr/17lb." Eaton's “List" of imports indicates six consignments, with a total weight of $2,376 \mathrm{cwt}$, left Greenock for Dublin; three shipments totalling 1,631cwt came from Port Glasgow, while 546cwt arrived in Dublin directly from a Caribbean port of lading. ${ }^{52}$

\footnotetext{
50 3,287 hogsheads of tobacco were exported to France, 2,398 to Holland, 1,234 to Ireland and 1,019 to Germany; Tom Devine, The Tobacco Lords: A study of the tobacco merchants of Glasgow and their trading activities c.1740-1790, Edinburgh, 1990, p.65.

51 Table 24; Cochran, Scottish Trade, pp.76, 78.

52 Eaton's "List," imports: 26,566cwt = approx. 1,300 tonnes of raw sugar and 1,328cwt = approx. 67 tonnes of refined sugar. 2,376 cwt $=$ approx. 120 tonnes and 1,631cwt $=$ approx. 83 tonnes.
} 
Between 1785 and 1789, an average of 25 percent of the imports of muscovado sugar into Ireland came from Scotland - often shipped with the tobacco as they originated in the same region. These shipments were, of course, reexports of sugar handled by Scottish merchants; Ireland sourced sugar from England, Scotland and directly from the West Indies as Eaton's "List" indicates. For 1785 only, 65 percent came from England, 18 percent from Scotland, and 17 percent direct. The average value of those imports from Scotland between 1785 and 1789 was $£ 72,552 . .^{53}$

An analysis of Eaton's "List" of Imports and Exports, reminds us England played the major role in Ireland's mercantile and maritime trade. Not only was England the leading supplier of goods - of indigenous manufacture as well as goods imported from overseas and on-sold through the London and Liverpool market places — but it also received by far the greatest proportion of Ireland's exports of primary produce and by-products, linen cloth and yarn, and a handful of miscellaneous goods this author labelled as "merchants' goods." In some cases these goods were transhipped to other markets, but in the greatest number of instances they were for local consumption. With regards to exports clearing customs outwards from Dublin, Scotland was the second largest importer of Irish goods but was not the second ranked supplier of goods for the Irish market; that ranking was occupied by Europe.

53 Table 25; Cochran, Scottish Trade, pp.81, 84. 


\section{Chapter Two: Patterns of Trade and Market Structures}

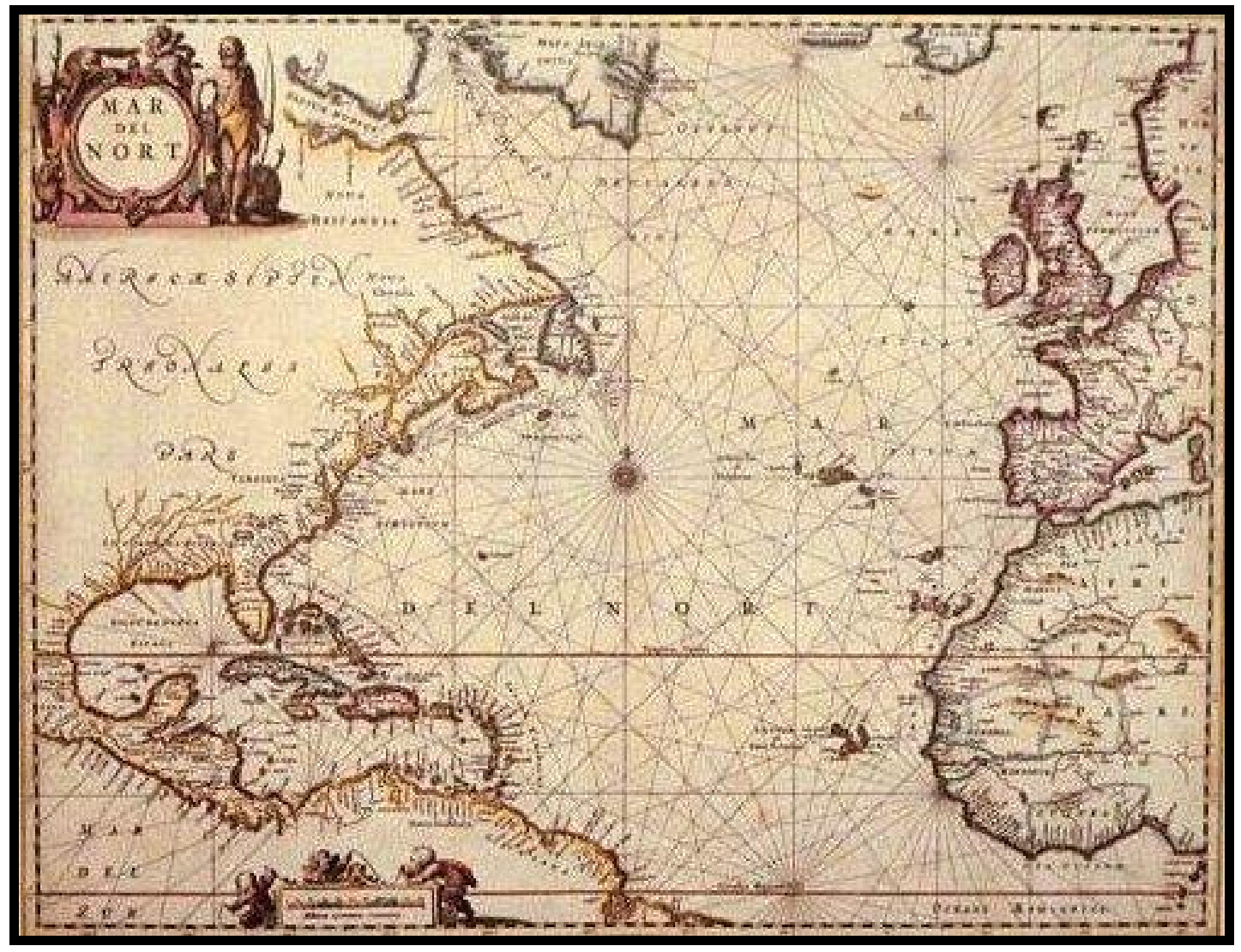


Illustration 2.1: The Dublin Custom House near Essex Bridge, 1782.

Artist: John James Barralet; image reproduced with permission from the Chief Librarian, Trinity College, Dublin.

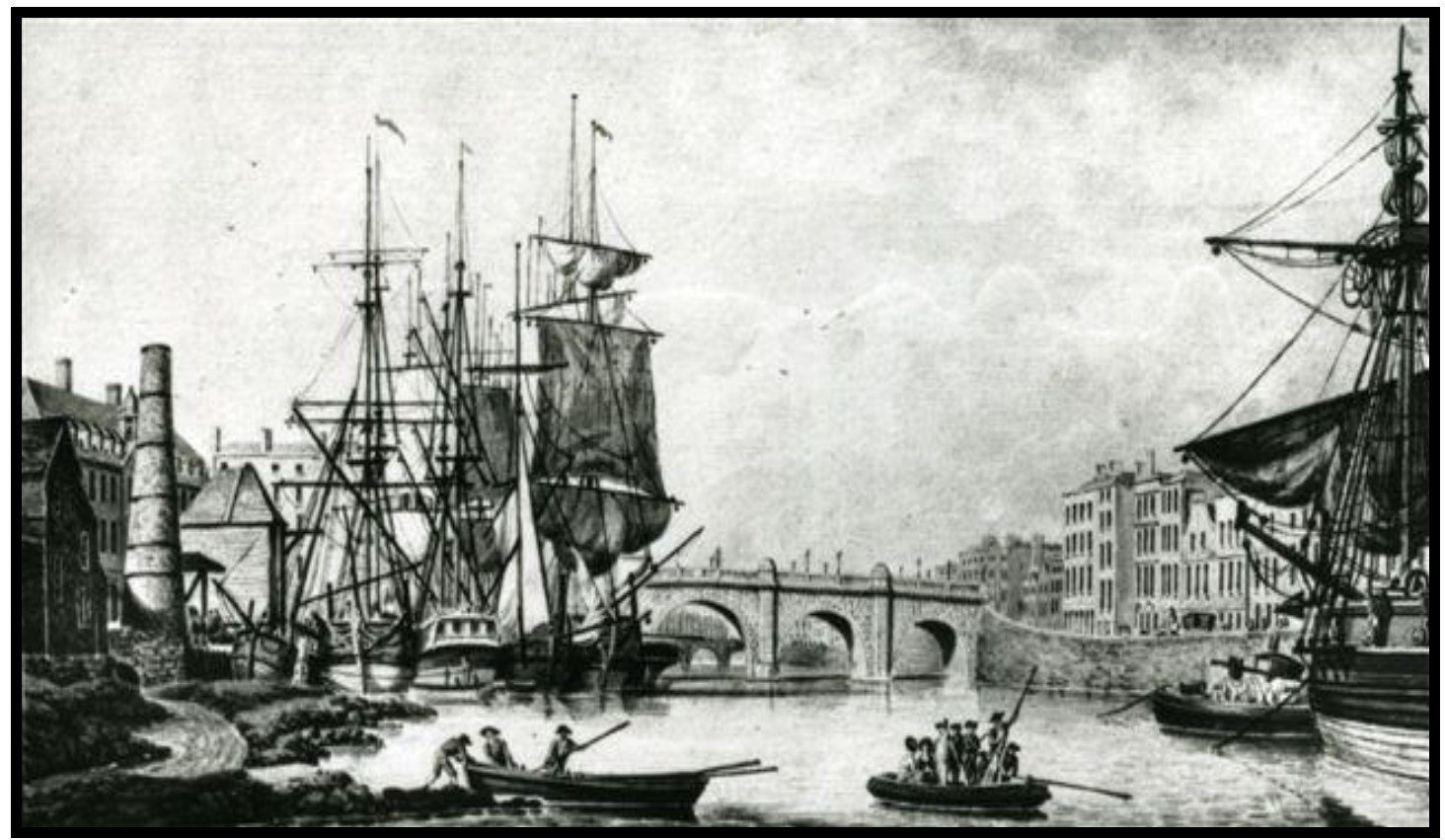

Richard Eaton's A Daily and Alphabetical Arrangement of all Imports and Exports at the Port of Dublin, in the Quarter ending the 25 $5^{\text {th }}$ March, 1785 stands alone in the historiography of Dublin's maritime and mercantile interaction with the rest of world. We cannot check the information against the original customs house records or the Dublin harbour master's log but the contemporaneous newspapers are valuable sources of data. They do not, in the case of Freeman's Journal of Dublin and the Belfast News-Letter, offer the quality of information contained in Eaton's "List" but they do contain enough facts to collate into a database and analyse to determine patterns of trade and market structures.

Eaton's "List" only contains information for the first quarter of the 1785 year. We will now consider other sources of information to, in the first instance, corroborate the information contained in Eaton's document and then to expand the database to cover the full year. I used information contained in the shipping news reports of Freeman's Journal and the New Lloyd's List of vessel movements. This ensured the database contained as complete a picture as possible of all the goods clearing outwards through the port, where they were despatched to; the same sources were used for inwards goods. When goods came from Liverpool or were 
destined for that port, this author used the shipping news reports of the Manchester Mercury and for any matters related to the Caribbean, where the appropriate Naval Office List information still exists, these will be cited.

In this chapter we will examine the shipping reports of the newspapers, New Lloyd's List, Lloyd's Register and the 'Naval Office Shipping Lists' and the database created by this author from the integrated data. The first section of this chapter considers the vessel movements in and out of Dublin for all of 1785, what category of goods or key commodities they state were on each vessel, and where those vessels went to or came from. In the second section, this information is compared with the corresponding data for Dublin in 1770 and in the final part of Chapter Two, the findings are compared with those for another Irish port, Belfast.

\section{- I -}

\section{Illustration 2.2: Port news, port of Dublin from Freeman's Journal}

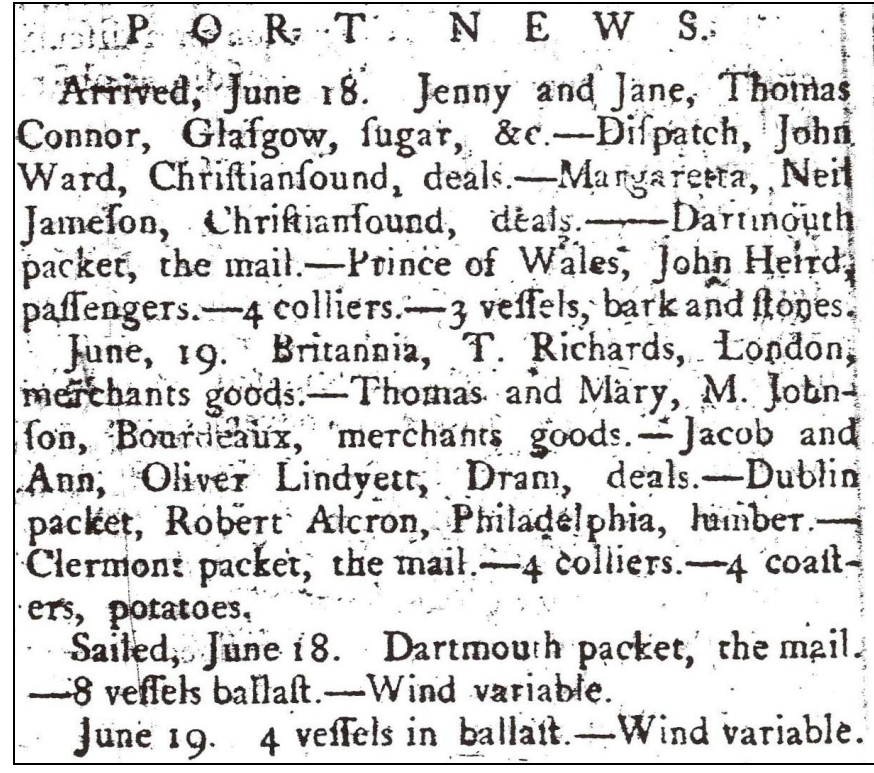

Source: Freeman's Journal, 21 June 1785.

The information for the database of vessel movements in and out of the port of Dublin in 1785 was gathered from the Freeman's Journal of Dublin (hereinafter Freeman's Journal) which reported shipping matters weekly; the port news of the newspaper listed the name of the vessel, the captain, the destination, and the type of goods exported and it was possible to create a good series of data. This was 
corroborated and supplemented with information from the chronological listings of vessel movements in and out of the ports printed twice-weekly in New Lloyd's List.

From the beginning of January 1785 until the end of December 1785 there were 658 vessel movements out of the port of Dublin listed in the Freeman's Journal. For 172 of those vessel movements we have enough information to analyse patterns of trade. ${ }^{55}$ When the 172 comprehensive entries for vessel movements out of the port of Dublin were analysed the following patterns emerged: a little over three-quarters (76.2 percent) of the vessels were destined for England and 11.6 percent departed for European ports. Equal numbers went to Scotland and 'America' but less than three percent went to other ports in Ireland or to the Caribbean (See Table 2.1).

Table 2.1: Vessel movements out of Dublin, 1785

\begin{tabular}{|l|c|c|}
\hline \multicolumn{1}{|c|}{ Country/region of Destination } & No. of vessel movements & \% of total \\
\hline England + Wales & $\mathbf{1 3 0 + \mathbf { 1 }}$ & $\mathbf{7 6 . 2} \%$ \\
\hline Europe & $\mathbf{2 0}$ & $\mathbf{1 1 . 6 \%}$ \\
\hline America & 6 & $3.5 \%$ \\
\hline Scotland & 6 & $3.5 \%$ \\
\hline Ireland & 4 & $2.3 \%$ \\
\hline Caribbean & 3 & $1.7 \%$ \\
\hline Other & 2 & $1.2 \%$ \\
\hline & $\mathbf{1 7 2}$ & $100.0 \%$ \\
\hline
\end{tabular}

Source: Freeman's Journal

Following the addition of the information from New Lloyd's List to the results from the Freeman's Journal, the viable sample size increased to 236. By including information from a second or third source, the integrity of the data is improved substantially. Table 2.2 shows how the percentages of the total number of vessel

\footnotetext{
55 The sample size would be larger but in the case of coastal vessels the reports merely stated that, for example, 'six vessels' departed; there were 49 entries with such aggregate totals for 398 vessel movements; in the majority of these entries the vessels were carrying ballast and either returning to their home port or going to pick up a return cargo. Unfortunately we will never really know where these vessels were going, what they were carrying as ballast, or what the names of the vessels were; therefore, where this information is absent these vessel movements could not be included in the analysis. A total of 29 vessels are not named but have other useful information. Of the 87 entries with no stated destination, 86 were carrying mail or passengers; with names such as Dartmouth Packet, they clearly sailed to ports in the British Isles on a regular basis. The one remaining vessel was carrying tobacco and could have been destined for one of several ports of discharge.
} 
movements out of Dublin for the key destinations changed after the inclusion of the information from New Lloyd's List.

In Chapter One, Table 1.6 listed the number of consignments of each of seven key commodities in the category of 'Primary Produce \& By-products,' based on Eaton's "List" of exports from Dublin, along with consignment numbers and percentages for the two commodities in the Linen yarn \& Linen products' category. Of the 462 consignments, 57.4 percent were linen yarn and 27.5 percent linen products. The number of vessel movements out of Dublin where each of those same commodities makes up the bulk of the stated laden goods was collated from the Freeman's Journal reports only, as the 61 entries from New Lloyd's List contain no information about the goods carried. Of the 171 vessel movements where the commodity was listed, there were six with beef as the main cargo, ${ }^{56}$ three with butter, two with pork, one with tallow, eight with linen yarn, two with tobacco, 57 with mail, 36 with merchants' goods, and 26 with passengers. This data added little to the discussion of patterns of trade for the commodities. The value of the data in the Freeman's Journal and New Lloyd's List lies, therefore, in the information about the destinations of the vessels.

Table 2.2: Revised results - Vessel movements out of Dublin, 1785.

\begin{tabular}{|l|c|c|c|}
\hline $\begin{array}{c}\text { Country/region of } \\
\text { Destination }\end{array}$ & $\begin{array}{c}\text { No. of vessel } \\
\text { movements }\end{array}$ & \% of total & $\begin{array}{c}\text { Analysis of } \\
\text { Eaton's “List” }\end{array}$ \\
\hline England + Wales & $\mathbf{1 4 9 + 1}$ & $\mathbf{6 3 . 5 \%}$ & $65 \%$ \\
\hline Europe & $\mathbf{5 4}$ & $\mathbf{2 3 . 1 \%}$ & $7.6 \%$ \\
\hline America & 15 & $6.6 \%$ & \\
\hline Scotland & 10 & $4.1 \%$ & $20 \%$ \\
\hline Ireland & 4 & $1.5 \%$ & \\
\hline Caribbean & 3 & $1.2 \%$ & \\
\hline \multicolumn{2}{r|}{} & $100.00 \%$ & \\
\hline
\end{tabular}

Source: Freeman's Journal and New Lloyd's List

When Eaton's data was analysed it showed that almost 65 percent of the consignments were destined for England and nearly 20 percent for Scotland, with

\footnotetext{
${ }^{56}$ Where multiple commodities were listed, this author reasoned that as the entries were not in alphabetical order, the order reflected the importance/ranking of the cargo item placed on the consignment by the vessel's master or owner.
} 
only 7.6 percent despatched to Europe. The analysis of the Freeman's Journal and New Lloyd's Lists tabulated in Table 2.2 shows that regardless of the source of the information, England is the leading recipient of goods from Ireland although the ranking of the other markets changed. Europe supplanted Scotland as the second ranked destination of goods leaving Dublin in 1785.

While Scotland's ranking according to Eaton's data is superior to that of Europe, in the analysis for the full year, Scotland is ranked third. I believe this is because fewer vessel movements were identified in the shipping reports and therefore the number is under-reported and skews the analysis. As coastal shipping was not fully reported, it is entirely possible that constant traders between Dublin and Scotland were so frequent that they were merely listed in the aggregate totals that often appeared as entries. For example, "two coasters" departed Dublin on 12 January for 'unspecified' destinations, as did "three coasters" on 30 October, 1785. On the same day "twenty seven vessels" left the port in ballast for unspecified ports. Any or all of those vessels could have been destined for Scotland.

In order to compare the data with that of 1770, the relevant issues of the Freeman's Journal were viewed and the information collated. According to those shipping reports for 1770, 249 vessel movements out of the port of Dublin occurred; this total number would have been much higher had it not been for the 35 entries that merely stated "several vessels" departed the port.

Of those 249 movements, it was possible to analyse 237. Almost 60 percent of the outward voyages were destined for ports in England and a little over one-fifth of the total number sailed for a port in Europe. The data for 1770 shows that only five vessels left for Scotland but many of the unnamed vessels or coasters may have been destined for Scotland. I believe that the findings for Scotland in this instance are unreliable if the data from only the Freeman's Journal are used. However, when the information from New Lloyd's List was added the viable sample became 373 vessel movements.

Supplementing this information with the data from New Lloyd's List made very little difference to the percentage of total vessel movements or the rankings of 
the top two destinations, but clearly changes occurred in the middle of the table. As with the data for 1785, the lack of information about the destinations of the coastal shipping affects the outcome for Scotland's ranking and percentage share.

Table 2.3: Revised results - Vessel movements out of Dublin, 1770.

\begin{tabular}{|l|c|c|}
\hline \multicolumn{1}{|c|}{ Country/region of Destination } & No. of vessel movements & \% of total \\
\hline England + Wales & $\mathbf{2 2 5 + \mathbf { 1 }}$ & $\mathbf{6 0 . 6} \%$ \\
\hline Europe & $\mathbf{7 5}$ & $\mathbf{2 0 . 1} \%$ \\
\hline American Colonies & 18 & $4.8 \%$ \\
\hline Caribbean & 17 & $4.6 \%$ \\
\hline Scotland & 17 & $4.6 \%$ \\
\hline Ireland & 13 & $3.5 \%$ \\
\hline Other & 7 & $1.9 \%$ \\
\hline Total & 373 & $100.0 \%$ \\
\hline
\end{tabular}

Source: Freeman's Journal and New Lloyd's List

The database of vessel movements for 1770 contained 373 entries for the period January to October, suggesting that the number would have been higher if the issues for November and December were available, ${ }^{57}$ the database for the full year, 1785, contained only 234 vessel movements. Normally one would expect to find with improved technology and efficiencies over time (such as the fifteen years between 1770 and 1785) that the numbers would have increased. Let us consider why that did not occur in this case. It is entirely possible that the volume of goods carried on the lesser number of voyages in 1785 was larger per voyage than those of the greater number of voyages of smaller capacity vessels in 1770 .

While debate continues amongst academics as to the 'real' tonnages of the eighteenth century merchant fleet, nevertheless the series of data on which port duties were based provides evidence of this increase capacity of vessels, regardless of which measurements are used. ${ }^{58}$ In the data series for the port of London the average 'tonnage' of the vessels was 75.2 tons in 1770; by 1785 it was 94.8 tons, and

\footnotetext{
57 The November and December issues of New Lloyd's List are lost and no information remains in any other media to cover these missing months.

${ }^{58}$ Contributors to the debate include John J. McCusker, 'Colonial tonnage measurement: Five Philadelphia merchants Ships as a Sample', Journal of Economic History, Vol. 27, no. 1, March 1967, pp.82-91 and Christopher J. French, 'Eighteenth-Century Shipping Tonnage Measurements', Journal of Economic History, Vol. 33, no. 2, June 1973, pp.434-43.
} 
by 1800 it had reached 104.2 tons. ${ }^{59}$ There is no reason to believe that this trend toward larger capacity vessels using the main ports would not also be the case for Dublin.

Another possible scenario relates to the weather patterns. We know from the marine news contained in New Lloyd's List that 1785 was a particularly bad hurricane season in the Caribbean and coastal states of America with many vessels lost. Insurance coverage for cargoes may have been difficult to find when the losses began to mount. Only 18 voyages to these regions are recorded for 1785 while 35 departed Dublin in 1770.

This does not however explain the decrease in the number of voyages to England and Europe. Here I believe the problem is with the category of cargo stated in the reports of the Freeman's Journal. Not only do we have a large number of unnamed vessels travelling with ballast, we have, for example, 80 voyages where mail and passengers are listed. Most of the packet vessels advertised that they would carry cargo and many of these vessel movements could be re-labelled if that cargo was listed.

I believe, from my research into this topic, that it is highly likely that the aggregated number of vessels and the unnamed vessels in the reports of the Freeman's Journal were destined for English or Scottish ports. The pattern of trade is such that I believe the majority of those vessels would have, in fact, gone to English ports. I do not believe there would be any marked change in the findings if we did have further details of those vessels and it is quite clear that a substantial proportion of vessels departing Dublin in 1770 and in 1785 sailed for English ports.

In spite of the result of my analysis that shows the number of vessel movements was less in 1785 than in 1770, according to the statistical returns, the value of the goods exported from Ireland to England, increased. For the first seventy years of the eighteenth century, Whitworth's data indicate the recorded value of goods arriving increased by a factor of more than five. His figures for 1700 show $£$ Stg 233,853 worth of goods arrived from Ireland. Between 1700 and 1750 the total

\footnotetext{
${ }^{59}$ Abstracted and computed from Table 1 (p.477) of Abbot P. Usher, 'The Growth of English Shipping, 1572-1922', Quarterly Journal of Economics, Vol. 42, no. 3, May 1928, pp.465-78; originally the Commons Journals, xlvii 353 (no. 17).
} 
value of the goods fluctuated, reaching a peak in 1745 of $£$ tg 1,441,498 before dropping away again to $£$ Stg 612,808 in 1750 but rebounding again and stabilising at over one million pounds by $1770 .{ }^{60}$

In the ensuing years the figures show a continuation of the trend upwards in the value of exports from Ireland to England (see Table 2.4). For the year ending 5 January 1771, according to Whitworth's figures, Ireland exported goods to the value of $£ \operatorname{Stg} 1,214,398$ to England; by 1781 the figure had risen to $£ \operatorname{Stg} 1,549,388$. The 1791 figure was approximately fifty per cent higher again and by 5 January 1800 the exports had reached $£$ Stg 2,445,079. ${ }^{61}$

Table 2.4: Abstract of export values, 1700-1800 ${ }^{62}$

\begin{tabular}{|c|r|}
\hline For the year ended 5 January... & \multicolumn{1}{|c|}{ Ireland Exports to England } \\
\hline 1700 & $£ 233,853$ \\
\hline 1750 & $£ 612,808$ \\
\hline 1770 & $£ 1,214,398$ \\
\hline 1780 & $£ 1,549,388$ \\
\hline 1790 & $£ 2,203,099$ \\
\hline 1800 & $£ 2,445,079$ \\
\hline
\end{tabular}

Source: Whitworth, Cullen, Truxes

\footnotetext{
${ }^{60}$ Whitworth, State of the trade, p.19. 'Great Britain' consisted of the two countries England and Wales until the Act of Union, 1707. After the implementation of the Act, when Scotland's affairs were absorbed into those of Great Britain, the constituent countries of 'Great Britain' then became England, Wales and Scotland.

${ }^{61}$ Cullen, Anglo-Irish Trade, pp.46-7. Cullen used these figures in spite of Schumpeter and Ashton's earlier (1960) criticism of Whitworth's and Inspector-General Culliford's errors, alterations and omissions.

62 Whitworth, State of the trade; Cullen, Anglo-Irish Trade; Thomas M. Truxes, Irish-American Trade, 16601783, Cambridge, 1988. Figures abstracted from Whitworth and Cullen. The summaries are figures stated in terms of value, and not volume, and how Whitworth collated them has been the subject of some debate. John J. McCusker published an article several years after Cullen's book, in which he considered the problems faced by historians keen to use Whitworth's figures. (John J. McCusker, 'The Current Value of English Exports, 1697 to 1800', William and Mary Quarterly, Vol. 28, no. 4, October 1971, pp.607-28). He believes that the 'systematic distortions' of quantities and unit values pose "serious difficulties" but felt that there was some merit in using the Whitworth figures for the creation of a constant value series of trade figures. He explained that the Customs 3 series on which Whitworth focussed did not in fact give the 'real value of trade' because inspectors using "formalized official values derived at the beginning of the eighteenth century" and not current market prices compiled them. Schumpeter also criticised Whitworth for changing the methodology of collating the figures by moving between the official price, the current price, and the market value.
} 
Thus the key indicators for exports - number of consignments, tonnage, value all point to increased activity. The next part of this chapter will consider whether those trends and patterns of trade also occur for the data on imports into Dublin.

- II -

Illustration 2.3: The New Lloyd's List-vessel movements in and out of ports

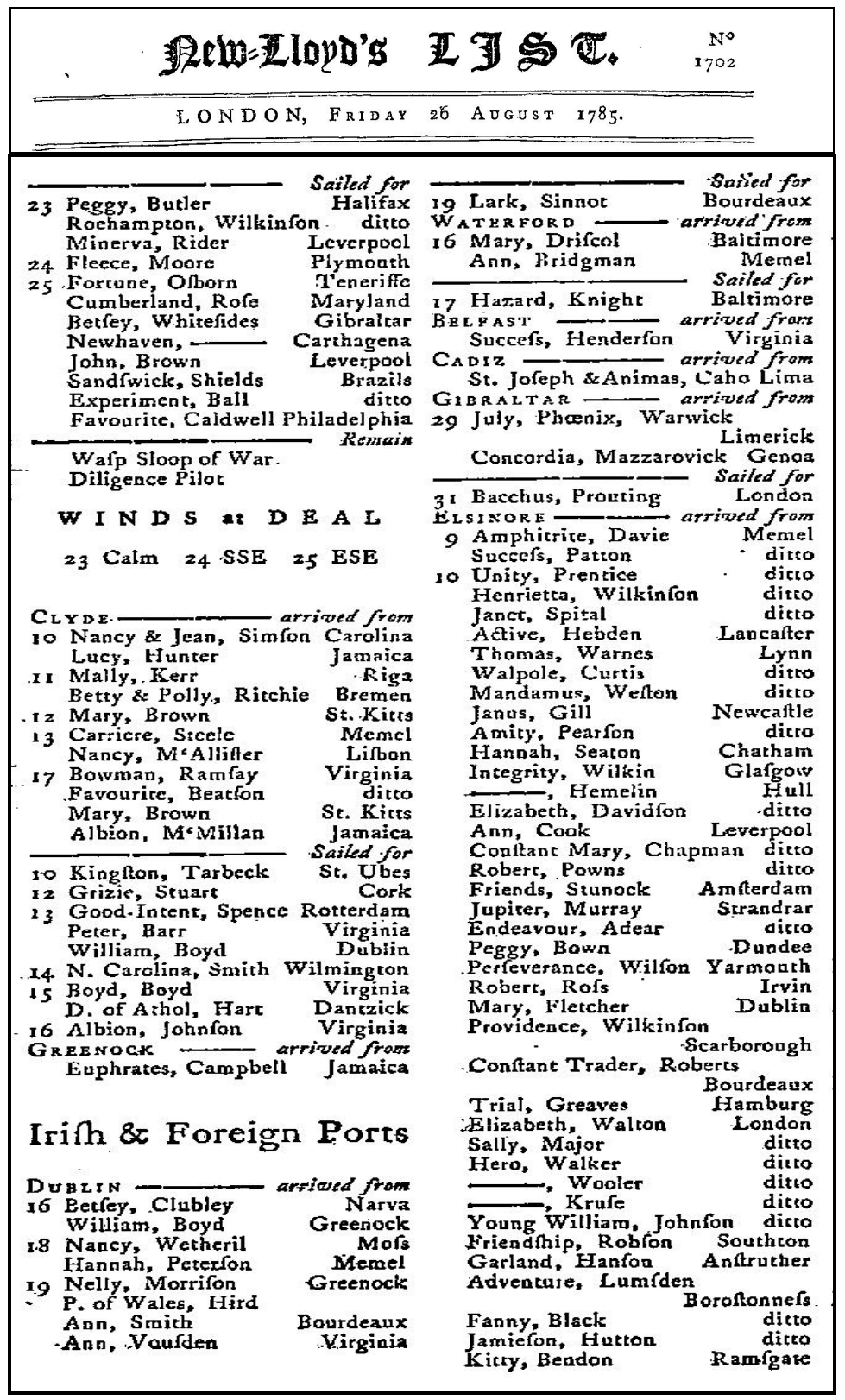

Source: New Lloyd's List, 26 August 1785.

Eaton listed 244 different types of goods imported into Dublin in 2,176 individual consignments. As with exports any number of consignments could have been 
shipped on one voyage and the bill of lading may have contained many different types of goods. The shipping reports of the Freeman's Journal for 1785 contain 416 entries about the vessel movements into the port of Dublin for 1785. Of those entries, 12 vessels are not named but the entries include other information; 141 entries are aggregated totals for a further 712 movements. As with the exports, we will never know exactly where those vessels came from or what they carried but they would undoubtedly have come from England or Scotland. They are listed as colliers, coasters or simply as 'vessels.' The valid data sample for Dublin for 1785 is therefore made up of information for 276 vessel movements.

When the information contained in New Lloyd's List was incorporated, the following occurred:

Table 2.5: Vessel movements into Dublin, 1785

\begin{tabular}{|l|c|c|c|c|}
\hline \multicolumn{1}{|c|}{1785} & \multicolumn{2}{|c|}{ Freeman's Journal only } & \multicolumn{2}{c|}{ Freeman's Journal + New Lloyd's } \\
\hline Country/Region & $\begin{array}{c}\text { Movements } \\
\text { into Dublin }\end{array}$ & $\mathbf{\%}$ of total & $\begin{array}{c}\text { Movements into } \\
\text { Dublin }\end{array}$ & \% of total \\
\hline England + Wales & $\mathbf{1 4 9 + 3}$ & $\mathbf{5 5 . 0 \%}$ & $\mathbf{3 5 1 + 3}$ & $\mathbf{5 6 . 3 \%}$ \\
\hline Europe & $\mathbf{5 0}$ & $\mathbf{1 8 . 2 \%}$ & $\mathbf{1 6 4}$ & $\mathbf{2 6 . 1 \%}$ \\
\hline Scotland & 18 & $6.5 \%$ & 50 & $7.9 \%$ \\
\hline America & 8 & $2.9 \%$ & 34 & $5.4 \%$ \\
\hline Caribbean & 4 & $1.4 \%$ & 10 & $1.6 \%$ \\
\hline Ireland & 3 & $1.1 \%$ & 6 & $1.0 \%$ \\
\hline Unspecified & 41 & $14.9 \%$ & Other - 11 & $1.7 \%$ \\
\hline & $\mathbf{2 7 6}$ & $100.00 \%$ & $\mathbf{6 2 9}$ & $100.00 \%$ \\
\hline
\end{tabular}

Source: Freeman's Journal and New Lloyd's List

With the extra entries from the New Lloyd's List series the data sample increased to 629 and the percentages, that is, the market share, re-aligned accordingly. The ranking of England as the top supplier of goods to the Dublin market, and Europe as the second main source of goods arriving in the port remained valid whether the extra information was there or not.

The analysis of Eaton's "List" for imports into Dublin showed that 65.4 percent of the consignments arriving in Dublin for the first quarter of 1785 came from an English or Welsh port while 23.7 percent arrived from a European port. With the information for a full year of vessel movements into Dublin collated and 
frequencies examined, the breakdown of the much larger data sample for region or country of lading shows that more than half the vessels brought goods from English or Welsh ports and almost the same percentage arrived from a European port.

These figures for the vessel movements in and out of Dublin help convey just how busy the port was. The database constructed by this author records 1,341 vessel movements into Dublin and 658 outwards. This equates to a total of 1,999 voyages or numerically to an average of just over five vessels tying up or pulling up their anchors each day. The shipping reports, however, show that some days were busier than others. For example, on 6 April 1785 "thirty nine coasters" arrived, along with the Clermont Packet, the Dartmouth Packet, the Draper and the Prince of Wales. On the same day "twelve vessels" and "two coasters" departed the port. It is possible, therefore, that there were days when there were no movements in or out of the port.

The question arises, as a result of this evidence, as to whether there is a pattern of trade related to the timing of the shipments of goods. According to the reports in the Freeman's Journal, 94 vessels departed Dublin in 1770 with goods bound for a port in regions other than England and 52 vessels left for European ports; a further 22 vessels bound for European ports were included in New Lloyd's List giving a total of 74 outwards movements to Europe. Six vessels departed in January and 12 in February, six left in March and eight in April, 14 of the vessels left in May and four in June, two in July and four in August, 10 in September, one in October and six in November while only one vessel sailed in December.

The Irish and Baltic seas, as well as the English Channel, could be hazardous during the equinox gales of April and October and in the winter months and hence during December (the worst of the winter months) only one vessel sailed from Dublin for European ports. Even the relatively short distances covered to trade in Europe proved daunting on occasions but regardless of this there is a long, almost continuous trading relationship between the ports of Dublin and Bordeaux, Cadiz, 
Leghorn, Lisbon, Nantes and Oporto on the European mainland and Christiansands and Riga in the Baltic. ${ }^{63}$

The most popular of the destinations for the Europe-bound vessels departing Dublin was Bordeaux; a total of 18 vessels - three in January, three in February, one in April and five in May, one each in June and in August, two in September and one each in October and November - listed this port as their destination. Clearly goods left year-round from Dublin to Europe, and in particular, to Bordeaux. Other European ports included Cadiz, which received ten of the vessels, making it the next popular port in the European rankings for 1770 . One in February, one in March, two in April and one in May, one in August and three in September followed by one in November. The difference is best explained by the role Cadiz's played in the voyages of vessels that departed Dublin for the more distant markets on the American continent or in the Caribbean. These vessels sailed south past Cape Verde (and thus past Cadiz) to pick up the northern Atlantic sea and wind currents and speed them on their journey out across the Atlantic. This is in contrast to the relatively short voyages from Dublin into the Bay of Biscay and on to Bordeaux where a return cargo could be found relatively easily.

In 1785, Bordeaux continued as the most popular European destination for vessels leaving Dublin for European ports; a total of 51 vessels left in the period January to December. The frequency decreased in comparison with the 1770 figures but the pattern of seasonal remained relatively static with the 16 vessels heading for Bordeaux leaving regularly between February and December. Once again the most popular month was May. The seven vessels with Cadiz on their manifests sailed in July, September, October and November. The latter two voyages possibly had final destinations in the Mediterranean with Cadiz merely a stopover port. Voyaging across the Atlantic and into the hurricane season of the Caribbean and southern American ports any time after August was undertaken only by the most experienced of ships' masters in the most seaworthy of vessels. ${ }^{64}$

\footnotetext{
${ }^{63}$ Times of war with France no doubt would affect this statement, but our focal periods are two of the sporadic periods of peace in the latter decades of the eighteenth century in the English Channel and Irish Sea.

${ }^{64}$ Traditional Caribbean folklore has the following advice: “June - too soon; July - stand by!; August look out you must; September - remember; October, all over."
} 
While the data examined for the timing of the voyages show peaks and troughs which could be interpreted as 'seasonality,' there is a logical explanation for the findings; the closer the destination the higher the frequency of voyages and the more stable the weather conditions the better the outcome of the voyage. However, there may be another factor that influenced the timing of the voyages to Europe the type of cargo carried. By far the most common cargo from Dublin in 1785 was "merchant's goods" or "merchandise." As these goods were not perishable they are unlikely to influence the shipping patterns and indeed the data reveals cargoes carried all year round. It is more likely that a pattern will emerge where the cargo could be lost if conditions are not entirely favourable.

According to the shipping reports of the Freeman's Journal, only two of the vessels that sailed from Dublin in 1785 (for ports other than ports in England) carried primary produce such as beef or pork as their cargo. The Hibernia sailed for St Ubes (Setúbal) in Portugal and two unnamed vessels sailed for Bordeaux one with beef and one with pork. Those vessels departed in the relatively cool months of April and May, ensuring to some degree that the goods would not spoil even though most meat at this time was preserved with salt or pickled in brine ${ }^{65}$. Preserving the meat added to the costs of the exports so it was done sparingly on the shorter runs. Until the advent of refrigeration in the nineteenth century, it was of course an absolute necessity for eighteenth century cargoes of meat or fish travelling any distance to be well preserved.

In 1770, beef and butter featured most frequently on the manifests of vessels destined for Europe; 32 vessels carried beef and eight declared butter to be their main cargo upon leaving Dublin. During the hottest months of June through to August no vessels carried butter or beef to Europe. Although there is no mention of butter exports to Europe in the newspaper shipping reports for the first quarter of 1785 (the three shipments are in October and November), Eaton's "List" details

\footnotetext{
65 "To preserve meat butchers did not slaughter animals or salt meat until the onset of cold weather in November." Stephen D. Behrendt cites the example of London slaving merchant, Robert Taylor who stated to Simon Taylor in a letter dated 6 September 1797: "Irish provisions I have before mentioned to you were ordered from Messrs Piercy \& Waggotts, but cannot be got ready till about the month of Nov[embe]r, as they do not begin salting till the cold weather sets in." Stephen D. Behrendt, 'Merchants Decision Making in the British Slave Trade,' William \& Mary Quarterly, Vol. LVIII, January 2001, [fn 34], p.180.
} 
several shipments in the first quarter of the year and again it is significant that these are all cooler months and the destinations were in England or Europe.

Thus the 'seasonality' in the shipping patterns to Europe probably owes more to the type of goods and their production cycles than it does to weather patterns. Shipments to the Caribbean and former colonies of North America are however affected by weather patterns as well as production cycles.

The first two sections of this chapter considered the patterns of trade for Dublin for the full year, 1785, and compared them with the discernable patterns for 1770 . While the frequency changed, the destinations, markets and commodities did not. Let us now place the findings for Dublin in context by comparing it with the patterns for the port of Belfast. To enable this comparison to take place, the shipping reports of the Belfast News-Letter ${ }^{66}$ and New Lloyd's List were amalgamated into one database, and then analysed.

\section{- III -}

\section{Illustration 2.4: Belfast News-Letter banner}

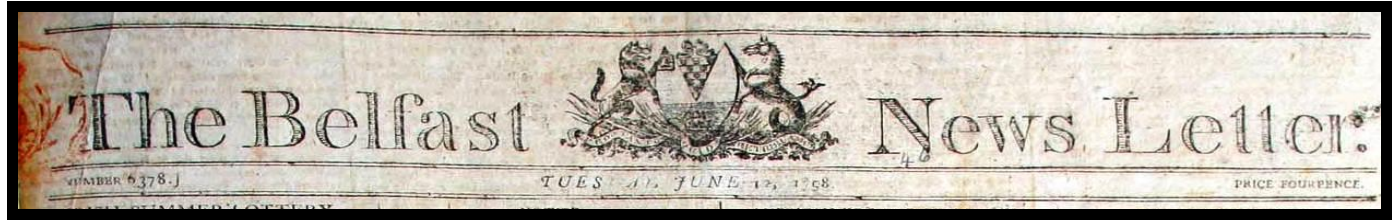

Source: http://www.lynx2ulster.com/BelfastNewsLetter/

Until the early part of the eighteenth century, Belfast was not the main port on the Belfast Lough. Carrickfergus, on the western shores of the Lough, handled all of the exports and imports for Ulster until reclamation of the 'black water' of the River Lagan at Belfast. A number of privately-owned wharves were subsequently constructed on the reclaimed land, and Belfast assumed a greater role in the trading activities of the country as a whole. However, the port was still disadvantaged by the natural restrictions of shallow water, bends in the channel approach and

${ }^{66}$ The Belfast News-Letter was published twice weekly which means a possible 104 issues for the year 1785. 100 of these issues remain available as microfilm copies. Only 21 of these issues contained printed lists of shipping movements and there is a major gap in the period from July to September. 
inadequate quays. In 1785 the Irish Parliament passed an act to deal with the problems of the port that resulted in the formation of the 'Corporation for Preserving and Improving the Port and Harbour of Belfast', commonly called 'the Ballast Board'.

Table 2.6: Vessel movements outwards, Belfast, 1770 and 1785

\begin{tabular}{|l|c|c|l|c|c|}
\hline $\begin{array}{c}\text { Country/region } \\
\text { of Destination }\end{array}$ & $\begin{array}{c}\mathbf{1 7 7 0} \\
\text { Frequency }\end{array}$ & Percent & $\begin{array}{c}\text { Country/region } \\
\text { of Destination }\end{array}$ & $\begin{array}{c}\mathbf{1 7 8 5} \\
\text { Frequency }\end{array}$ & Percent \\
\hline England & 40 & $38.1 \%$ & England & 23 & $32.4 \%$ \\
\hline Scotland & 33 & $31.4 \%$ & Scotland & 21 & $29.6 \%$ \\
\hline Caribbean & 18 & $17.1 \%$ & Europe & 9 & $12.7 \%$ \\
\hline American Colonies & 7 & $6.7 \%$ & Other & 7 & $9.9 \%$ \\
\hline Europe & 4 & $3.8 \%$ & Caribbean & 5 & $7.0 \%$ \\
\hline unspecified & 2 & $1.9 \%$ & America & 4 & $5.6 \%$ \\
\hline Canada & 1 & $1.0 \%$ & unspecified & 2 & $2.8 \%$ \\
\hline Total & $\mathbf{1 0 5}$ & $100.0 \%$ & Total & $\mathbf{7 1}$ & $100.0 \%$ \\
\hline
\end{tabular}

Source: Belfast News-Letter

As with the trend displayed in the Dublin figures, the overall number of vessels departing the port of Belfast in 1785 is lower than that for 1770 (See Table 2.6). We know from the advertisements for the various vessels involved in the export trade from Ireland, and from the records of the Lloyd's Register in-port surveys, that the average burthen weight of the vessels definitely increased during this period. This would explain how the volume of trade increased, as reported in the Annual Returns to Parliament, although the number of voyages decreased. It is also important to note that, as with the Freeman's Journal of Dublin, the Belfast News-Letter reports often only advised that "two colliers" or "three vessels" or "one coaster" had departed. For the purposes of this overview, it is noted that 225 colliers departed Belfast for "home" and with "ballast" listed as their cargo in 1770. In 1785, 44 colliers, two vessels and ten coasters also departed Belfast, again with "ballast" and sailing for "home" or an unspecified destination. ${ }^{67}$

In order to compare the full data for Dublin in 1785 with the equivalent for Belfast, the vessel movements in and out of the port of Belfast shown in New Lloyd's

${ }^{67}$ Unfortunately the Dublin reports have entries for this type of voyage only as "several vessels" and thus the total of this type of vessel movement remains unknown for Dublin. 
List must be added to the shipping reports data of the Belfast News-Letter. As shown in Table 2.7 three times as many vessels departed Dublin in 1785 compared to the vessel movements outwards from Belfast in 1785. This is not a surprising result considering the size differential in the port facilities and the populations they served.

Without a corroborating document for Belfast equivalent to Eaton's "List" we remain ignorant of the exact quantities and type of goods leaving the port although the shipping report summaries of the Belfast News-Letter are a little more comprehensive than those of the Freeman's Journal.

Table 2.7: Vessel movements outwards from Belfast in 1785, compared with vessel movements outwards from Dublin, 1785.

\begin{tabular}{|c|c|c|c|c|c|}
\hline \multicolumn{3}{|c|}{ 1785: Belfast News-Letter + New Lloyd's List } & \multicolumn{3}{|c|}{ 1785: Freeman's Journal + New Lloyd's List } \\
\hline Country/Region & $\begin{array}{l}\text { Movements } \\
\text { out of Belfast }\end{array}$ & $\begin{array}{l}\% \text { of } \\
\text { total }\end{array}$ & Country/Region & $\begin{array}{l}\text { Movements } \\
\text { out of Dublin }\end{array}$ & $\begin{array}{l}\% \text { of } \\
\text { total }\end{array}$ \\
\hline England + Wales & $35+2$ & $43.3 \%$ & England + Wales & $149+1$ & $63.5 \%$ \\
\hline Scotland & 30 & $35.1 \%$ & Europe & 54 & $23.1 \%$ \\
\hline Europe & 24 & $28.1 \%$ & America & 15 & $6.6 \%$ \\
\hline America & 10 & $11.7 \%$ & Scotland & 10 & $4.1 \%$ \\
\hline Caribbean & 7 & $8.2 \%$ & Ireland & 4 & $1.5 \%$ \\
\hline Ireland & 5 & $<1 \%$ & Caribbean & 3 & $1.2 \%$ \\
\hline Fisheries & 2 & $<1 \%$ & & & \\
\hline Unspecified & 2 & $<1 \%$ & & & \\
\hline Total & 117 & $100.0 \%$ & Total & 234 & $100.0 \%$ \\
\hline
\end{tabular}

Source: Belfast News-Letter and New Lloyd's List, 1785; Freeman's Journal and New Lloyd's List, 1785.

The size of the consumer market of Belfast paled in comparison to that of Dublin. Belfast, with a population of only between 12,000 and 15,000 people, according to Arthur Young, and lacking a sizeable upper class, the exotica of Eaton's "List" of imports is absent in the reports relating to Belfast. Instead the exports are clearly the results of the agrarian nature of the surrounding districts and the imports are the means by which the textile industry, specifically the linen industry, thrived in this region. Young listed the exports of Belfast as: “beef, butter, pork, to the West-Indies, and France. The great article linen cloth to London; formerly some to America [the American "War of Independence" curtailed this trade for some years]" and the list 
of imports as: "rum, brandy, geneva, and wines...Coals from Britain. Iron, timber, hemp, and ashes, from the Baltic. Barilla from Spain for the bleach greens. Tea, raw sugars, hops, and porter the principal articles from Great Britain. From North America, wheat, staves, flour, and flaxseed" 68

Table 2.8: Commodities despatched from Belfast, 1770 and 1785

\begin{tabular}{|l|c|l|l|c|l|}
\hline Country/Region & $\# \mathbf{1 7 7 0}$ & \multicolumn{1}{|c|}{ Cargo } & Country/Region & $\# \mathbf{1 7 8 5}$ & \multicolumn{1}{c|}{ Cargo } \\
\hline England & 40 & $\begin{array}{l}\text { Beef, butter, hides, } \\
\text { pork, skins, cloth, } \\
\text { rum. }\end{array}$ & England & 23 & $\begin{array}{l}\text { Beef, butter, hides, } \\
\text { linen cloth, oats. }\end{array}$ \\
\hline Scotland & 33 & $\begin{array}{l}\text { Beef, cloth, pork, } \\
\text { hides, skins, } \\
\text { flaxseed, tallow, } \\
\text { tobacco, } \\
\text { merchants goods. }\end{array}$ & Scotland & 21 & $\begin{array}{l}\text { Beef, pork, butter, } \\
\text { hides, linen cloth, } \\
\text { yarn, oatmeal, } \\
\text { oats. }\end{array}$ \\
\hline Caribbean & 18 & $\begin{array}{l}\text { Beef, butter, pork, } \\
\text { herrings. }\end{array}$ & Europe & 9 & $\begin{array}{l}\text { Beef, butter, pork, } \\
\text { hides, salmon, } \\
\text { rum, brandy. }\end{array}$ \\
\hline American Colonies & 7 & $\begin{array}{l}\text { Beef, butter, pork, } \\
\text { cloth, malt, bread. }\end{array}$ & Ireland & 7 & $\begin{array}{l}\text { Flaxseed, iron, } \\
\text { flour, ashes, kelp. }\end{array}$ \\
\hline Europe & 4 & $\begin{array}{l}\text { Beef, butter, pork, } \\
\text { rum. }\end{array}$ & Caribbean & 5 & $\begin{array}{l}\text { Beef, pork, } \\
\text { herrings, salmon, } \\
\text { oats, linen cloth. }\end{array}$ \\
\hline unspecified & 2 & $\begin{array}{l}\text { Hides, skins. } \\
\text { Canada }\end{array}$ & America & $\begin{array}{l}\text { Linen cloth, beef, } \\
\text { potatoes, } \\
\text { merchants goods. }\end{array}$ \\
\hline
\end{tabular}

Source: Belfast News-Letter

The reports in the Belfast News-Letter show that as with the figures for Dublin there is a numerical trend downwards for importations into Belfast.

Once again the information from New Lloyd's List for vessel movements into the port of Belfast must be added to the data from the newspaper reports in order to make any accurate comparisons with the results of the Dublin research (see Table 2.10).

Normally numerical comparisons between Dublin and Belfast would not be made simply because of the per capita differences, but it is interesting to note that in 1770 more than three-times as many vessels departed the port of Dublin (373) than

\footnotetext{
${ }^{68}$ Arthur Young, A Tour in Ireland: with general observations on the present state of that kingdom: made in the
} years 1776, 1777, and 1778. And brought down to the end of 1779. 2 Vols. Vol. 1, London, 1780, pp.202-5. 
Belfast (105) in 1770, and twice as many in 1785 (Belfast 117, Dublin 234), even though Dublin's population is almost ten-times the size of that of Belfast. ${ }^{69}$

Table 2.9: Vessel movements inwards, Belfast, 1770 and 1785

\begin{tabular}{|l|c|c|l|c|c|}
\hline Country/Region & No. in $\mathbf{1 7 7 0}$ & $\mathbf{\%}$ of total & Country/Region & No. in $\mathbf{1 7 8 5}$ & \% of total \\
\hline England & $\mathbf{8 4}$ & $\mathbf{3 3 . 2} \%$ & England & $\mathbf{3 5}$ & $\mathbf{3 4 . 3 \%}$ \\
\hline Scotland & $\mathbf{7 9}$ & $\mathbf{3 1 . 2} \%$ & Europe & $\mathbf{1 9}$ & $\mathbf{1 8 . 6 \%}$ \\
\hline Europe & 34 & $13.4 \%$ & Scotland & 15 & $14.7 \%$ \\
\hline Ireland & 31 & $12.3 \%$ & Ireland & 14 & $13.7 \%$ \\
\hline Wales & 13 & $5.1 \%$ & Wales & 8 & $7.8 \%$ \\
\hline American Colonies & 10 & $4.0 \%$ & Caribbean & 6 & $5.9 \%$ \\
\hline unspecified & 2 & $0.8 \%$ & America & 4 & $3.9 \%$ \\
\hline & & & unspecified & 1 & $1.0 \%$ \\
\hline Total & $\mathbf{2 5 3}$ & $100.0 \%$ & Total & $\mathbf{1 0 2}$ & $100.0 \%$ \\
\hline
\end{tabular}

Source: Belfast News-Letter

Table 2.10: Vessel movements into Belfast, 1785 compared with vessel movements into Dublin, 1785

\begin{tabular}{|l|c|c|l|c|c|}
\hline \multicolumn{2}{|c|}{ 1785: Belfast News-Letter + New Lloyd's List } & \multicolumn{3}{|c|}{ 1785: Freeman's Journal + New Lloyd's List } \\
\hline Country/Region & $\begin{array}{c}\text { Movements } \\
\text { into Belfast }\end{array}$ & $\begin{array}{c}\mathbf{\%} \text { of } \\
\text { total }\end{array}$ & Country/Region & $\begin{array}{c}\text { Movements } \\
\text { into Dublin }\end{array}$ & $\begin{array}{c}\text { \% of } \\
\text { total }\end{array}$ \\
\hline England + Wales & $\mathbf{7 0 + 1 1}$ & & England + Wales & $\mathbf{3 5 1 + 3}$ & $\mathbf{5 6 . 3 \%}$ \\
\hline Europe & $\mathbf{5 6}$ & & Europe & $\mathbf{1 6 4}$ & $\mathbf{2 6 . 1 \%}$ \\
\hline Scotland & 36 & & Scotland & 50 & $7.9 \%$ \\
\hline America & 17 & & America & 34 & $5.4 \%$ \\
\hline Ireland & 14 & & Caribbean & 10 & $1.6 \%$ \\
\hline Caribbean & 14 & & Ireland & 6 & $1.0 \%$ \\
\hline & & & Other & 11 & $1.7 \%$ \\
\hline \multicolumn{2}{r|r|r|}{ Total } & $\mathbf{6 2 9}$ & $100.0 \%$ \\
\hline
\end{tabular}

Source: Belfast News-Letter and New Lloyd's List, 1785; Freeman's Journal and New Lloyd's List, 1785.

The contrast is even more dramatic when the figures for movements into Dublin and Belfast are considered; in 1785 the number of arrivals in Dublin is three-times

\footnotetext{
${ }^{69}$ Arthur Young records "the common computation of inhabitants [of Dublin] as 200,000" although he acknowledges "I should suppose exaggerated. Others guessed the number 140, or 150,000"; p.2. Modern historians such as Connell ('The Population of Ireland in the Eighteenth Century,' Economic History Review, Vol.16 no.2, 1946), O'Grada and Mokyr ('New Developments in Irish Population History, 1700-1850,' Economic History Review (New Series), Vol.37, no.1, November 1984) have all questioned Young's figures.
} 
that of Belfast - 629 for Dublin and 218 for Belfast. In summary, we have seen in the individual cases that the figures for vessel movements in and out of Dublin outstrip those of Belfast by a significant margin. In both cases the figures for 1785 are much lower than for 1770.

The explanation offered for these differences between 1770 and 1785 is the increase in the size of the vessels plying the waters; those in 1785 are significantly larger than their predecessors in 1770. The frequency therefore decreases even though production and export volumes may have increased in the interim; as the population of consumers has also increased in the intervening years, the import volumes increase but there is no need to increase the number of journeys, as the larger export vessels simply return with increased volumes of imports. Importantly, we can also see that although Belfast is numerically only one-tenth of the population size of Dublin, the port handles approximately four-times the volume of exports and imports per capita as Dublin. 
Chapter Three: Ireland's "Provisioning" Trade with England through the Port of Liverpool

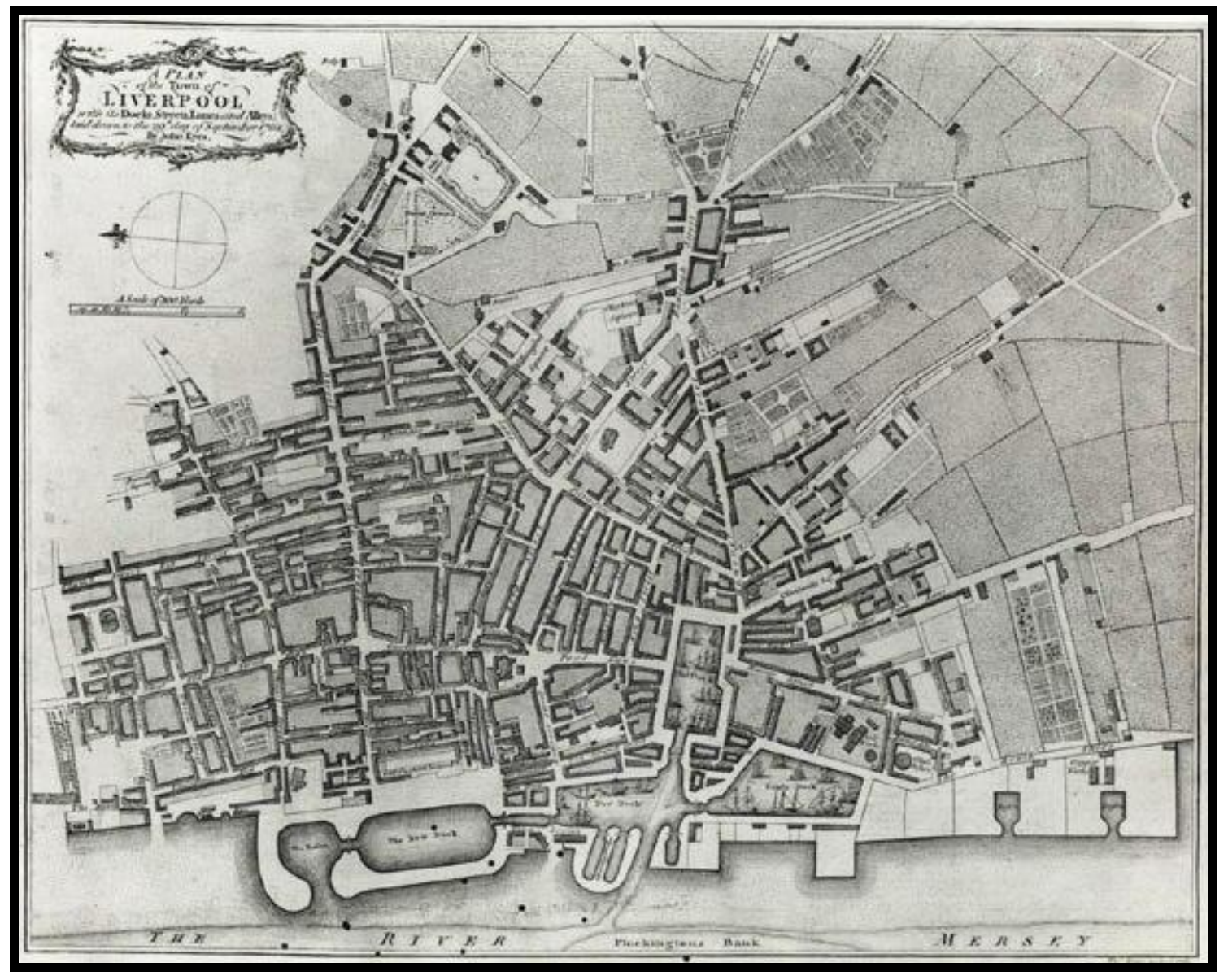


The analysis of Eaton's "List" and the shipping reports of the Freeman's Journal of Dublin, the Belfast News-Letter and New Lloyd's List in Chapters One and Two of this thesis support the following statements: in 1785 England was the largest market for Irish goods despatched from Dublin and Belfast (and the leading destination for vessels departing from those ports in 1785); England was also the largest supplier of goods to the domestic markets of Dublin and Belfast and the country of origin of the vast majority of the vessel movements clearing the custom houses inwards at Dublin and Belfast. While these are not new conclusions, the breakthrough has come in the level of detail of the maritime interaction between Dublin and Belfast and their mercantile partners in the British Isles, Europe and the Atlantic World. The micro-history was created for the year 1785 with information from sources not utilised before for this purpose.

A daily stream of coastal traders, colliers and mail packets plied their way across the Irish Sea and the focus of the first two chapters has been on goods moving in and out of Dublin and Belfast, the type of goods and where they were going to or coming from. Now in this third chapter, we examine the largest market — England and the "provisioning"71 of England by Irish producers - and the role Liverpool played in the mercantile interaction of Ireland and Britain. In the first section an overview of the increases in key commodities supplied by Irish producers to the English markets is presented and in the second, the facts and figures for the port of Liverpool are analysed.

\section{- I -}

As well as feeding a naturally increasing domestic population, Ireland also increased the volume of provisioning goods it exported. ${ }^{72}$ The English population was burgeoning; between 1750 and 1800 it increased by 46 percent from

\footnotetext{
71 "Provisioning" is the supply of the key commodities identified in Table 1.6, Chapter One, of this thesis. It includes primary produce and by-products, as well as linen goods. It does not include those items classified as "Merchants' goods."

${ }^{72} \mathrm{~K}$. H. Connell reported the Hearth Money Collectors' figure of 2,845,932 as the population of Ireland in 1785. K. H. Connell, 'The Population of Ireland in the Eighteenth Century' in Economic History Review, Vol. 16, no. 2, 1946, p.113. Brinley Thomas, 'Food Supply in the United Kingdom during the Industrial Revolution' in Joel Mokyr (ed.), The Economics of the Industrial Revolution, London, 1985, p.140, listed the population as 5,216,000 by 1801 .
} 
approximately 7.3 million to reach 10.7 million. ${ }^{73}$ Cullen commented that England provided "a much bigger outlet for Irish exports than the limited markets on the European mainland. Moreover, as English home production was far from adequate for the domestic demand...the relative importance of the Irish trade in the general pattern of English overseas trade increased sharply."74 The supporting evidence for this comes from several sources. In the following section we consider the commodities and then the changes in values of the goods.

Alice E. Murray compiled a list of twelve commodities (including several of those in Table 1.6 of this thesis) and tracked the quantities exported from Ireland over time. Data from her Table 1, Appendix B, are reproduced here in an abridged form to show the changes in the quantities or volume for nine of the commodities between 1770 and 1785 (see Table 3.1).

Table 3.1: Provisions exported from Ireland, 1770 - 1790

\begin{tabular}{|c|c|c|c|c|c|c|c|c|c|c|c|c|}
\hline \multirow{2}{*}{$\begin{array}{l}\text { Year } \\
\text { ended } \\
\text { Lady } \\
\text { Day }\end{array}$} & \multicolumn{2}{|c|}{ Bacon } & \multicolumn{2}{|c|}{ Beef } & \multirow[t]{2}{*}{ Butter } & \multirow[t]{2}{*}{$\begin{array}{c}\text { Calves } \\
\text { skins }\end{array}$} & \multirow[t]{2}{*}{ Cheese } & \multicolumn{2}{|c|}{ Hides } & \multirow[t]{2}{*}{ Pork } & \multirow[t]{2}{*}{ Tongues } & \multirow[t]{2}{*}{ Tallow } \\
\hline & Ham & Flitches & Barrels & Carcases & & & & Tanned & Untanned & & & \\
\hline & & No. & No. & No. & $C w t$ & Dozen & $C w t$ & No. & No. & Barrels & Dozen & $C w t$ \\
\hline 1770 & - & 6,500 & 208,269 & 55 & 262,717 & 19,255 & 1,815 & 28,187 & 102,943 & 43,947 & 4,198 & 48,260 \\
\hline 1775 & - & 32,644 & 192,452 & 10 & 264,140 & 23,803 & 1,953 & 56,890 & 79,892 & 50,367 & 4,620 & 42,495 \\
\hline 1780 & 203 & 1,723 & 187,754 & 16 & 244,184 & 17,908 & 960 & 13,182 & 68,777 & 96,554 & 5,114 & 54,592 \\
\hline 1785 & 720 & 35,485 & 136,650 & 166 & 282,802 & 28,954 & 1,312 & 19,623 & 57,293 & 58,445 & 3,806 & 21,240 \\
\hline 1790 & 1,836 & 56,494 & 126,993 & 14 & 300,669 & 25,226 & 293 & 1,626 & 73,134 & 100,266 & 3,571 & 16,717 \\
\hline
\end{tabular}

Source: Alice E. Murray, A History of the Commercial Relations between England and Ireland from the period of the Restoration, London, 1903 (reprinted New York, 1970), pp.135, Appendix B, Table 1, p.440.

In what has become a reference work for anyone studying England's overseas trade during the seventeenth and eighteenth centuries, Elizabeth Schumpeter collated export and import data for the period 1697 to $1808 .{ }^{75}$ Although she confined herself to the analysis of only a few commodities, the work she did do shows further evidence of the change over time. This interpretation of Schumpeter's figures comes

\footnotetext{
${ }^{73}$ By 1850 it had almost doubled to 21 million; Thomas, 'Food Supply' in Mokyr (ed.), The Economics of the Industrial Revolution, p.142.

${ }^{74}$ Cullen, Anglo-Irish Trade, p.46.

75 Elizabeth B. Schumpeter, English Overseas Trade Statistics, 1697-1808, Oxford, 1960.
} 
from T. S. Ashton in the 'Introduction' to the work. Table 3.2 reflects the percentage of total imports in each of nine categories examined by Schumpeter.

Table 3.2: Percentage of total imports into England

\begin{tabular}{|l|c|c|c|}
\hline Commodity & $\begin{array}{c}\text { Irish \% of total } \\
\text { imports into } \\
\text { England, 1700 }\end{array}$ & $\begin{array}{c}\text { Irish \% of total } \\
\text { imports into } \\
\text { England, 1750 }\end{array}$ & $\begin{array}{c}\text { Irish \% of total } \\
\text { imports into } \\
\text { England, 1800 }\end{array}$ \\
\hline Groceries $^{76}$ & 16.9 & 27.6 & 34.9 \\
\hline Linens & 15.6 & 14.8 & 5.6 \\
\hline Calicoes and piece & 5.9 & 5.3 & 4.5 \\
\hline Silk: raw and thrown & 6.3 & 3.5 & 2.4 \\
\hline Flax and hemp & 3.0 & 6.1 & 4.3 \\
\hline Cotton wool & - & 0.9 & 6.0 \\
\hline Dyestuffs & 1.0 & 1.5 & 4.2 \\
\hline Timber & 4.0 & 4.2 & 2.1 \\
\hline Wine & 10.8 & 4.7 & 2.4 \\
\hline
\end{tabular}

Source: abstracted from T.S. Ashton, 'Introduction', Elizabeth B. Schumpeter, English Overseas Trade Statistics, 1697-1808, Oxford, 1960, p.11.

Table 3.3: Liverpool: consignments arriving from Ireland stated in percentages Comparison 1770 to $1785^{77}$

\begin{tabular}{|l|r|r|}
\hline \multicolumn{1}{|c|}{ Of the consignments listed from Irish ports: } & \multicolumn{1}{c|}{$\mathbf{1 7 7 0}$} & \multicolumn{1}{c|}{$\mathbf{1 7 8 5}$} \\
\hline Barley & $0 \%$ & $4.2 \%$ \\
\hline Wheat & $0 \%$ & $3.4 \%$ \\
\hline Cow hides & $3.0 \%$ & $0.5 \%$ \\
\hline Pork & $3.1 \%$ & $1.6 \%$ \\
\hline Bay yarn & $3.2 \%$ & $4.7 \%$ \\
\hline Tallow & $5.3 \%$ & $0.8 \%$ \\
\hline Beef & $6.2 \%$ & $4.9 \%$ \\
\hline Butter & $15 \%$ & $18.4 \%$ \\
\hline Linen "cloth" & $23 \%$ & $20.5 \%$ \\
\hline Linen "yarn" & $27 \%$ & $11.4 \%$ \\
\hline
\end{tabular}

Source: Manchester Mercury

${ }^{76}$ The category 'Groceries' includes tea, coffee, sugar, rice, pepper and other produce such as spices from Africa and the Caribbean. In the latter half of the period, by far the largest amount of linen was imported from Ireland while calicoes and silk came via the East India trade in the main. Cotton arrived from the plantation colonies of America and the dyestuffs, increasingly in this period, from the Caribbean and Africa. Most of the timber came from the Baltic and Scandinavian countries and the wine from France and the Iberian Peninsula.

7750 issues (of the possible 52) of the Manchester Mercury contained printed lists of shipping information for 1785. 1,314 vessel movements were listed, 680 (or 52\%) listed goods discharged at Liverpool in detail; 634 (or $48 \%$ ) have no goods listed. 
After examining the information from the shipping reports, it is clear that the percentage figures for the types of goods imported changed quite significantly. In 1770, fifty percent of the goods were linen goods and then the next largest percentage is that of Beef at 6.2 percent followed by tallow at 5.3 percent. In 1785, 20.5 percent of the consignments were linen cloth, 11.4 percent linen yarn (still almost 32 percent of the total - but representative of an 18 percent decrease by consignment number), and 18.4 percent butter. Grain shipments account for 7.6 percent of the imports. Table 3.3 shows the change over time.

One of the clearest indications of growth over time in the value of the mercantile interaction between Ireland and Great Britain in all sectors is contained in Charles Whitworth's 1776 weighty tome with data collated "from the annual Accounts given in by the proper Officers to the House of Commons." He declared them to be "as authentic, and as accurate, as any that can be procured on the Subject." 78

Table 3.4: Value of Exports and Imports, Ireland and England, 1700 - 1800

\begin{tabular}{|c|r|r|l|}
\hline $\begin{array}{c}\text { For the } \\
\text { year }\end{array}$ & $\begin{array}{c}\text { Ireland } \\
\text { Exports to } \\
\text { England }\end{array}$ & $\begin{array}{c}\text { Ireland } \\
\text { Imports from } \\
\text { England }\end{array}$ & \multicolumn{1}{|c|}{ Source } \\
\hline 1700 & $£ 233,853$ & $£ 271,641$ & $\begin{array}{l}\text { Whitworth p.19 \& Cullen p.46-7; Exports } \\
£ 372,585 ; \text { Truxes, } p .260\end{array}$ \\
\hline 1750 & $£ 612,808$ & $£ 1,316,600$ & $\begin{array}{l}\text { Whitworth \& Cullen. Exports } £ 1,069,864 ; \text { Truxes, } \\
\text {.261. }\end{array}$ \\
\hline 1770 & $£ 1,214,398$ & $£ 2,125,467$ & $\begin{array}{l}\text { Whitworth \& Cullen. Exports } £ 2,408,839 ; \text { Truxes, } \\
\text { p.261. }\end{array}$ \\
\hline 1780 & $£ 1,549,388$ & $£ 1,930,338$ & Cullen. Exports $£ 2,384,899 ;$ Truxes, $p .261$. \\
\hline 1790 & $£ 2,203,099$ & $£ 1,937,538$ & Cullen. \\
\hline 1800 & $£ 2,445,079$ & $£ 3,786,085$ & Cullen. \\
\hline
\end{tabular}

Source: Whitworth, Cullen, Truxes ${ }^{79}$

\footnotetext{
${ }^{78}$ Whitworth, State of the trade, pp.2-3; T.S. Ashton, in his introduction to the published volume of Elizabeth Boody Schumpeter's English Trade Statistics, 1697-1808, points out however, that "merchants tended to under-declaration of the amounts of their shipments of things subject to duties, and to overdeclaration of the amounts of those that attracted bounties or drawbacks on re-export" (p.5). ${ }^{79}$ Figures abstracted from Whitworth, Cullen and Truxes. Francis James produced a different set of figures based on "Value of Trade of Ireland 1698-1767", examined by John Wetheral, in the Irish National Library. It is unclear whether the figures quoted are in $£ I R E$ or $£ S t g$ but according to his research Ireland imported goods to the value of $£ 428,000$ from Great Britain and exported $£ 373,000$ to Great Britain, for the year ending 25 December 1700. Despite the differences in figures, the trend is still the same - an expanding national economy. Francis G. James, Ireland in the Empire, 1688-1770: A History of the Williamite Wars to the Eve of the American Revolution, Cambridge, Mass., 1973, Appendix XII (fn 35), p.198.
} 
Table 2.5 in Chapter Two of this thesis contained the summary of Whitworth's export and import figures between Ireland and England but these have been challenged by later historians. For example, Thomas Truxes presented another set of figures - total Irish exports for 1700 equal $£$ Stg 814,746, £Stg 372,585 of which represents the value of exports to 'Great Britain', £Stg 1,862,834 total in 1750 ( $£$ Stg $1,069,864$ to Great Britain) and a total of $£ S \operatorname{tg} 3,159,587$ in 1770 — $£$ tg 2,408,839 for Great Britain alone. Table 3.4 shows the changes in the value of exports and imports moving to and from Ireland at various times during the period 1700 to 1800 .

Charles Whitworth's figures (corroborated by Elizabeth Schumpeter's research) show that the value of goods increased rapidly in the eighteenth century examined. Thomas Ashton and Louis Cullen modified these data later. Certainly, the market share, as noted by Ashton, ${ }^{80}$ increased at the same time, but we cannot say the same about the market share for 1770 and 1785 . While the number of individual shipping movements into Liverpool from Ireland increased slowly, and the number of individual consignments increased quite considerably, the percentage of market share of Irish goods remained relatively static. The possible explanation for this increase in the value must lie, therefore, in an increase of volume and quantity or prices or any number of combinations of both factors.

Table 3.5: Increased Exports from Ireland to Great Britain, 1770 - 1790

\begin{tabular}{|c|c|c|c|}
\hline $\begin{array}{c}\text { Year ended 25 } \\
\text { March }\end{array}$ & $\begin{array}{c}\text { Exports to Great } \\
\text { Britain }\end{array}$ & Exports to all parts & $\begin{array}{c}\text { Great Britain as \% of } \\
\text { total }\end{array}$ \\
\hline 1770 & $£ 2,408,839$ & $£ 3,159,587$ & $76.2 \%$ \\
\hline 1780 & $£ 2,384,899$ & $£ 3,012,179$ & $79.2 \%$ \\
\hline 1790 & $£ 3,695,670$ & $£ 4,855,319$ & $76.1 \%$ \\
\hline
\end{tabular}

Source: Table 9; Cullen, Anglo-Irish Trade, p.45.

Louis Cullen's study of Anglo-Irish Trade between 1660 and 1800 included a chapter on volume and growth where he stated that value of Irish exports to Great Britain rose 85.4 per cent between 1740 and $1800 .{ }^{81}$ Table 3.5 is abstracted from Cullen's Table 9.

\footnotetext{
${ }^{80}$ Ashton noted that "the share of Ireland in shipments to England rose from under 1 per cent in 1700 to 18 per cent in $1750 \ldots$ and 70 per cent in 1800 ". T. S. Ashton, 'Introduction', p.12.

${ }^{81}$ Cullen, Anglo-Irish Trade, p.46.
} 
With clear evidence of the increase, not only in the total volumes and quantities but in values, of the goods exported from Ireland gathered from multiple sources, we turn our attention to two of the specific key commodities from Table 1.6 (Chapter One of this thesis). One example is that of the changes in the production and export of butter and the second example is that of linen.

The data collated from the Manchester Mercury indicate that 1,409,132lbs of butter arrived in Liverpool from Ireland with about 451,640lbs from Belfast and $24,388 \mathrm{lbs}$ from Dublin. The figure for Belfast represents 33 percent of the total arrived in Liverpool and Dublin just two percent; Belfast is by far the largest supplying port and Dublin is only ranked seventh of the sixteen ports listed. ${ }^{82}$

Alice Murray concluded that the increasing tendency in Ireland to "turn large tracts of land into pasture" during the latter part of the eighteenth century resulted in a marked increase in the amount of land utilised for grazing and dairy. She concluded that "pasture farming required little skill [and]...little capital." Her figures show that in 1770 a total of $262,717 \mathrm{cwt}(29,420,000 \mathrm{lbs})$ of butter was exported from Ireland; Brinley Thomas cites Cullen's figure of 114,363cwt $(12,810,000 \mathrm{lbs})$ of butter exported to Great Britain. ${ }^{83}$

The shipping reports of the Manchester Mercury for 1785 show a total of $1,860,204 \mathrm{lbs}$ of butter arrived in Liverpool from Ireland. Of this figure, approximately 1,240,7081bs arrived from Belfast while the figure for Dublin totalled approximately $48,132 \mathrm{lbs}^{84}$ Thus, 68 percent of the butter arrived in Liverpool came from Belfast and a little less than three percent came from Dublin. Belfast is the leading port of export of butter to Liverpool, and Dublin is ranked fifth of the

\footnotetext{
82 Totals calculated by this author from a transcription of the goods reported arrived in Liverpool in the available issues of the Manchester Mercury. Conversion from firkins, barrels, half-firkins etc carried out with the use of: Anthony Zupko, A dictionary of English weights and measures; from Anglo-Saxon times to the nineteenth century, Wisconsin, 1968. In descending order - Cork 274,008lbs, Sligo 185,248lbs, Waterford 162,288lbs, Newry 118,832lbs, Coleraine 19,376lbs, Loughlarne 14,840lbs, Donaghadee, Larne, Drogheda, Londonderry, Dundalk, Carrickfergus, and Wexford all exported less than 10,000lbs each.

${ }^{83}$ Alice E. Murray, A History of the Commercial Relations between England and Ireland from the period of the Restoration, London, 1903 (reprinted New York, 1970), pp.135, Appendix B, Table 1, p.440. Young, A Tour in Ireland, reported 201,510cwt of butter exported in 1770 but the source of this data is unknown. As Alice Murray used the Custom House Books to collate her data, this information will be utilised by this author for the purposes of this thesis. Thomas, 'Food Supply' in Mokyr (ed.), The Economics of the Industrial Revolution, p.142 cites Cullen, Anglo-Irish Trade, p.70.

${ }^{84}$ Young, A Tour in Ireland, 1780
} 
twelve ports listed. ${ }^{85}$ The exports from Belfast equate to a 250 percent increase in the amount of butter leaving that port in 1770 compared to that leaving in 1785 .

Murray's figures for 1785 show a total 282,802cwt $(31,670,0001 \mathrm{bs})$ butter exported from Ireland - an increase of approximately ten percent over the figure for 1770 - and Thomas cites Cullen's figure of 159,526cwt (17,870,000lbs - which equates to an approximate increase of 40 percent over the 1770 figures) to Great Britain. ${ }^{86}$

Clearly, whichever of the sets of figures one uses as an indicator of growth — either published by others or collated by this author — all information points to a dramatic increase in animal numbers and improvements in animal husbandry in fifteen years. A similar increase occurred from 1755 to 1770. As reported by Arthur Young 180,980 barrels of beef, 223,294cwt of butter, 154,184 hides and 26,029cwt of tallow exported from Ireland in 1755 and 208,269 barrels of beef, 201,510cwt of butter, 131,130 hides and 48,260cwt of tallow shipped fifteen years later, in $1770 .{ }^{87} \mathrm{~A}$ small downturn occurred in butter and hides but the other indicators show increases. Young also considered exports of pork - reporting 20,930 barrels exported in 1755 and 42,947 in 1770 with a steady increase through to the end of his figures in 1777 (72,931 barrels). ${ }^{88}$ Add to this series of data from Young, the figures from the Manchester Mercury that show butter imports into Liverpool alone, from Ireland in 1785, topped 475,000 lbs (over 230 tonnes)..$^{89}$

Data gathered from Eaton's "List" also supports increased provisions exports. For the first quarter of 1785, all 2,888 bacon flitches, 1,596cwt of flour, 144cwt of kelp, 5,731 great stones of bay yarn left Dublin destined for English ports; only $60 \mathrm{cwt} 2 \mathrm{qr}$ of the total of $1,415 \mathrm{cwt} 1 \mathrm{qr} 6 \mathrm{lb}$ of tallow went to a non-English port and that went to Scotland. ${ }^{90}$ Arthur Young's list shows 6,500 flitches of bacon

\footnotetext{
${ }^{85}$ In descending order - Newry 260,568lbs, Cork 154,952lbs, Larne 88,676, Sligo 19,376lbs and Limerick, Strangford, Waterford, Donaghadee, Drogheda and Coleraine each with less than 10,000lbs.

${ }^{86}$ Between 1760 and 1790 imports of butter from Ireland increase six-fold, beef three-fold and pork seven-fold (p.141); Thomas, 'Food Supply' in Mokyr (ed.), The Economics of the Industrial Revolution, p.142 cites Cullen, Anglo-Irish Trade, p.70.

87 A. W. Hutton (ed.), Young's Tour in Ireland, London, 1892, p.170.

${ }^{88} \mathrm{Ibid}, \mathrm{p} .177$; He lamented the lack of understanding about successfully growing cereal crops, but praised the ingenuity of the poorer classes in pasturing other people's animals where they have a "deficiency" in pasturage at home.

${ }^{89}$ Clearly the value of the goods from Ireland increased, and now we have figures to show volume also increased.

90 Calculations carried out by this author from Eaton's "List."
} 
exported in total for $1770 .{ }^{91}$ Murray's figures corroborated Young's flitches figures for 1770 so the assumption is that Great Britain took all of Ireland's production of bacon flitches. Murray shows a total of 43,947 barrels of pork exported in 1770 and the figures presented by Young several decades earlier are the same. Murray presented series data for twelve commodities for the years 1764 to 1800 and it is clear that, as with Young's figures, the trend for the staple commodities is upward. ${ }^{92}$

Let us now consider the second of our examples - one of the other key commodities exported from Ireland, namely linen cloth. Cullen concluded that "imports of linen and linen yarn [into England from Ireland]...increased over the 1770 s as a whole, and by a further 50 per cent in the 1780 s." The Irish linen industry enjoyed a comparative advantage because of low-cost labour. The cost of spinning yarn in Ireland was only two-thirds the cost of spinning in England. ${ }^{93}$ The quality of flax proved less important; indeed Irish merchants imported flax from the MidAtlantic region of North America.

For the year ending 25 December 1770, England imported 19.6 million yards of linen from Ireland; ten years later the figure was slightly lower at 18.2 million yards but as a proportion of total exports that still represented about 99.5 per cent of the total quantity exported. By 1790, the figure had risen to 33.3 million yards but the percentage fell to just over 90 per cent of the total exported. ${ }^{94}$ The figures from the shipping reports of the Manchester Mercury for 1770 show that a total of 1,533,650 yards of linen cloth arrived in Liverpool from Ireland; 44 percent of the total arrived from Dublin (677,500 yards) and 167,225 yards or 11 percent from Belfast. Dublin ranked highest with Belfast fourth; Newry ranked second and Drogheda third. Strangford, Londonderry and the other minor ports only exported five percent of the total received in Liverpool.

\footnotetext{
${ }^{91}$ Hutton, Young's Tour in Ireland, p.177; Murray, A History of the Commercial Relations between England and Ireland, p.440 shows a figure of 6,500 for the year ended Lady Day, 1770 transcribed from the Custom House Books in the National Library of Dublin.

92 Truxes, Irish-American Trade, shows 12,090 of the total of 43,948 barrels of pork exported to Great Britain in 1770.

${ }_{93}$ Cullen, Anglo-Irish Trade, p.49.

94 Table 16; ibid, p.60.
} 
In $1785,1,411,400$ yards of linen cloth arrived from Ireland into the port of Liverpool. Of that total 41 percent arrived from Dublin and 29 percent from Belfast. Belfast now ranked second only to Dublin. Of the remaining 30 percent of the total, Drogheda exported 26 percent and all other ports contributed four percent to the total. 95

From 1770 to 1785 Irish merchants shipped increasing percentages of goods to English markets. There were core commodities - beef, butter, linen - and the market value, current prices and/or volume varied each year. Analysis of consignments listed in the Manchester Mercury reinforced the conclusions drawn by others who based their analysis on the 'official' documents. ${ }^{96}$ The analysis of the shipping reports of goods departing Dublin and Belfast for England confirmed England as the key market for Irish goods. Of all the ports in England identified in the reports, Liverpool received the vast majority. In the second part of this chapter on the "provisioning" of England, we will examine the role Liverpool played in the mercantile and maritime interaction of Ireland and England in 1785.

\section{- II -}

As early as the 1670s Liverpool began to evolve into a major entrepôt. The sleepy, insignificant port suddenly became important as a port of lading in the AngloAmerican, African and Caribbean trades. With the growth of the tobacco and sugar trades and the ensuing fall in prices as the commodities arrived in increasing quantities, the merchants needed to make significant savings in costs to remain viable. The extra distance of travelling to unload in London diminished the returns and west coast ports such as Bristol, Liverpool, and Whitehaven became more attractive. Their facilities, however, were not. Therefore, in the latter decades of the seventeenth and early decades of the eighteenth century these ports underwent major redevelopment to attract and accommodate the needs of the merchants,

\footnotetext{
${ }_{95}$ Manchester Mercury shipping reports - quantities tallied by this author.

${ }^{96} \mathrm{I}$ am confident, therefore, that the use of the newspaper reports as a source of information is acceptable.
} 
exporters and importers. By 1750 infrastructure improvements enabled Liverpool to become the second largest port in England in terms of volume and value of its Anglo-American trade but also an extremely important port in the mercantile interaction of Ireland and England. ${ }^{97}$

William Enfield's Liverpool history written in 1774, describes the great improvements to Merseyside's docklands thus:

The CUSTOM-HouSE, conveniently situated at the east end of the Old Dock, is a neat brick building, ornamented at angles and windows with stone. A small flight of steps in the front leads to an open lobby or piazza, above which is the Long Room, or chief place for transacting the business of the Customs, with other offices. Behind the building is a spacious yard with proper warehouses; except that for India goods, ${ }^{98}$ which is complained of as much too small for the purpose.

Enfield continued with a description of the Docks. He noted that "There are five public Docks; three of which are so constructed with flood-gates, as to inclose [sic] a sufficient depth of water to keep the ships afloat, in all times of the tide...the great advantage of these Docks can only be seen by comparing the ease and convenience with which business is done at Leverpool, with the labour, hazard and delay which attend the landing and unlading of goods at London, Bristol, and other great ports which have no such receptacles." The three Docks (South, Old and North), along with the 'Dry Dock' and the 'New Dry Dock' meant the port boasted 2,666 yards of Quays and these were in almost constant use. The so-called 'wet-docks' were used by "such ships as go foreign voyages" and the 'dry-docks' by "those vessels which are employed coast-wise" ${ }^{99}$

Several factors explain Liverpool's commercial growth. ${ }^{100}$ Lancashire industrialisation produced goods surplus to the domestic market, and manufacturers sought offshore markets. It made economic sense to develop the

\footnotetext{
${ }^{97}$ Richard Brooke, solicitor, notary and antiquarian, described the Irish trade as "also one of some magnitude and importance to Liverpool." Richard Brooke, Liverpool as it was [during the Last Quarter of the Eighteenth Century,]: 1775-1800, Liverpool, 1853 (revised edition, 2003).

98 This comment is of interest, although not strictly relevant to this thesis; it provides an explanation for the reasons why India goods were housed in London warehouses.

${ }_{99}$ William Enfield, An essay towards the history of Leverpool, drawn up from papers left by the late Mr George Perry..., London, 1774, pp.59-60.

100 Paul G. E. Clemens, 'The Rise of Liverpool, 1665-1750', Economic History Review (New Series), Vol.

29, no. 2, May 1976, pp.211-25.
} 
nearest port to cater for the increased maritime traffic required to move those goods offshore. Liverpool merchants were keen also to exploit the geographic advantage the port held it during wartime. It made strategic sense to move as much product through Liverpool as possible. Vessels leaving the port of Liverpool quickly rounded the northeast coastline of Ireland and headed into the open water of the North Atlantic - often avoiding the French, who found it difficult to be everywhere at once along the long, rugged Irish coastline.

Liverpool took control of the American and West Indian trade, as Bristol lost its earlier dominance and the expansion continued at pace in the eighteenth century. ${ }^{101}$ Finally, the proximity to Ireland made it an ideal destination and distribution point for the provisions needed by the domestic market of the west coast of Britain and Scotland and colonial residents in the American Colonies and the West Indies.

Figures from the returns of the Collectors of Customs show that in 1785, 1,427 British and 129 foreign vessels arrived at Liverpool. The gross receipts from the revenue of customs for the 1785 equalled $£ 680,93819$ s $10 \mathrm{~d}$ with the nett figure of $£ 264,771$ 5s 8d paid into the Exchequer. The amount of dock duties paid in 1785 was only $£ 8,4115$ s $3 \mathrm{~d}$ and the number of vessels that docked in 1785 numbered 3,429.102

In the first quarter of 1785, according to Eaton's "List," over 40 percent of the goods despatched from Dublin to an English port, that is, 121 consignments, were destined for Liverpool. For the full 1785 year the data from the Freeman's Journal and New Lloyd's List show 31 vessels cleared customs outwards from Dublin destined for Liverpool. Of the other 119 entries on the lists, 78 vessel movements had no destination specified; it would be reasonable to assume that at least 40 percent of them would be heading for Liverpool.

The Belfast News-Letter listed 16 vessels as departed from Belfast in 1785 with their destination set as Liverpool. A further 59 vessel movement outwards are merely listed as 'vessels,' 'colliers,' or 'coasters.' As the shipping reports indicated

\footnotetext{
${ }^{101}$ Kenneth Morgan, Bristol and the Atlantic trade in the eighteenth century, Cambridge, 1993.

102 Brooke, Liverpool as it was, pp.250-1.
} 
26 arrivals at Liverpool from Belfast, information from the New Lloyd's List provided the details for the ten 'missing' voyages.

\section{Illustration 3.1: Port News from the Manchester Mercury}

[The entry for the arrival of the vessel Henry from Dublin is marked by the arrow]

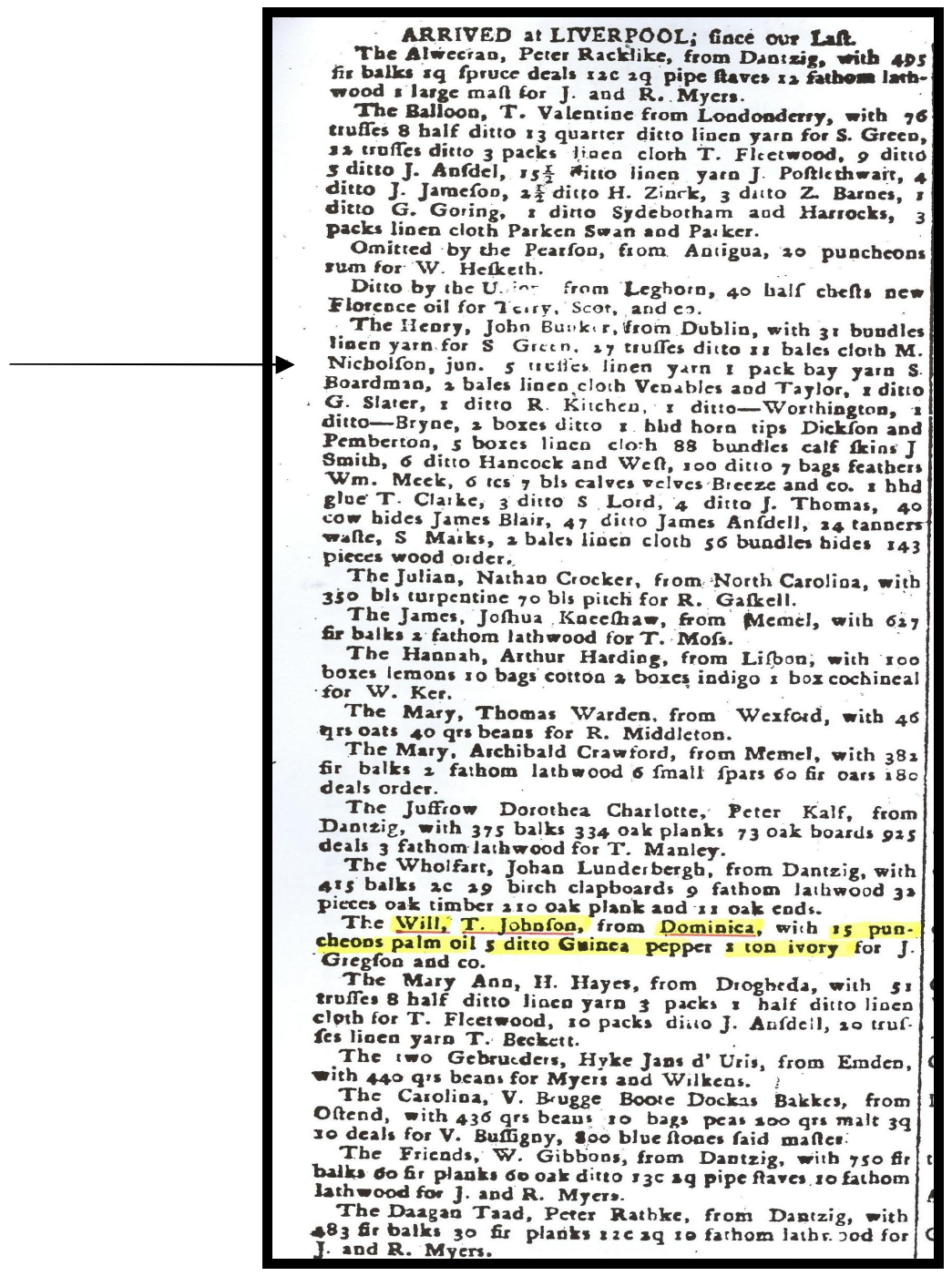

Source: Manchester Mercury, 1785.

The main source of information about the arrivals and departures into and out of Liverpool is the newspaper Manchester Mercury. It was published twice-weekly, on a Tuesday and a Friday and contained detailed lists of vessels, consignments and consignees or consignors. ${ }^{103}$ An example is inserted as Illustration 3.1.

\footnotetext{
${ }^{103}$ As with the shipping news reports in the other newspapers, there are variations in the amount of information contained in each report. In some instances particular parts of the entry are missing, for example, the port they were destined for or had come from, the goods carried out or inwards, the captain's name, or the consignee/consignor. Nevertheless a reasonable sized sample was obtained for analysis.
} 
Table 3.6: All shipping movements into Liverpool, 1785

[with and without details of goods]

\begin{tabular}{|l|c|c|}
\hline Country/Region of Origin & Frequency & $\mathbf{\%}$ of total \\
\hline England + Wales & $\mathbf{4 2 5 + 1 2 9}$ & $\mathbf{4 2 . 1 \%}$ \\
\hline Ireland & $\mathbf{2 8 7}$ & $\mathbf{2 1 . 8 \%}$ \\
\hline Europe & 171 & $13.0 \%$ \\
\hline Caribbean & 127 & $9.7 \%$ \\
\hline Scotland & 88 & $6.7 \%$ \\
\hline America & 63 & $4.8 \%$ \\
\hline Africa & 9 & $0.7 \%$ \\
\hline Unspecified & 8 & $0.6 \%$ \\
\hline Canada & 6 & $0.5 \%$ \\
\hline Southern Fisheries & 1 & $0.1 \%$ \\
\hline & $\mathbf{1 , 3 1 4}$ & $100.0 \%$ \\
\hline
\end{tabular}

Source: Manchester Mercury

Analysis of the Manchester Mercury shipping reports showed that for the full year of 1785 there were 1,314 individual shipping movements recorded into the port of Liverpool. ${ }^{104}$ Table 3.6 refers. Of the reports in the newspaper just over half (680 vessel movements or 52 percent) have 'goods discharged at Liverpool' listed in detail. The largest proportion of that number (425 vessel movements or 32.3 percent) arrived from another English port. This result is not surprising simply because coastal shipping had cost advantages over using roads or canals. The volume of goods that could be moved from port to port by coaster outstripped the quantity or volume that could be moved in one shipment by cart or barge. The coasters travelled at about five knots per hour with sufficient wind and covered between 100 and 125 miles per day. ${ }^{105}$

Much is made of Liverpool's trade with Africa and the majority of the historiography of the trade into and out of Liverpool and the merchant community of Liverpool focus on its participation in the "triangular trade" (slave trade). It is interesting to note here that in 1785 only nine vessels arrived in Liverpool from

\footnotetext{
${ }^{104}$ Brooke, Liverpool as it was; Brooke's figure of approximately 3,300 'vessels' paying dock duties in 1785 would indicate that the Manchester Mercury probably only reported the arrival of vessels discharging dutiable goods or those that required enumeration rather than total shipping which would also include passenger or mail vessels or other vessels or cargoes. As the figures were recorded for the year ended 24 June, the average of the 1785+1786 figures were used for the respective calendar years. ${ }^{105}$ John Armstrong, 'The Significance of Coastal Shipping in British Domestic Transport, 1550-1830', International Journal of Maritime History, Vol. 3, no. 2, December 1991, p.83.
} 
"Africa." In reality the statistics show that, for example, in 1770 Great Britain imported $£ 68,449$ 13s $7 \mathrm{~d}$ worth of goods from Africa -0.2 percent of the total $£ 12,216,93714 \mathrm{~s} 3 \mathrm{~d}$ - while the figure for Ireland is $£ 1,214,3984 \mathrm{~s} 5 \mathrm{~d}$ (equalling a little under ten percent of the total). For the same year the figure for exports to Africa totalled $£ 571,003$ 6s $9 \mathrm{~d}$; the figure for Ireland is $£ 2,125,46612 \mathrm{~s} 8 \mathrm{~d}$ - a figure four times that of the highly publicised African goods. ${ }^{106}$

The next largest group (287 vessel movements or 21.8 percent of the total) arrived in Liverpool with an Irish port listed as their last port of lading; 31 vessels arrived from Dublin and 26 from Belfast. Neither port is ranked first or second; Dublin lies third on the list and Belfast fifth. ${ }^{107}$ The 287 individual vessels movements brought 1,511 consignments of goods to Liverpool for sale or re-export; 10.8 percent of those consignments left from the port of Dublin and 9.7 percent from the port of Belfast.

Table 3.7 is a list of the vessels from Belfast along with information from the newspapers as to what cargo they were carrying and Table 3.8 lists the vessels arrived in Liverpool from Dublin for the full 1785 year:

This section has detailed the vessel movements into Liverpool from Dublin and Belfast collated from the shipping reports of the Manchester Mercury for 1785 with some comparison to the figures for 1770. As the newspaper included the details of the consignments inwards it has been possible to analyse the quantities and volumes of goods arriving from Ireland. In Chapter One and Chapter Two of this thesis the results of my analysis of the goods exported from Ireland showed that three main categories of goods were despatched - Primary produce and Byproducts (with seven key commodities), Linen yarn and Linen products, and Merchants' goods (a category covering the miscellaneous items that did not fall into

\footnotetext{
106 Whitworth, State of the Trade, p.74.

107 Wexford ranked first with 17.4 percent of the vessel movements and Drogheda ranked second with 11.1 percent. The difference between Drogheda and Dublin at 0.3 percent is negligible; Cork lies fourth with 10.1 percent. The top five ranked ports of lading account for 59.1 percent of the number of vessel movements. A shortage of grain in England in the mid-1780s led to large imports from Ireland and the majority of the goods imported from Wexford into Liverpool in 1785 was oats and also included one shipment of ten tons of oatmeal shipped on board the Jenny in May 1785. Oats, barley and wheat came from Drogheda along with thousands of yards of linen cloth and hundreds of trusses of linen yarn.
} 
the other two categories). ${ }^{108}$ These categories are still applicable to any discussion about the arrivals in Liverpool.

Table 3.7: Vessel arrivals in Liverpool from Belfast, 1785

\begin{tabular}{|c|c|c|c|}
\hline & Vessel & Captain & Goods \\
\hline 1785.01 .04 & New Draper & Crawford, P. & Linen cloth, beef, butter \\
\hline 1785.01 .25 & Liberty & Lepper, Dollaway & Butter, linen cloth, pork, mess beef \\
\hline 1785.02 .22 & New Draper & Crawford, P. & Linen cloth, butter, beef, pork \\
\hline 1785.03 .22 & Hillsborough & McIlroy, James & Wheat \\
\hline 1785.04 .12 & New Draper & Crawford, P. & Butter \\
\hline 1785.08 .09 & Chance & McIlroy, John & Butter, linen cloth, beef, glue \\
\hline 1785.08 .09 & New Draper & Crawford, pat. & Butter \\
\hline 1785.08 .23 & Liberty & Lepper, Dolloway & Beef, linen cloth \\
\hline 1785.09 .06 & Robert & McCalpin, Wm. & Butter \\
\hline 1785.09 .20 & New Draper & Crawford, Patrick & Linen cloth, butter \\
\hline 1785.09 .20 & Robert \& Betty & Curry, Thos. & Butter \\
\hline 1785.10 .04 & Liberty & Lepper, Dolloway & Butter, beef, linen cloth, hides, ox horns \\
\hline 1785.10 .25 & Hillsborough & English, John & Butter \\
\hline 1785.10 .25 & Robert & McAlpin, Wm. & Butter \\
\hline 1785.11 .08 & New Draper & Crawford, P. & Beef, linen cloth, ox hides, butter \\
\hline 1785.11 .15 & Catherine & Roberts, Jn. & Barley \\
\hline 1785.11 .22 & Fame & Harrison, J. & Barley, oats \\
\hline 1785.11.22 & Liberty & Lepper, Dolloway & Butter, linen cloth \\
\hline 1785.11 .22 & William $\mathcal{E}$ John & McNamara, P. & Butter \\
\hline 1785.12 .06 & Hillsborough & Mazier, John & Cloth, butter, beef, \\
\hline 1785.12 .06 & Mary & Brown, Neil & Barley \\
\hline 1785.12 .13 & Speedwell & Hamilton, Gavin & Butter, beef \\
\hline 1785.12 .27 & Nancy & McLean, D. & oats \\
\hline
\end{tabular}

Source: Manchester Mercury

The possibilities of analysing vessel movements outwards from Liverpool to Ireland were hampered because the shipping news reports of the vessel movements out of Liverpool in the Manchester Mercury were sporadic and lacking enough detail to include in the database. Thus to reconstruct possible scenarios for the missing data, the shipping information for vessel movements outwards from Dublin to Liverpool and Belfast to Liverpool was collated from the Freeman's Journal, Belfast News-Letter, and New Lloyd's List. By using the Manchester Mercury arrivals inwards, the possibilities of identifying "shipments" increased significantly. More importantly, it

108 Refer Table 1.6 in Chapter One of this thesis. 
Table 3.8: Vessel arrivals in Liverpool from Dublin, 1785

\begin{tabular}{|c|c|c|c|}
\hline & Vessel & Captain & Goods \\
\hline 1785.01.18 & Jennett \& Jane & White, Robert & Wheat, beans \\
\hline 1785.02 .01 & Active & Brown, George & Hams, linen cloth, feathers, beef, skins \\
\hline 1785.02 .01 & Hannah & Marks, S & $\begin{array}{l}\text { Linen yarn, bay yarn, linen cloth, tallow, beef, pork, ox horns, } \\
\text { coney wool, beef, ox hides, cow hides, beef, rapeseed, feathers, } \\
\text { greaser butter, grease, hams, rozin, old gun barrels, locks }\end{array}$ \\
\hline 1785.02 .08 & Peggy & Corkron, A. & $\begin{array}{l}\text { Tallow, linen yarn, hams, beef, coney wool, furriers waste, } \\
\text { quills, calf skins, beef, tongues, pork, bacon, feather beds }\end{array}$ \\
\hline 1785.03 .08 & Glory & Shaw, Norman & Wheat, flower, pork, shumack, bacon \& hams \\
\hline 1785.03 .08 & Mary & Scott, James & Linen cloth, hams \\
\hline 1785.04 .05 & Active & Simmons, Thos. & Linen yarn, linen cloth, skins, beef, pork, bacon, quills \\
\hline 1785.04 .05 & Peggy & Corkron, A. & Linen yarn, bay yarn, furriers waste, feather beds \\
\hline 1785.04 .12 & Hannah & Marks, S. & $\begin{array}{l}\text { Flour, bacon, kip skins, beef, tongues, linen yarn, bay yarn, } \\
\text { linen cloth, coney wool, butter, wafers, herrings, hams, feathers }\end{array}$ \\
\hline 1785.05 .10 & Glory & Gillis, A & $\begin{array}{l}\text { Linen yarn, bay yarn, drapery, wool, butter, corks, glue, } \\
\text { brimstone, salted skins, dry skins, pork, feathers, ox horns, } \\
\text { hides, raisins, bacon, hams, pork, calves skins, linen cloth }\end{array}$ \\
\hline 1785.05 .24 & Henry & Bunker & Linen yarn, bay yarn, butter, hams, bacon, feathers, calf skins \\
\hline 1785.05 .31 & Active & Brown, Gwyn & Linen yarn, linen cloth, glue \\
\hline 1785.07.07 & Hannah & Marks, Simon & $\begin{array}{l}\text { Beef, linen yarn, bay yarn, linen cloth, calf skins, oatmeal, } \\
\text { bacon, kip \& calf skins, linen tape, butter, glue, feathers, hogs } \\
\text { lard, bacon, hams, furriers waste }\end{array}$ \\
\hline 1785.07.12 & Henry & Bunker, John & $\begin{array}{l}\text { Linen cloth, linen yarn, bay yarn, calf skins, tallow, ox horns, } \\
\text { glue, beef, wool card }\end{array}$ \\
\hline 1785.07.12 & Union & Cummens, Wm. & No goods stated \\
\hline 1785.07.19 & Henry & Bunker, John & No goods stated \\
\hline 1785.08 .02 & Glory & Gillis, A & $\begin{array}{l}\text { Linen yarn, bay yarn, wool cards, empty casks, beef, dried } \\
\text { skins, glue, bacon \& hams, safflower, ox horns, calves velves, } \\
\text { linen cloth }\end{array}$ \\
\hline 1785.08 .09 & Hannah & Marks, Simon & $\begin{array}{l}\text { Beef, linen yarn, bay yarn, feathers, linen cloth, calf skins, } \\
\text { hides, kip skins, feathers, glue, lemons, quills }\end{array}$ \\
\hline 1785.09 .06 & Fame & Shaw, N, & Linen yarn, bay yarn, linen cloth, wine, calf skins \\
\hline 1785.09 .13 & Glory & Gillis, A. & Linen cloth, beef, hides \\
\hline 1785.09 .27 & Henry & Bunker, John & $\begin{array}{l}\text { Linen yarn, bay yarn, butter, glue, feathers, rapeseed, calves } \\
\text { velves, hides }\end{array}$ \\
\hline 1785.10 .04 & Hannah & Marks, Simon & $\begin{array}{l}\text { Beef, tongues, rapeseed, linen yarn, bay yarn, feathers, dry kip } \\
\text { \& calf skins, salted kip skins, beef, sacks, horns, bacon }\end{array}$ \\
\hline 1785.10.11 & Active & Simmons, Thos. & Linen cloth, bay yarn, linen yarn, dried skins, corkwood, butter \\
\hline 1785.10.11 & Peggy & Corkran, A. & $\begin{array}{l}\text { Linen cloth, butter, bay yarn, coney wool, furriers waste, calf } \\
\text { skins, hides, quills, oatmeal, feathers, glue, waste, green calf } \\
\text { skins, beef, linen yarn }\end{array}$ \\
\hline 1785.10.18 & Three Brothers & Brown, George & $\begin{array}{l}\text { Linen cloth, ox horns, butter, bay yarn, linen yarn, dry skins, } \\
\text { salt hides, beef, tongues }\end{array}$ \\
\hline 1785.11.08 & Henry & Bunker, John & $\begin{array}{l}\text { Linen cloth, apples, bacon, butter, dry skins, linen yarn, bay } \\
\text { yarn, lambs wool, tallow, hides, rapeseed, beef }\end{array}$ \\
\hline 1785.11 .08 & Union & Cummens, W. & $\begin{array}{l}\text { Linen cloth, quills, prunes, linen yarn, linen cloth, apples, beef, } \\
\text { tallow, feathers, rabbits fur, hides, kip \& calf skins, trunks }\end{array}$ \\
\hline 1785.11.15 & Huddersfield & Grice, W. & Beef, tongues \\
\hline 1785.12 .06 & Glory & Gilles, A. & $\begin{array}{l}\text { Linen yarn, linen, beef, tallow, glue, calf skins, cow hides, } \\
\text { chandlers greaves, hides, rabbits pelts, bacon, hams, butter }\end{array}$ \\
\hline 1785.12 .13 & Brothers & Brown, G. & $\begin{array}{l}\text { Beef, glue, rapeseed, dry skins, hides, butter, linen cloth, linen } \\
\text { yarn, bay yarn }\end{array}$ \\
\hline 1785.12 .13 & Hannah & Marks, S. & $\begin{array}{l}\text { Beef, linen yarn, bay yarn, linen cloth, butter, bacon, grease } \\
\text { butter, calves velves, feathers, pork hams }\end{array}$ \\
\hline
\end{tabular}

Source: Manchester Mercury 
was possible to match data from Eaton's "List" of exports and imports for the first quarter of 1785 .

Regardless of whether the port through which the goods cleared customs outwards was Dublin or Belfast, a large proportion of the consignments were despatched to Liverpool. Of the consignments loaded out from Dublin and arrived into Liverpool 17 were bacon, 12 were calf skins, 69 bay yarn, 46 beef, 19 butter, 12 calf skins, 16 feathers, four of flour, 15 hams, 12 hides, two oatmeal, eight of pork, 10 of tallow, eight tongues and two wheat as well as 138 consignments of linen cloth, and 138 of linen yarn. Amongst the consignments of merchants' goods from Dublin the Manchester Mercury recorded one consignment containing 40 bundles of corks, another consignment of 10 boxes of locks, one of 1,972 old gun barrels, and one lone consignment of wafers. The data for Belfast showed 19 vessels departed for Liverpool in 1785. Seven of the vessels list butter as their main cargo while beef is listed on three occasions, linen cloth on four and hides feature once.

There are six vessel arrivals in Liverpool from Dublin with goods listed in the Manchester Mercury for the same period of time as the exports from Dublin listed by Eaton; they are the Jennett $\mathcal{E}$ Jane, the Active, the Hannah, the Peggy, the Glory, and the Mary. All of these vessels made multiple voyages between Dublin and Liverpool throughout the year but in the period under review, only three of those arrivals appear as departures in the Freeman's Journal and New Lloyd's List: the Peggy, the Glory and the Mary.

The Peggy arrived in Liverpool on 8 February 1785. The Freeman's Journal listed the vessel as sailed for Liverpool with 'goods' and captained by Alex Cockran on 30 January 1785.109 The reports state it arrived in Liverpool with tallow, linen yarn, hams, beef, coney wool, furriers waste, quills, calf skins, tongues, pork, bacon and two feather beds ("belonging to said master"). ${ }^{110}$ The tallow may have been the

\footnotetext{
109 The Peggy is listed as a 70-ton brig, built in Chester in 1767 that underwent major repairs in 1780 and again in 1785. Cockran was the owner as well as the captain/master - not an uncommon occurrence in these smaller vessels. Lloyd's Register does not classify the vessel as a constant trader; the vessel travelled to more destinations than just the ports of Dublin and Liverpool.

${ }^{110}$ This is a slightly longer than normal voyaging time between Dublin and Liverpool. There are two possible explanations; the captain could have experienced some of the problems clearing Dublin
} 
240cwt cleared customs outwards by John Atkinson on 3 February. Pat McCormick cleared 147lbs of furrier's waste outwards through the Dublin customhouse on 29 January and this is possibly the three bales that John Thomas received from the Peggy. Roger Conolly cleared 145,000 quills outwards on 18 January and these are almost certainly the 9 packs of quills received by M. Dunn in Liverpool from the Peggy and listed in the Manchester Mercury's shipping news.

Joshua Pim and J. \& B. Wilson cleared consignments of bay yarn outwards through customs in Dublin on 15 January 1785. As the next available cargo vessel was the Hannah with S. Marks at the helm, it is feasible that the consignments uplifted in Liverpool by Samuel Green, M. \& T. Nicholson, Thomas Fleetwood and John Jackson from the vessel by 1 February, came from Pim or Wilson.

The definitions of the main categories applied to the Dublin goods apply equally well to the Belfast goods. These 26 vessels carried ten consignments of beef, 168 of butter, two consignments each of oats, barley, hides and pork and one of wheat. None of the consignments of linen yarn came from Belfast but 46 of the 309 consignments of linen cloth did leave from Belfast.

Alice Murray tallied the entries for exports of beef from Ireland in the custom house books for 1785 (Murray worked on her thesis in 1902 when the books were still available from the National Library $)^{111}$ and states a total 136,650 barrels of beef and 166 beef carcases left Ireland for all markets. Eaton's "List" itemized the exports of a total of 2,680 barrels and 3,153 tierces of beef despatched from Dublin in the first quarter of 1785; of these a total of 167 barrels and 258 tierces were destined for Liverpool. Murray's list includes 21,240cwt of tallow; Eaton lists a total of 1,415cwt exported of which 742cwt was destined for Liverpool. Murray's Table 1 of Appendix B continues with an entry of 58,445 barrels of pork exported from Ireland. In the first quarter, Eaton says a total of 1,510 barrels were exported from Dublin; 294 were destined for Liverpool. According to Murray 28,954 dozen calf skins left Ireland in 1785; Eaton has details for 508 dozen, of which 96 dozen were despatched

harbour completely or entering Liverpool, or he may have called at another port in Ireland after leaving Dublin, that is, 'step-voyaging.'

${ }^{111}$ Murray, A History of the Commercial Relations between England and Ireland. 
to Liverpool. 282,802cwt of butter was exported from Ireland; Eaton detailed the export of 4,581cwt left Dublin, and listed 138cwt for despatch to Liverpool.

The figures and analysis for 1770 from the Manchester Mercury shipping reports showed that there were 1,124 individual shipping movements ${ }^{112}$ recorded into the port of Liverpool, the largest proportion (34.2 percent) of which arrived from another English port. The next largest group (194 individual vessel movements, or 18.9 percent of the total vessel movements) arrived with an Irish port listed as their last port. These 194 individual vessels movements brought 1,609 individual consignments of goods to Liverpool for sale or re-export; 29 percent of those consignments left the port of Dublin, 25 percent originated in the port of Drogheda, and ten percent each from the ports of Belfast and Londonderry. Newry shipped nine percent of the total while Cork and other smaller ports despatched 18 percent of the total number of individual vessel movements. Dublin and Belfast ranked first and third respectively.

As the population of Liverpool increased rapidly in the mid-eighteenth century, so did the market for consumer and luxury goods. The calculation of the exact population suffers due to a lack of a census figure and the household surveys carried out in the late eighteenth century merely counted inhabited houses and used an average occupancy figure to calculate a total. Thus in 1773 the surveyor counted 5,928 inhabited houses and calculated 34,407 inhabitants. ${ }^{113}$ Brooke surmised from this figure that the population in 1775 was "rather more than 35,000 ". ${ }^{114}$ By 1785 the population reached approximately $77,000 .{ }^{115}$ It was not until 1801 that a formal count revealed the population as 83,708 but that "excluded Kirkdale, Everton, Lowhill, Edge-hill and Toxteth Park but included seamen". ${ }^{116}$

\footnotetext{
112 Brooke, Liverpool as it was; Brooke's figure of approximately 2,000 'vessels' paying dock duties in 1770 would indicate that the Manchester Mercury probably only reported the arrival of vessels discharging dutiable goods or those that required enumeration rather than total shipping which would also include passenger or mail vessels or other vessels or cargoes. For 1785, Brooke's figures show approximately 3,300 paid dock duties. As the figures were recorded for the year ended 24 June, the average of 1770+1771 figures, and 1785+1786 figures were used for the respective calendar years.

${ }^{113}$ Clemens quotes a figure of " 12,000 inhabitants in 1720 , and to two and half times that thirty years later" [equals 30,000 in 1750]; p.216.

${ }^{114}$ Brooke, Liverpool as it was, p.159.

${ }^{115}$ Hoh-cheung Mui and Lorna H. Mui, Shops and Shopkeeping in Eighteenth Century England, London, 1987, p.89.

${ }^{116}$ Brooke, Liverpool as it was, p.160.
} 
During the period 1770 to 1785 Liverpool was already deeply involved in transatlantic trade and had been for several decades. In common with Dublin, Liverpool was a major entry point for the return cargoes of exotic goods. The Manchester Mercury lists include the arrival of various woods such as mahogany, redwood and ebony, and spices such as Malaga pepper. As far as Liverpool's trade with Ireland is concerned, Whitworth stated that the main articles sent to England from Ireland emanated from the agrarian sector or the linen manufactures and this is borne out by the figures from the Manchester Mercury. Fifty percent of the consignments from Ireland were linen yarn (27 percent) or linen cloth (23 percent), while 15 percent of the goods were butter and 5 percent, tallow. ${ }^{117}$ In the reverse flow, Brooke noted that the main exports were "principally the productions of Manchester, Leeds, Sheffield, and Birmingham, with large quantities of earthenware from Staffordshire, and of salt from Cheshire."118

Liverpool was an important port to the exporters and importers of Dublin and Belfast. Many of the merchants, the facilitators of the trade, were expatriate Irish. Some were general merchants while others specialised in specific types of goods. As a group the Liverpool merchants of the last quarter of the eighteenth century have been described as 'mercantilist, materialist and empiricist.'119 In Chapter Four as much information as possible has been gathered about the main merchants in each of the communities, and then analysis is carried out on their role in the markets, their market share, and the market structure.

\footnotetext{
11751 issues (of the total of 52 printed) of the Manchester Mercury contained printed lists of shipping information for 1770. 1,124 vessel movements were listed, 521 (or 46.4\%) listed goods discharged at Liverpool in detail; 603 (or 53.6\%) have no goods listed. The reason for the lack of detail for this number of cargoes is not known. It would not be unreasonable, however, to conclude that the goods listed were subject to some form of duty or control by Customs and were therefore detailed for this purpose.

118 Brooke, Liverpool as it was, p.247.

119 S. G. Checkland, 'Economic Attitudes in Liverpool, 1793-1807,' Economic History Review, New Series, Vol. 5, no. 1, 1952, p.58.
} 


\section{Chapter Four: The Merchant Communities of Dublin, Belfast and Liverpool}
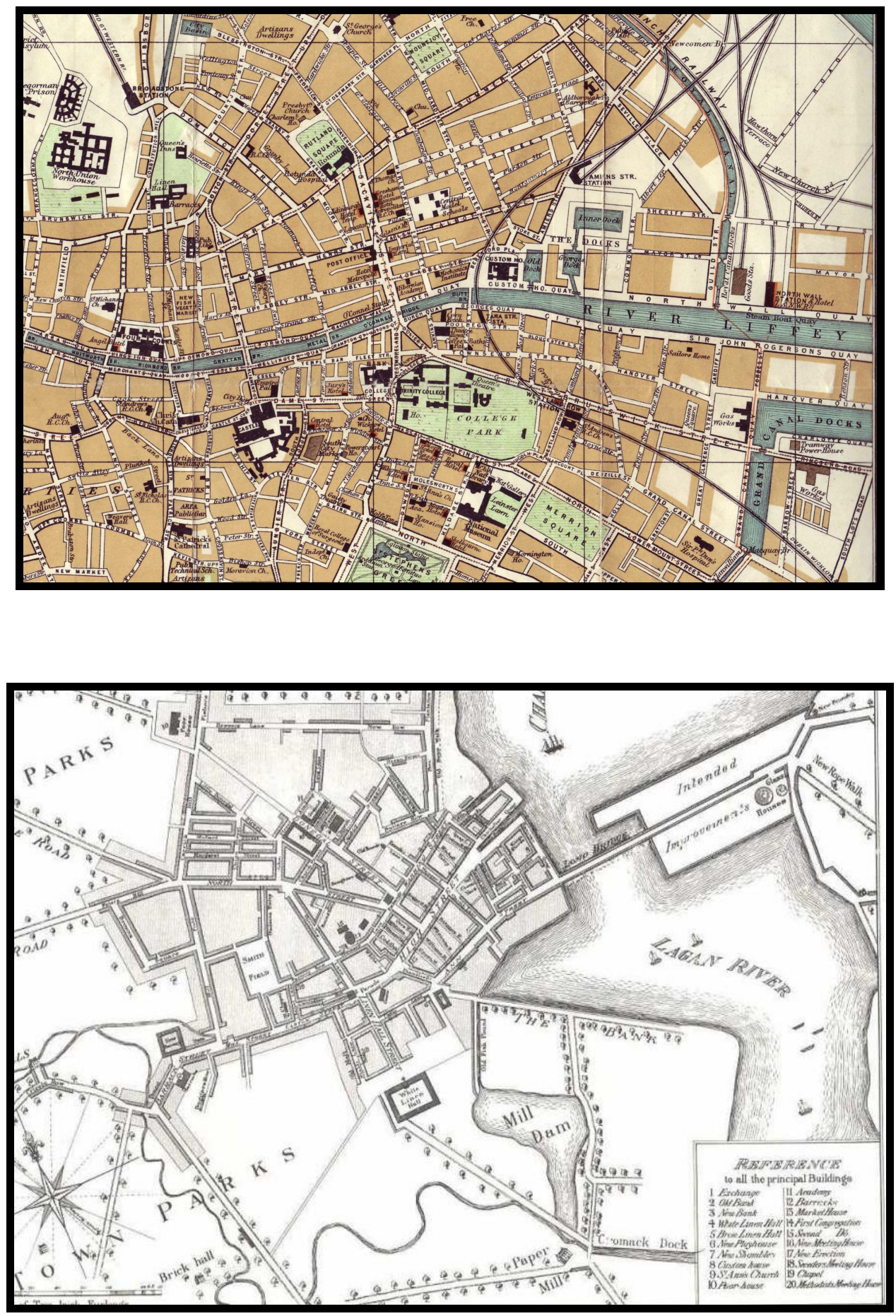
In this chapter the focus will shift to the facilitators of the mercantile and maritime interaction between Ireland and England - the merchant communities of Dublin and Belfast in Ireland, and Liverpool in England. The chapter is divided into five sections; the first gives a brief description of Ireland's banking system, and then each of the ensuing three sections is dedicated to one of the focus ports, that is, Dublin, Belfast, and Liverpool. Each section details who the key merchants were, the type of market they operated in, and their significance in the mercantile interaction between Ireland and England. The last section of the chapter discusses the market share and concentration ratios for butter and linen cloth, two of the key commodities imported into Liverpool from Ireland.

Dublin, by 1785, was one of the largest cities in Europe with a population of approximately 165,000 . It was described in 1776 as a city of contrasts, with "deplorable poverty and ostentatious extravagance" but with "some fine buildings and even finer plans for the future."121 Many of those earlier 'plans' had come to fruition and her marketplaces and quays teemed with activity. The spotlight falls on the merchant activity during the first quarter of 1785 and with evidence garnered from the trade directories, the Freeman's Journal newspaper, New Lloyd's List and from Richard Eaton's "List" of imports and exports, a more complete picture is revealed.

Belfast, although more sparsely populated than Dublin, ${ }^{122}$ and without the advantage of being the administrative and economic capital of the isle, nevertheless had a thriving merchant community, mostly dealing in the exportation of primary produce, and linen cloth and yarn. In the absence of trade directories, but with the use of the merchant advertisements placed in the Belfast News-Letter, some idea can be gained of merchant activity in the city at this time.

Although many historians have already examined, in some detail, the nineteenth-century merchant community of Liverpool, any who write on the latter decades of the eighteenth century emphasise the importance of the African and

${ }^{121}$ J. G. Simms, ‘Dublin in 1776', Dublin Historical Journal, Vol. 31-2, 1977-1980, pp.3, 12.

122 Estimates vary but in 1780 it was approximately 13,000. Arthur Young estimated the population as 15,000 in 1776 (p.166) but modern historians consider his figures to be about 20\% over-inflated. 
Caribbean traders. ${ }^{123}$ In contrast, the Liverpool link to the Irish provisioning trade received very little attention and so this narrative and analysis of the shipping news, with its lists of goods and consignee names, as recorded in the Manchester Mercury sheds new light on the activities of these merchants.

\section{- I -}

The role of the merchant evolved over many decades from that of the manufacturerartisan who negotiated sales for his wares within his own local market and in the markets of members of his social network who lived elsewhere. In many instances, the entrepreneurial talents of a particular manufacturer-artisan extended to selling the wares of other artisans as well. By the mid-eighteenth century this "strata of entrepreneurs...gradually...developed the more distant markets, more especially...those in London and overseas."124 In some early instances, these merchants also acted as financiers and the risk was managed through the London or European finance markets.

By the mid-eighteenth century, disposable income had increased markedly for the middle and upper classes in Ireland and England and this in turn led to an increased demand for 'luxury' goods. Although the lot of the lower classes had not improved, the increase in their numbers added to the increased demand for greater quantities and variety of staple goods. In response to this increased demand, the producers of Ireland increased output in order to have goods to exchange in overseas marketplaces. Ireland focussed on what she did well, that is, primary produce and linen manufacture. Vessels left Ireland for England or elsewhere, with butter, hides, pork or beef and linen, and returned with just what the market wanted - sugar, tea, tobacco, coffee, rum, brandy, dyestuffs, drugs, and other

\footnotetext{
${ }^{123}$ Little is known of the prominent eighteenth century merchants of Liverpool, as the spotlight has mostly been on those of the nineteenth century; the lives of a few, such as William Rathbone (his seventeenth century predecessors as well as his heirs), have been discussed at length, while others remain virtually unknown. They sometimes feature in volumes on other subjects but seldom have a dedicated biography written about them. This paucity of information on the eighteenth century merchant community extends also to the merchants of Dublin and Belfast. ${ }^{124}$ Stanley D. Chapman, 'British Marketing Enterprise: The Changing Roles of Merchants, Manufacturers, and Financiers, 1700-1860', Business History Review, Vol. 53, no. 2, Summer 1979, p.205.
} 
exotica or luxury goods. As a result per capita consumption rose steadily, especially in the latter half of the eighteenth century.

The manufacturers and producers of England, in many cases threatened by the sheer volume of Irish production, and lower costs of particular market sectors, such as linen, in turn increased the pressure to have their Irish rivals penalised. Lobbying of parliament to expand on the late-seventeenth century import restrictions and tariffs on Irish goods became something of a national pastime. In reality, the type of prohibitions and tariffs imposed were not restricted to just Irish produce but reflected the English unease at the quantities and prices of goods from any foreign markets. The English were also well aware that Ireland was not resource-rich, and some English lobbyists were not keen for the Irish to be heavily penalised because of Ireland's dependency on its nearest neighbours for coal and manufactured goods. Therefore, in what was clearly an inequitable situation each used their respective comparative advantages in particular market sectors for the betterment of their respective economies as a whole.

Merchants preferred the stable London commercial environment to the unstable local banking system of the earlier decades, in which a myriad of small scale, and some larger scale, financiers and private banks operated. ${ }^{125}$ Some of these financial institutions had relatively short life spans, and business transactions remained a complicated and high-risk activity. Various attempts to alleviate chronic shortages of coin by importing gold and silver coin from England only made matters worse. Irish copper coinage and English gold and silver coin circulated simultaneously, complicating matters further.

Agitation amongst the merchants and traders in Dublin and elsewhere for the establishment of a central bank for Ireland increased in the 1770s. Merchants viewed a centralised banking system as an important mechanism for the reduction of risk in trade and a way of streamlining the payments process. ${ }^{126}$ In 1780 ,

\footnotetext{
${ }^{125}$ According to C. MacCarthy Tenison (Honorary Fellow of the Institute of Bankers) the goldsmiths of the $17^{\text {th }}$ century were the earliest 'bankers' of Dublin - a role they fulfilled as many of their cohorts did elsewhere. He noted however that in the true sense of the word 'banker' it is the money-lender who also received money for safe-keeping who more closely resembles the banker.; C. MacCarthy Tenison, 'The Old Dublin Bankers', Journal of the Institute of Bankers, Vol. 2, 1900, pp.184-90.

${ }^{126}$ Often the introduction of a centralised banking system is considered to be an indicator of the maturation of an economy, but it is not clear from the contemporary literature whether the merchants
} 
merchants and bankers petitioned the Irish House of Commons, and they passed a resolution "for establishing a bank and incorporating certain persons by the name The Governor and Company of the Bank of Ireland."127 Progress was slow and the Bill only received the Royal Assent on 4 May $1782 .{ }^{128}$

The restrictions placed on the bank included a requirement that the Bank "'shall not owe, at any time, more than a sum equal to the said $£ 600,000^{\prime \prime \prime} 129$ and an inability to charge interest at any rate other than five per cent per annum. Subscription to the bank closed on 6 December 1782, fully subscribed. The Bank of Ireland opened in purpose-built premises in Mary's-abbey on 20 November 1784 following several months of accommodation in makeshift locations. Eventually however, this site proved wholly unsuitable and the bank moved to the former Parliament House on College Green, opposite Trinity College.

In 1786, Wilson's Dublin Directory, published the following:

\begin{tabular}{|ll|}
\hline Governor: & Right Hon. David La Touche; 45, Stephen's-green \\
Deputy-Governor: & Theophilus Thompson; 48, William street \\
Directors: & John Allen, Esq. 20, Batchelors-walk \\
& Patrick Bride, Esq. 40, Bride-street \\
& William Colvill, Esq. 6, Bachelors-walk \\
& Samuel Dick, Esq. 13, Linen-hall-street \\
& Jeremiah D'Olier, Esq. 87, Dame-street \\
& Travers Hartley, Esq. 84, Bride-street \\
& George Godfrey Hoffman, Esq. 9, Fleet-street \\
& James Hamilton, Esq. 15, up. Ormond-quay \\
& Alexander Jaffrey, Esq. 8, Ely-place \\
& John La Touche, Esq. 11, Ely-place \\
& George Palmer, Esq. 4, W. Park-street \\
& Amos Strettell, Esq. 9, Merion-square \\
& Jeremiah Vickers, Esq. 11, King's-Inns-quay \\
& Abraham Wilkinson, Esq. 4, W. Park-street \\
& Charles Ward, Esq. 12, Fownes's-street \\
& Secretary, Hill Wilson \\
Accomptant-general, Thomas Williams \\
Cashier, Townley Lawder \\
Chief book-keeper, John Herman Ohman \\
Clerk of the Discounts, George Draper \\
Notary, James Gibbons \\
Printer and Stationer, William Wilson. \\
Officers:
\end{tabular}

of Ireland felt their economy had matured or not. They clearly wanted to lower their risks and streamline their processes to gain efficiencies as well as profit.

127 F. G. Hall in George O'Brien (ed.), The Bank of Ireland, 1783-1946, Dublin, 1949, p.31.

${ }^{128}$ Initially created with a review date of 1 January 1794, the Lord Lieutenant could extend the life of the Bank by a notice in the Dublin Gazette.

${ }^{129}$ O'Brien, The Bank of Ireland, p.35. 
Many of the Directors of the Bank of Ireland were prominent merchants and citizens. According to Bank rules, at least five new Directors were appointed every year, chosen in the first week of April. However, since many of the names appear at regular intervals the control of the Bank remained with a small group of affluent members of the Dublin mercantile and commercial communities. ${ }^{130}$ With a stabilised banking and monetary environment in place, commercial transactions occurred at lower risk to the mercantile community and the expansion of markets and trade continued.

With the formation of the Bank of Ireland in 1783 the mercantile and commercial communities became more confident. They equated a centralised banking system with a more secure, less risky, commercial environment. Business transactions still occurred in Irish pounds and shillings, but final settlement usually took place in Sterling through financiers based in Dublin with links to the London bankers.

Such was the business environment that a merchant was free to trade in his or her own right, in a partnership with a specific lifetime, a long-term business partnership or as an "\& Co." entity. On both sides of the Irish Sea, the merchants used their business connections, capital and on occasion their own vessels to land goods at the appropriate wharf and arrange for their delivery or on-sale. There were merchants who clearly specialised either in markets or in commodities, while others operated as general merchant houses, handling goods on behalf of many exporters and importers. Merchants often formed temporary partnerships for the sole purpose of importing or exporting one or more cargoes of goods. These types of trading

\footnotetext{
${ }_{130}$ Wilson's Dublin Directory, 1786, p.12; Fourteen years later, according to John Watson Stewart's Almanac of 1800 (p.111) Jeremiah D'Olier occupied the position of Governor of the Bank of Ireland, with William Colville as Deputy-Governor. The list of Directors still included the names John Allen, Patrick Bride, Samuel Dick, George Godfrey Hoffman, George Palmer, Abraham Wilkinson and Charles Ward. During the intervening years, Thomas Williams rose to the position of Secretary but Townley Lawder was still the Cashier and George Draper, the Clerk of Discounts. James Gibbons remained as a Notary but Leland Crosthwaite, Joseph Goff, Joseph Hone, Alexander Kirkpatrick, George Lunell, William Rawlins, Arthur Stanley and Nathaniel Sneyd became Directors. The Rt. Hon. David La Touche (along with "J. \& P. La Touche") continued as "Bankers, 27 Castle-street", Theophilus Thompson, in the position of "Danish Consul in Ireland", John Allen (and Sons), William Colville, Samuel Dick, Travers Hartley (and Son), James Hamilton, George Palmer, Amos Strettell, Jeremiah Vickers, Abraham Wilkinson and Charles Ward as "Merchants", and Jeremiah D'Olier as "Goldsmith and Jeweller" while each held a directorship of the Bank.
} 
practices continued until the 'limited liability' entity became the norm in the early nineteenth century.

To spread the financial risk or to take advantage of a particular opportunity for capital gain, some merchants traded in multiple entities simultaneously. An example is that of the Liverpool merchant John Benson, who in 1770 imported butter from Belfast as "Benson \& Co.", from Coleraine, Londonderry, and Sligo as “John Benson \& Co.", and elephant's teeth from Africa as “Benson \& Postlethwaite." A further example is that of John Airey and James Suffern; each traded in their own right as well as in partnership as "Airey \& Suffern." ${ }^{131}$ In 1785, one such Liverpool merchant was John Dickson. He imported butter from Belfast, Dublin and Newry on his own account as "John Dickson," and then when he imported larger quantities of butter as "Dickson \& Pemberton."

\section{- II -}

\section{The Merchant Community of Dublin}

The commercial heart of Dublin, the mercantile capital of Ireland and home to the largest of the Irish commercial and mercantile communities in the late-eighteenth century, lay within easy walking distance of the wharves and the Customhouse. Wilson's Dublin Directory of 1770, includes 66 pages of 'merchants and traders' and lists approximately 2,600 trading entities - owner/operators, partnerships, and 'companies.' By the beginning of 1786 there were approximately 3,600 names listed. Most business premises were sited along George's Quay, Ormond Quay, Usher's Quay or Aston Quay, or they were located within close proximity of the Castle.

In his examination of the 'Irish merchants and ports', Thomas Truxes found that in the early eighteenth century the majority of the Dublin merchants traded with the expatriate communities of the Caribbean. ${ }^{132}$ His case studies include those of the partnership Marsden \& Benson who imported sugar from the West Indies and traded Irish linens to the British North American mainland colonies for

\footnotetext{
${ }^{131}$ Examples abstracted from the shipping reports of the Manchester Mercury.

132 Truxes, Irish-American Trade; with an end date of 1783 it is not possible to utilise his work for the 1785 analysis.
} 
flaxseed. The Quaker community of Dublin, including the partnerships of 'James Lecky \& Co.' and 'Robinson \& Sandwith', traded most frequently with their kith and kin in Pennsylvania. Truxes, in following the business affairs of the two trading entities, found links to the Philadelphian firm of Coates \& Reynell, and to individuals such as Isaac Norris, Israel Pemberton and Henry Drinker. ${ }^{133}$

Eighteenth century 'Irish-American' trade is, however, a very small percentage of the trade leaving Dublin. The figures gathered from the Manchester Mercury, Freeman's Journal, Dublin and Lloyd's New Lloyd's List for 1770 clearly show that more than 60 percent of the identified shipping movements out of the port of Dublin arrived at an English port. Only about ten percent (in total) went to an American colonial port or a destination in the Caribbean and a little over 20 percent left Dublin for a European port, while just less than five percent was despatched to a Scottish port. ${ }^{134}$ Fifteen years later the data indicate a slight rise in the percentage of movement out of the port to England and Europe and a fall in the number of vessels destined for the Caribbean and American colonies - from 9.4 percent (35 vessel movements) in 1770 to 8.1 percent (19 vessel movements) in 1785.

Richard Eaton's "List" provides us with a great deal of detail as to who was trading in Dublin in the first quarter of 1785 and in what commodities they dealt. ${ }^{135}$ Of the 141 trading entities listed by Richard Eaton as exporters of the 462 consignments that arrived in Liverpool, the vast majority exported fewer than nine consignments each. Only eight exporters each sent ten or more consignments - John Atkinson (13), Montgomery Crothers (10), Richard \& Michael Dodd (19), Sam Laurence (10), Thomas Oldham (14), Sam Stephens (14), Henry Westray (10) and Joshua \& Benjamin Wilson (11). The following is a discussion of the activities of these eight exporters.

\footnotetext{
133 Truxes, Irish-American Trade, pp.75-6.

${ }^{134}$ Of the 373 named vessels that left Dublin, identified from the Freeman's Journal, Dublin (for the 1770 calendar year) and Lloyd's Lists (between 1 January and 23 October 1770 - the other lists are missing), 17 went to 'American colonies', 18 to the Caribbean, 229 to England, 76 to Europe, 12 to another port in Ireland, 17 to Scotland and 4 had no destination listed. As well as the named vessels there are entries for numerous 'vessels', 'coaster's', and 'colliers' that cannot be identified. ${ }^{135}$ Appendix I of this thesis contains the names of all the merchants mentioned in Eaton's "List" and their details, where available, from the Dublin Directory of 1786.
} 
The Dublin Directory of 1786 listed John Atkinson as "merchant, 25, Fleetstreet." A symbol " $\dagger$ " printed next to his name denoted his business status as "wholesale Merchants free of the 6 and 10 per cent in the Custom-house, Dublin."136 According to Eaton's "List" Atkinson managed the export of 377 bacon hams, a total 579 salt Hides, 500lbs of indigo, 60 dozen calf skins, and $723 \mathrm{cwt} / 4 \mathrm{qr} / 50 \mathrm{lb}$ of tallow offshore from Dublin in the first quarter of 1785 alone. The only commodity imported by Atkinson from Liverpool was 'muscovado' sugar. He took delivery of $1,356 \mathrm{cwt} / 2 \mathrm{qr} / 39 \mathrm{lbs}$ from that port of lading, but also imported other $1,041 \mathrm{cwt} / 0 \mathrm{qr} / 7$ lbs from London and 444cwt/3qr/14lbs from Lancaster. He also imported a relatively small quantity of rum (10 puncheons from Greenock, Scotland) and tobacco $21,034 \mathrm{lbs}$ directly from Virginia and 22,728lbs from London. Atkinson was the largest importer of raw muscovado sugar ${ }^{137}$ and the fourth largest importer of tobacco.

Montgomery Crothers sent ten consignments to various destinations in the same timeframe. These included: $19 \mathrm{cwt} / 3 \mathrm{qr} / 23 \mathrm{lbs}$ of bacon hams, 280 tierces of beef, 400,000 yards of linen cloth ("not for bounty"), 12cwt/3qr/15lbs of linen yarn, 22 dozen tongues and 10 barrels of pork. He does not appear on the list of importers. It is therefore difficult to define Crothers as a prominent merchant when all the criteria are considered - he deserves recognition here primarily for the quantity of linen exported.

The Dodd brothers (Richard and Michael), "Dry-coopers \& Merchants" of “5, Bow-1[ittle]", despatched 749 bacon hams, 402 tierces and 6 barrels of beef, 220 salt Hides, 200 dozen calf skins, 4,000 ox horns, 57 dozen tongues, 10cwt/1qr of butter, and $60 \mathrm{cwt} / 2 \mathrm{qr}$ tallow. They also exported 1,201 barrels of oats, and $3 \mathrm{cwt} / 1 \mathrm{qr} / 14 \mathrm{lbs}$ of linen yarn in 19 different consignments. Clearly, the Dodd brothers focussed mainly on primary produce at this time, and as their names only appear once in the imports list ${ }^{138}$ they are obviously primarily exporters, making their living on the commissions or percentages of outbound goods handled.

\footnotetext{
${ }^{136}$ Explanation of the symbol comes from the Dublin Directory, p.13.

137 Atkinson 2,842cwt/6qr/50lb from all sources; Alley \& Darby 1,689cwt/8qr/104lb; Edward Byrne 1,535cwt/9qr/116lb; John Cowan 1,344cwt/6qr/57lb. Figures abstracted from Eaton's "List."

138 They imported 35cwt of 'cudbear' from Greenock in Scotland in March 1785. Cudbear is a type of lichen which produces a purple dye.
} 
Samuel Lawrence, also a dry-cooper, operated from "123, Abbey-street" and specialised in pork, beef and bacon product, sending 30 bacon flitches and 24 bacon hams to market, as well as 59 barrels of pork and 27 barrels/119 tierces of beef. Although the frequency of Lawrence's exports is at the lower end of the numbers of other merchants' consignments, the volumes he dealt highlight his importance to the market. The 27 barrels of beef weighed 6,048lbs and the 69 barrels of pork 15,456lbs. ${ }^{139}$ His name does not appear on the list of importers, and like Richard and Michael Dodd, he made his living from handling outbound goods.

Thomas Ouldham was listed as "Merchant, 94, N.[orth] King-street" and from Eaton's "List" it would seem he also specialised in primary products, exporting more than 300 salt hides, 29 dozen calf skins and more than 400 dozen kips \& runners, and $44 \mathrm{cwt}$ of kelp out of the port of Dublin in the first quarter of 1785. Early in January, he imported 120 barrels of bark from Liverpool but no other mention is made of him in Eaton's list of importers.

Another produce dealer was wholesale merchant Samuel Stephens, “Grocer, 30, Bishop-street." He sent 239 bacon flitches to London, 4 to Bristol and 36 to Liverpool. All of the $82 \mathrm{cwt} / 2 \mathrm{qr}$ and 500 loose bacon hams went to Liverpool, the beef all went to Irvine in Scotland, the vast majority of the butter went to London (along with the 30 barrels of oats). Only $69 \mathrm{cwt} / 3 \mathrm{qr}$ of butter was sent to Liverpool. Sam Stephens imported ten hogsheads of beer from London in March of 1785 and that is the only time his name is mentioned in the imports list.

Henry Westray operated his tanning business from “57, James's-street," and the 2,093 salt hides he sent to clients offshore make him an important merchant in this market sector. No other merchant handled transactions for as many salt Hides as Henry Westray did at this time. The $12 \mathrm{cwt}$ of butter may have been a one-off consignment to maintain cash flow or handled by Westray for some other reason. Westray's name does not appear in the list of importers.

The Wilson brothers, Joshua and Benjamin, handled a large sector of the linen and yarn exports in the first quarter of 1785. A total of 2,920 great stones of bay yarn and a total of $357 \mathrm{cwt} / 10 \mathrm{qr} / 26 \mathrm{lbs}$ of linen yarn were despatched in the name of

139 This is equivalent to 2.7 tonnes of beef and 7 tonnes of pork. 
"Joshua \& Ben. Wilson." They imported over 20,000lbs of tobacco and a small consignment of common pitch directly from Philadelphia.

None of the eight exporters appear to specialise in any one commodity. All are general merchants but some of the exporters facilitate quite large quantities of the commodities. The majority of the eight were also importers. Of the other merchants listed by Eaton, Joshua Pim, "Merchant, 15, Usher's-island" despatched 1,506 great stones of bay yarn to Liverpool between January and March of 1785 and imported 1,100lbs of cotton wool from London on 7 January. Joshua Pim was a leading citizen of Dublin and belonged to the Ouzel Galley Society. He also subscribed to the formation of the Dublin Chamber of Commerce in 1783. ${ }^{140}$ The only other merchants who dealt in bay yarn were Abraham \& Peter Wilkinson, and John McLoghlin. The Wilkinson brothers exported 900 great stones and John McLoghlin 405 great stones of the total of 5,731 great stones that left Dublin in the three months ended 25 March 1785.

In some instances the detailed information contained in Eaton's "List" for exports matched information of arrivals and details of cargo consignees in the Manchester Mercury. ${ }^{141}$ Merchants or brokers in Dublin consolidated consignments from multiple exporters for 'shipments' of commodities to re-sellers or on a few occasions one exporters' goods matched one consignment received in Liverpool.

The following are examples where one export consignment listed by Eaton matched one consignment arrived in Liverpool. In the first example, Sam Laurence exported '103 tierces beef' to Liverpool on 15 January 1785. Those 103 tierces arrived in Liverpool, as reported in the 1 February issue of the Manchester Mercury, on board the Hannah with S. Marks at the helm. ${ }^{142}$ Of those 103 tierces, 79 were consigned to

\footnotetext{
${ }^{140}$ From an article written by Mr George Eaton which appeared in the Christmas 1991 issue of the magazine of the Dublin Chamber of Commerce, of Ireland.

${ }^{141}$ Sadly, without details of the exports from Liverpool it is not possible to carry out this same exercise of data matching for the goods listed by Eaton as imports into Dublin.

${ }^{142}$ It is unclear when the Hannah actually sailed from Dublin, as there is a gap in the port news "sailed" listings of the Freeman's Journal from 18 January to 27 January 1785. As the coastal vessels were often referred to by the number of vessels sailing rather than listing their names, it will not be possible to use this source to corroborate the information. The Lloyd's List reports of vessel leaving and arriving at "Irish \& Foreign Ports" do not include any reference to the Hannah, nevertheless I believe the conclusion drawn by this author is the correct one.
} 
H. Delamaine, ten to Hancock \& West, and 14 to J. Thomas. Peter Howard ${ }^{143}$ exported '35 tierces beef' to Liverpool on 24 January and the Manchester Mercury reported on 8 February that 35 tierces of beef 'for John Thomas'144 arrived from Dublin as part of the cargo on board the Peggy with A. Corkron as master.

Joshua \& Benjamin Wilson, ${ }^{145}$ and Joshua Pim each exported great stones of bay yarn on 15 January 1785; in fact, the two exporters sent 651 great stones to Liverpool on board the Hannah. Samuel Green, M. \& T. Nicholson, ${ }^{146}$ Henry Wharton, ${ }^{147}$ Thomas Fleetwood, ${ }^{148}$ and John Jackson ${ }^{149}$ all received consignments of bay yarn from that vessel - between them, 75 packs. Missing from the picture, however, is the equivalency of how many 'great stones' of yarn can be packed into a "pack."150

Another entry on Eaton's "List" shows John Ellerton"151 exported three hundredweight of feathers on 17 January 1785. F. Neil of Liverpool imported ' 7 bags feathers' on the Active and Urmson \& Gregson and "said master" are listed as the consignees of two packs each of feathers on board the Hannah. While ' $3 \mathrm{cwt}^{\text {' of }}$ feathers seems a lot of feathers, we do not have any dimensions or weights for the "bag" or "pack" so it is entirely possible that all of Ellerton's feathers were purchased by these consignees.

Thomas Oldham ${ }^{152}$ sent “5 dozen skins - kips \& runners" from Dublin to Liverpool on 27 January 1785 on board the Hannah. George Goring imported 60 ox hides into Liverpool - these appeared in the list of arrivals in the Manchester Mercury of 1 February 1785.

\footnotetext{
143 Peter Howard, Dry-cooper, 6 Smock-alley; Dublin Directory, p.56.

144 This is possibly the "John Thomas, Merchant, 115 Park lane" listed in Gore's Liverpool Directory, or alphabetical list of the merchants, tradesmen, and principal inhabitants of the town of Liverpool; with the numbers as they are (or ought to be) affixed to their houses..., Liverpool, 1790, p.140.

145 Joshua and Benjamin Wilson, Merchants, 48 Golden-lane; Dublin Directory, p.104.

${ }^{146}$ An entry for "Thomas and Matthew Nicholson, Merchants, Dale street" appeared in William Bailey's Western and Midland Directory, or merchant's and tradesman's useful companion for the year 1783, [hereinafter Bailey's Directory], Birmingham, 1783, p.258.

${ }^{147}$ Henry Wharton and Son, Brokers, Park lane; Bailey's Directory, p.262.

148 Thomas Fleetwood, Broker, High street; ibid, p.253.

${ }^{149}$ John Jackson, Broker, Launcelot's Hey; ibid, p.356.

150 The definition of a 'great stone' has so far eluded the author - it would seem from its name that it weighs more than a normal stone of $14 \mathrm{lb}$. Zupko says a pack of yarn is 4cwt or $480 \mathrm{lb}$.

${ }^{151}$ John Ellerton, Grocer, 5 George's-street; Dublin Directory, p.41.

152 Thomas Ouldham, Merchant, 94 N. King-street; ibid, p.81.
} 
Roger Conolly ${ }^{153}$ exported 145,000 quills from Dublin to Liverpool on board the Peggy, captained by A. Corkron. According to the shipping news in the Freeman's Journal, the Peggy left Dublin for Liverpool ("Alex. Cockran”, master) with "goods" on 30 January $1785 .{ }^{154}$ Reports of the vessel's arrival and cargo appeared in the 8 February issue of the Manchester Mercury and included a reference to "9 packs of quills, M. Dunn." Without knowing how many quills fit into a 'pack' and in the absence of any other references to quill imports, this author has concluded that McCormick packed 145,000 quills into the nine packs received by M. Dunn. ${ }^{155}$

The Active and the Hannah arrived from Dublin and the list of the cargo discharged at Liverpool appeared in the issue of the Manchester Mercury dated 1 February 1785. According to Eaton's list, merchants Joshua and Benjamin Wilson despatched $14 \mathrm{cwt}$ of hams from Dublin on 22 January 1785. The manifests for the Active and Hannah showed 6 hhds ${ }^{156}$ of hams "to order" for the former vessel, and one hogshead, 13 loose hams "to order", and one hogshead hams for "said master" on the latter. It is not known what each of the hogsheads weighed as the hams would have been of differing weights, as is the number of hams in each hogshead. This author is therefore unable to ascertain whether all of the Wilson hams were unloaded in Liverpool or whether $14 \mathrm{cwt}$ of hams could fit into eight hogsheads.

John Thomas received three bales of furriers waste from Dublin according to the arrivals list for the Peggy dated 8 February 1785. Pat McCormick ${ }^{157}$ despatched 147 lbs of "furr" to Liverpool on 29 January and as no one else in Liverpool purchased this commodity at this time, it appears the exporter and the importer match.

\footnotetext{
153 There is no entry in the Dublin Directory of 1786 for a Roger Conolly. A check of the 1770 directory failed to find anyone by that name entered into the list of merchants and traders gathered by Wilson. ${ }^{154}$ Freeman's Journal of Dublin, issue 2 February 1785.

155 There are no entries for "M. Dunn" in the Bailey's 1783 Liverpool Directory but in 1790 Gore's Liverpool Directory (published 1790) lists "Morgan Dunn, Dealer in Quills, 22 Gerard street, Byrom street." Gore's Liverpool Directory, 1790, p.41.

$156 \mathrm{hhd}=$ hogshead; The hogshead is usually associated with quantities of liquid, that is, 1 hhd holds 63 gallons, but often they were used as a measure of solid material as well, in which case the weight of a hogshead would vary according to what was being transported in them.

${ }_{157}$ One entry on the list shows Patrick McCormick, Skinner, 6 Watling-street but also lists a P. McCormick as a "Skinner \& Feather merchant", 63 Dirty-lane - either of whom could have exported the goods; Dublin Directory, p.68.
} 
The preceding examples have highlighted how valuable the detailed information contained in Eaton's "List" and the shipping news of the Manchester Mercury can be. Along with the trade directories, it has been possible to reconstruct details of the mercantile and maritime interaction between Dublin and Liverpool, and other ports in Ireland. In several cases, direct links between the exporter in Dublin and the consignee in Liverpool were uncovered; in others the trading patterns of the leading exporters and importers were revealed. Further analysis of these patterns is discussed in section five of this chapter.

Eaton's "List" names 530 individual trading entities as importers of goods into Dublin for the first three months of 1785 . There were 2,178 consignments and thus almost all of them imported fewer than nine consignments each. Several, however, import ten or more consignments and a small number import more than twenty. Ranking the major importers, Edward Byrne imported 46, Alley \& Darby 27, Jacob Moran 26, Patrick \& Co. 24, Carrothers \& Wilson, 23, John Frederick Kelly 23, Philip Molloy 23, and Westlake \& Stanley 21. Frequency of consignments is one measure of a merchant's importance, but specialisation and market share can reveal other rankings. Whitworth listed the main exports of England to Ireland as: "Iron, Hops, Seeds, Pepper, Tea, Pearl-ashes, Tobacco, Indico, Spices, Colours, Allum, Coals, Cotton, Beaver, Wool, Logwood, Silk, Mohair, Yarn, calicoes, Earthen-ware, Furniture mats, Glass, Pewter, Beer, Grocery, Sugars in all their different states of refinement...."158 A number of these items are, of course, not locally produced but merely re-exports of imports into England from offshore markets. To analyse Dublin merchants' specialisation and market share, we will consider only Seeds, Tobacco, Earthen-ware, Beer, and Sugars.

Several types of seeds arrived in Dublin, mostly from London, including canary, caraway, clover, garden seed, peas and beans, trefoil seed, hemp seed, onion seed and most importantly flaxseed. All 57cwt of the canary seed that arrived in Dublin came from London. The top four importers were James Joseph Dodd, who imported 15cwt, John Phelan (9cwt), and Edward Hay and Benjamin Simpson, who

158 Whitworth, State of the Trade, p.xxvii-xxviii. 
each imported 6cwt. Of the five other importations of seed from London made by James Joseph Dodd, the largest was for 1cwt of onion seed. ${ }^{159}$ He also imported 30 bushels of hemp seed. Phelan made ten other separate importations of various seed types and appears in the Dublin Directory as "Seedman, 10, Christ-church-lane"; Phelan clearly specialised in the importation of seed for his business, as he does not appear as an exporter. Edward Hay ${ }^{160}$ was also a specialist seedsman although his name did not appear in the Dublin Directory — instead Ann Hay appears as "Seed merchant, 4, Church-street" - nor is his name in Eaton's list of exporters. Benjamin Simpson, whose premises were located at "3, Cork-hill", followed a similar buying pattern to that of Edward Hay, specialising in seeds and not exporting any goods.

A total of $430,204 \mathrm{lbs}$ of tobacco arrived in Dublin, either directly from the American colonies or via the markets of Scotland, London or Liverpool. The largest importers were the firm Lecky \& Wilson who imported 95,439lbs, Val. \& Malachy O'Connor with consignments totalling 91,076lbs, John Smith 71,490lbs and John Atkinson 53,024lbs. All but 11,069lbs (which came via Greenock in Scotland) of Lecky \& Wilson's tobacco imports came directly from the Colonies; Philadelphia, Baltimore and 'Virginia' each appears in the list as the port of lading. Lecky \& Wilson also imported a small quantity of flaxseed and hemp seed and 70 barrels of apples. The O'Connors not only imported a large quantity of tobacco, but also imported a variety of other goods into Dublin on behalf of its clients; from figs to dressed deerskins, from planks of mahogany to sarsparella, the merchants from 'Bachelors-walk' brought it to the Dublin marketplace. Oporto, Leghorn, Jamaica and Philadelphia are all listed as ports of lading. The only commodity the O'Connors exported is butter - and only a relatively small quantity at that. According to Eaton, John Smith only imported tobacco. Only one of his shipments came directly from Virginia - the rest shipped via Liverpool, Greenock and Port Glasgow.

All the earthenware imported into Dublin, according to Eaton's "List," came from Liverpool. The earthenware would have come from the large potteries in

\footnotetext{
159 This is incorrect - Pat. Simpson imported 2cwt/1qr/22lb from London.

160 Edward Hay imported 100 bushels of hemp seed.
} 
Lancashire and Staffordshire; their nearest port was Liverpool. ${ }^{161}$ The largest importer was Thomas Wolfe who imported nine consignments totalling '116 crates, 122 half-crates, 29 dozen'. Wolfe specialised in "China, Glass and Delft[ware]," according to the Dublin Directory, and operated from premises at 9, Temple-bar. Only James Jackson (who is not listed in the Directory) imported anywhere near the same quantity of earthenware - but his five consignments only totalled ' 49 crates, 39 half-crates, 14 dozen' items. Most other importers only brought in one or two crates.

Ironically, Ireland had a thriving brewing business, but still imported quite large quantities of beer from England - especially from London. Merchants in Dublin imported 4,148hhds of beer into Dublin in the first three months of 1785 . This equates to 261,324 gallons and approximately 1.5 gallons per person if the population of Dublin in 1785 is approximately 165,000. ${ }^{162}$ Leonard \& O'Reilly, "Porter-merchants, 23, Francis-street" imported 1,100 gallons, all of which came from London. This quantity made them the largest importer of beer at this time. Thomas Haswell ${ }^{163}$ imported 975 gallons (all of it from London) and Carrothers \& Wilson $^{164} 850$ gallons - again all sourced from London.

Dubliners certainly imported large amounts of sugar in its various 'forms of refinement'. The end-user is most likely to have been the brewing and/or the distilling industry. In the period to 25 March, 1785 26,566cwt/2qr/10lb of raw muscovado sugar arrived from London, Liverpool, Port Glasgow or Greenock, with a very small quantity directly from Jamaica as well as $1,328 \mathrm{cwt} / 3 \mathrm{qr} / 17 \mathrm{lb}$ of refined sugar loaves from London, Bristol or Liverpool. Doyle \& Roe ${ }^{165}$ imported the largest quantity of the refined sugar loaves while John Atkinson was the largest importer of the muscovado sugar. This is almost $0.2 \mathrm{cwt}$ per person for every person in Dublin,

\footnotetext{
161 The manufacture of pottery earthenware in Liverpool dates back to 1700. Liverpool's earthenware and porcelain were exported around the world; Peter Hyland, The Herculaneum Pottery: Liverpool's Forgotten Glory, Liverpool, 2005.

162 Peter Somerville-Large, Dublin, London, 1979, p.182; figure 150,000 in 1776 increased by this author by ten percent to take into consideration natural and migrant increases in the ensuing nine years. ${ }^{163}$ Listed as a Porter-merchant, with premises at '33, Temple-bar'.

164 This trading entity does not appear in the Dublin Directory for 1786; it may have ceased trading in late 1785. It does not appear in the Eaton list of exporters.

165 Merchants of '20, Temple-bar' according to Dublin Directory, p.39.
} 
but bearing in mind that this is for only one quarter of the year a yearly figure of close to $0.8 \mathrm{cwt}$ is more likely.

In Dublin no one firm achieved sufficient market power to exclude competitors in any commodity sector. What has emerged from this analysis, however, is a picture whereby many merchants specialised in a small sector of the whole market and dominated that particular sector while others merely made a living from what they imported. Those listed as wholesale merchants in the Dublin Directory often dominate the Eaton lists but just as many, if not more, names of small-scale specialists appear on the list.

Eaton's "List", the list of merchants and traders reproduced in Wilson's Dublin Directory for 1786, and the newspaper reports of the shipping movements for Liverpool recorded in the Manchester Mercury have assisted in this examination of the merchants of Dublin and their activities for the first quarter of 1785. A longer series of data would allow for the identification of patterns and seasonal trends. Certainly, the information available about the arrivals of goods from Dublin into the port of Liverpool helps us to see how much arrived there and who received the goods.

\section{- III -}

\section{The Merchant Community of Belfast}

Thomas Truxes characterised the early eighteenth century merchants of Belfast as the exporters of the "largest share of the beef, pork, and butter sent from the northern towns, mostly directed to the planters of the West Indies."166 However, as with the case of Dublin, Truxes' narrow focus on the Irish-American trade distorts the significance of that trade in the context of Belfast's overall trade figures. Analysis of the identified shipping movements out of the port of Belfast in 1770 shows that 38.1 percent of the vessels left destined for an English port, 31.5 percent left for Scotland and 17.1 percent for the Caribbean. The data for 1785 indicate that only five

\footnotetext{
166 Truxes, Irish-American Trade, p.331 cites "PRO Customs 15; N. E. Gamble, "Business Community and Trade of Belfast", PhD thesis, Trinity College, Dublin, 1978, pp.13, 96, 301-302"; for a list of Belfast merchants in the butter trade, see Belfast News-Letter, 20 January 1764"' - these sources not sighted by this author.
} 
percent of the vessels were destined for the Caribbean; 7.3 percent left for the American colonies, 18.2 percent for Europe, 22.6 percent for Scotland and 27 percent of vessels departed from Belfast for an English port. The figures show clearly that the percentage of trade to the Caribbean was higher in 1770 than in 1785 while vessel movements between Ireland and England increased significantly. ${ }^{167}$

In the absence of Belfast trade directories, customs lists or business records one must rely on the Belfast News-Letter to piece together Belfast's mercantile sector. ${ }^{168}$ The issue covering the period 'Tuesday March 1 to Friday March 4, 1785' contained 26 items related to trade and six shipping advice notices; the 'Friday June 3 to Tuesday June 7, 1785' issue included 12 items related to trade and seven shipping advice notices. In the first of the issues selected, William King of Belfast announced he "has just arrived per the [vessel] Linen-Hall, Capt. Dickson, from London, his general Assortment of GARDEN SEEDS \&c, \&c." Robert Getty and William Emerson, and the partnership of Davison and Miniss (all of Belfast), along with William Dillon of Lisburn, also advertised seeds arrived as cargo on the LinenHall. ${ }^{169}$ However, the vessel did not only carry seeds; in the same issue, Robert Getty also announced the arrival of "New TEAS, consisting of Boheas, Congous, Greens, and Hysons" and stated, "He will as usual sell them per the Chest at Dublin prices."170

\footnotetext{
${ }^{167}$ The figures do not include those voyages made by the numerous 'colliers', 'coasters' and 'vessels' listed in the sources. These are known to have come from England but are not identified by name just listed as "six colliers" or "five coasters" or "two vessels".

168 Lloyd's Lists for arrivals at the port of Belfast for 1786, added a further 117 vessel movements to the data gathered from the Belfast News-Letter but unfortunately New Lloyd's List contains no information at all about what goods were carried, or who the consignees were.

${ }^{169}$ Lloyd's Register of 1786 (covering vessels surveyed up to and including the first few months of 1786) lists the Linden-Hall as a Brig, built in Liverpool in 1783 and owned by 'Stevenson \& Co'. Its burthen weight was 150 tons and sailed with a draught of 13 feet. When surveyed its condition was listed as 'A1'. LR1786, L124. "H. Dickson" is listed as the Captain in 1786 and again in 1790 (LR1790, L135). The Belfast News-Letter reported the vessel arrived 13 February 1785 although the New Lloyd's List published 25 February says it arrived on the $15^{\text {th }}$.

170 Belfast Neww-Letter, 4 March 1785, pp.1, 3, 4; with nearly ten times the population of Belfast, Dublin market prices for tea would almost certainly have been lower than Belfast retail prices. By keeping the selling price to that of Dublin, Getty was no doubt attempting to attract customers and would have been working on a low profit margin.
} 
The vessel Belfast Packet arrived on the same day (according to the Belfast News-Letter) from Rotterdam with Captain English at the helm. ${ }^{111}$ Robert Getty took delivery of a shipment of red clover seed along with "French Barley, Anetto, Madder, White Lead, first, second, and third Powder Blue, and a considerable quantity of Spices, which latter will be sold to wholesale dealers as low as they can be imported from London." McKedy and Stevenson imported "a very large and extensive assortment of GARDEN, TREE and FLOWER SEEDS, Garden peas and Beans...Teas and fresh Seltzer Water." Thomas Wright of Monaghan, some seventy miles from Belfast, also advertised garden seeds from Rotterdam, evidently transhipped to him after their arrival on the Belfast Packet.

Other merchants with advertisements in this March issue of the paper include: Robert Bradshaw (of Belfast), who "has just imported a Quantity of his usual Kind of POWDER BLUE"; William and John Brown, who "have just landed a Parcel of PORTER;" and John and James Holmes, a trading partnership based in Belfast, listed as selling Alicante Barilla, Dantzig Ashes, Oil Vitriol and Iron Hoops but also "Swedish and Russia Iron" and "German and Blister Steel."

Merchants in other centres, clearing their goods through the port of Belfast, also advertised in the Belfast News-Letter. Thomas Waring of Newry, for example, advertised "Dantzig Weed Ash, London Oil of Vitriol, Smalts, Dutch and American flaxseed and French Cyder". In March 1785 William McConchy of Antrim "has now for Sale, in fine order, a Quantity of strong well-flavoured Antigua and Jamaica Rum, Cogniac[sic] Brandy, and Gineva,[sic] Claret of the Vintage 1780, Red and White port." That same day Richard Penton, a merchant from Armagh "is now landing from the Draper, Capt. Hughes, a large Assortment of Garden Seeds, Flower Seeds of all Kinds."

Ships' agents advertised the proposed departure of vessels one to four weeks in advance, as merchants wanted their captains to depart with a full hold. John Hyndman of Bridge-street acted as agent for the owners of "the Good Brigantine SALLY", destined for Baltimore in Maryland and Richmond in Virginia. ${ }^{172}$ In

\footnotetext{
${ }^{171}$ New Lloyd's List published 25 February 1785 noted the arrival also.

172 There is no note in the Belfast News-Letter of the Sally's arrival from Liverpool but an entry shows several unnamed "coasters" and "vessels" arrived within weeks of that notice. New Lloyd's List shows
} 
advertisements dated 10 February 1785 and March 4, 1785 issue, Hyndman announced the vessel's arrival "in this harbour from Liverpool in a few days" and stated it would "positively sail from hence the $10^{\text {th }}$ of March." It continued, "a few Cabbin [sic] passengers can be comfortably accommodated." The advertisements often included 'glowing' testimonies of the skills of the master or the captain, in an attempt, perhaps, to attract passengers away from competing vessels and give confidence to insurers. Such an example is the advertisement for the Paca, with Robert Caulfield as Master, and scheduled to depart ${ }^{173}$ (on only her second voyage) for 'Baltimore in Maryland' at the same time as the Sally. The twelve individuals named at the end of the advertisement "think it a point of our duty to return thanks to Capt. Robert Caulfield of the ship Paca, for his kind and generous treatment to us during our passed from Baltimore to Belfast..." The advertisement described Caulfield as "a man of well known goodness and humanity."

The Friendship arrived in Belfast from Philadelphia with a cargo of flaxseed on 2 February 1785. ${ }^{174}$ The merchant William Burgess acted as ship's agent for the outbound voyage and advised would-be passengers and exporters that the master John McCadam would sail for Newcastle (Pennsylvania) and Philadelphia on 10 April. The advertisement stated, "the Friendship is a New Ship, built purposely for carrying passengers, and is allowed by all judges to be one of the finest ships in the trade, and sails remarkably fast." ${ }^{\prime 175}$ An equally zealous description is contained in the advertisement for the Olive Branch. ${ }^{176}$ The vessel, described as "high between Decks, well calculated for carrying Passengers, and the master experienced in the Trade", arrived in Belfast on 1 February from Baltimore with a shipment of tobacco

the Sally arrived 28 February from Liverpool with Capt. Conway at the helm. The New Lloyd's List issue dated 22 March 1785 shows the Sally with Conway as Captain departed for Baltimore on the $12^{\text {th }}$ of March 1785.

173 The vessel was scheduled to leave on 1 April but no listing for a departure appears in the Belfast News-Letter or New Lloyd's List for some considerable time either side of the proposed departure date. It is unclear what happened to the Paca.

${ }^{174}$ Belfast News-Letter noted the arrival as 2 February, New Lloyd's List dated 15 February concurred. ${ }^{175}$ New Lloyd's List dated 17 May 1785 lists the Friendship as sailed for Philadelphia 5 May 1785.

Weather may have delayed the departure or a lack of cargo/full contingent of passengers. The vessel's arrival date in Philadelphia is unclear.

${ }^{176}$ An American owned vessel of 120 tons, listed in New Lloyd's Register 1786 as built in America in 1782, and in A1 condition when surveyed on its outbound journey Liverpool/Maryland. 
and flaxseed as well as other goods ${ }^{177}$ and initially intended to depart for Baltimore on the $20^{\text {th }}$ of February. The vessel did not leave port, however, until 15 March "at the request of a number of the passengers."178

The short descriptions of cargoes reported by the Belfast News-Letter have allowed us to gauge the type of goods imported into Belfast. From herrings to cider, mahogany to rum, and on to iron, salt, wine, fruit and beer, bricks, tea, cod and ling, flour, vinegar, flagstones and soap, it is clear that there is a strong theme of utilitarianism to the goods arriving at the port. There are no black bear skins, plated shoe buckles, candlesticks or other ostentatious paraphernalia as seen in Eaton's list of goods imported into Dublin.

Belfast, with its smaller population base, imported a narrower variety of goods and exports were similarly varied. With the smaller market and narrower focus, it was possible for one merchant to dominate. In Belfast, that merchant was Waddell Cunningham - a well-known figure in mercantile, commercial, political and social circles. ${ }^{179} \mathrm{He}$ often traded in his own right, or as Waddell Cunningham \& Co., and later (and sometimes concurrently), in partnership with Thomas Greg, ${ }^{180}$ as Greg \& Cunningham. Cunningham had spent some time in provincial New York in the 1750s where he built up a considerable network of business and social contacts. When he returned to Belfast after several years in the American colonies those contacts became the framework for his very successful trans-Atlantic business operations. He acted as shipping agent, intermediary, merchant, wholesaler, took

\footnotetext{
177 Entry contained in the Belfast News-Letter arrivals list. The New Lloyd's List shows an arrival date of 11 February 1785 and a departure Wednesday 16 March. New Lloyds List of 14 June 1785 lists her arrival in Maryland.

178 These passengers were not likely to be migrants but instead Irish businessmen and women moving between the two markets. Gore's Liverpool Directory for 1790 lists the Dublin packet office as situated "No.5 Nova Scotia"; ibid, p.203; by 1800 it was situated at "No.1 Nova Scotia, facing the Graving Docks From when the following PACKETS sail nearly every Day between LIVERPOOL and DUBLIN, with elegant Accommodations, and carry Passengers, Horses, and carriages only." Gore's Liverpool Directory, for 1800, p.190.

179 Waddell Cunningham, Founder of the White Linen Hall in Belfast, charter member of the Belfast Harbour Corporation, trustee of the Second Presbyterian Congregation, promoter of the Belfast Academy, Linen Hall Library and the Belfast Charitable Society. Thomas M. Truxes, 'Cunningham, Waddell (1729-1797), Oxford Dictionary of National Biography, Oxford University Press, 2004 URL: http://www.oxforddnb.com/view/article/57700, accessed 25 November 2005.

180 Thomas Greg was Waddell Cunningham's brother-in-law.
} 
shares in the ownership of several vessels and hundreds, if not thousands, of cargoes. ${ }^{181}$ Of all the names that appear in the 1785 editions of the Belfast News-Letter "Mercantile Advertisements" column, and in the general body of the publication, these trading entities appear with the most frequency. ${ }^{182}$

In the absence of details on quantities and consignees of the goods moving in and out of Belfast, one must tally the number of advertisements in the Belfast NewsLetter to analyse seasonal trade patterns. From analysis of all the weekly issues from 1785 , more vessels move in and out of the port in the spring and summer months, than in autumn and winter - especially in the trans-Atlantic trade. Shipments of English coal arrived monthly peaking at 22 colliers arriving in Belfast on one day in February. Herrings arrived in February and March but none appeared in the lists at any other time. Iron arrived in the early months of the year but not the latter half. Sugar from Liverpool arrived in Belfast frequently - but only direct from the Caribbean in summer. The advertisements followed the same pattern; masters and agents seeking outbound cargoes increased the number of advertisements over the spring and summer months, and as inbound cargoes arrived the variety and number of merchants advertising goods for sale followed the upward trend. As in the port of Liverpool, there was pronounced seasonality in shipping movements. ${ }^{183}$

As to the street locations of business premises, in the absence of trade or street directories for this period, ${ }^{184}$ it is fortunate that some advertisements included street names. For example, Robert and Hugh Hyndman listed their address as "No. 22, Bridge-street, Belfast" when they advertised their new shipment of Teas for sale in the March 4 edition. John Hyndman, the agent for the Sally, listed his address as 'Bridge-street' - he possibly operated from the same premises as Robert and Hugh, or at least very close to No. 22. Capt. Moore and Mr Robert Moore (possibly the same person) operated from premises "on the Quay." The agent for the Paca,

\footnotetext{
${ }^{181}$ Cunningham died a relatively rich man in 1797 . The recorded value of his estate, excluding a sugar plantation on the island of Dominica, is $£ 60,000$. Truxes cites source of this information as PRONI ref. CR 4/9B/13.

182 In 1800, the name Henry Haslett appears most frequently in the shipping notices.

183 Stephen D. Behrendt, 'Markets, Transaction Cycles, and Profits: Merchant Decision Making in the British Slave Trade,' William \& Mary Quarterly, Vol. LVIII, January 2001, p.177.

${ }^{184}$ It is the lack of extant copies that hinders this part of the study.
} 
Matthias Maris, listed his address as care of "Mr Samuel Ferguson's house in MillStreet", and Capt. Robert Caulfield's as care of "Mr Thos Scott's in North-street."

In June, Alex Nicholson advertised that an auction of slates would take place "upon Hanover Quay" — perhaps the site of an established auction house. In an advertisement dated 3 June 1785, James Boyd (a tobacco and snuff manufacturer) advised his customers he had moved from Five-mile-row to North-street, Belfast. ${ }^{185}$ In an advertisement dated 13 November 1800, John Boyd advertised his premises as "No. 11, Hanover-Quay, Belfast" and Andrew Thomson, importer of 'strong Jamaica rum' operated from 'High-street'. Narcissus \& Robert Batt, who imported a variety of goods such as 'New York and Boston pot-ashes' and 'Dutch Starch', listed their premises as Calendar-street, Belfast. Robert Getty listed his auction premises as North-street in 1800. Bridge-street, North-street and High-street were all located near the docks.

Although the information from the Belfast News-Letter and New Lloyd's List is somewhat limited, it shows a community of merchants that is small in number in 1785 , and who dealt with a relatively limited range of goods for export. Unlike the larger merchant communities of Dublin and Liverpool, the return cargoes imported by the Belfast merchants were utilitarian and limited in the range of goods handled. ${ }^{186}$ Many of the goods imported fed and housed the increasing population, who in turn made up the labour force of the main and fastest growing industry of the northern counties - linen.

\section{- IV -}

\section{The Merchant Community of Liverpool}

Detailed shipping information in the Manchester Mercury allows one to identify many Liverpool merchants, their trading patterns, and their links to Dublin and Belfast. According to Clemens, "a mercantile oligarchy of roughly two dozen men"

\footnotetext{
${ }^{185}$ Only one advertisement appeared in the 1785 issue; the advertisements in the 1800 issue were used to indicate what sort of information can be obtained from the advertisements, about the activities of the merchants and were they operated their businesses.

186 Truxes concluded that in the period up to the American Revolution "her overseas trade was considerably more diverse than that of her rival ports, Derry and Newry"; Truxes, Irish-American Trade, p.79.
} 
controlled Liverpool's economy in the latter half of the eighteenth century. ${ }^{187}$ Merchants Ansdell, Cazneau \& Marlin, Benson, Fleetwood, Gaskell, Green, North, and Wharton each received more than forty consignments of the 1,609 that arrived from Irish ports in $1770 .{ }^{188}$ The Tarletons, Pembertons, Rathbones, Crosthwaits, and Atkinsons frequently appear as consignees to goods arriving from the Caribbean and American Colonies.

In 1785, John and James Ansdell brokered 53 Irish consignments reported in the Manchester Mercury:; 28 consignments arrived from Dublin and two from Belfast, while the majority of the other 23 came from the port of Drogheda. Neither Ansdell appears in Bailey's Northern Directory of 1783. According to the shipping reports of 1770 a John Ansdell (probably related to James - possibly a brother, or father or uncle) imported goods into Liverpool from Ireland.

Thomas Leyland imported 32 consignments of Irish goods into Liverpool in 1785, three years after he organised his first slaving voyage. In the 1790s Leyland expanded his slave trading business and in 1798 became mayor of Liverpool for the first of three separate terms. In 1789, however, his business interests focussed on Irish Sea trades. ${ }^{189}$

The partnership of Cazneau \& Marlin jointly and severally appeared in the shipping reports 37 times in 1785. Bailey's Directory lists Joseph Cazneau as a merchant in “Hanover street," Liverpool in $1783 .{ }^{190}$ Of the 25 consignments arrived from Belfast consigned to 'Cazneau \& Marlin' in 1785, eight were linen cloth. Bailey's Directory of 1783 listed Ayton Marlin as a merchant in Duke Street. ${ }^{191}$

Henry Delamaine appeared as a consignee no less than 25 times in 1785 but his business profile remains a mystery. He is not listed in any trade directory but he takes delivery of a wide variety of goods and obviously deals in produce as well as

\footnotetext{
${ }^{187}$ Clemens, 'The Rise of Liverpool', p.216.

${ }^{188}$ From Manchester Mercury arrival notices.

189 Thomas Leyland (c.1752-1827) was a merchant, banker, millionaire and three times Mayor of Liverpool. In 1766 he won a lottery prize of $£ 20,000$, which he used to build up his business affairs. He was involved in various trading partnerships. He built up much of his mercantile fortune from participation in the slave trade, and was particularly active in that traffic as well in various other trades in the last two decades of the eighteenth century. URL:

http://www.britishonlinearchives.co.uk/group.php?cat=\&sid=\&cid=9781851171477\&date_option=equal \&page=\&pid=147-leyland, accessed 7 December 2007.

${ }^{190}$ Bailey's Directory.

191 Ibid, p.237.
} 
general goods. There are consignments of beef, bacon, butter, coney wool, ox horns, quills, skins, corks, hides, flour, feathers and glue. All of the goods come from Dublin and the importations occurred between February and October of $1785 .{ }^{192}$ The partnership Holmes \& Delamaine imported 26 consignments in the same period the majority of which came from Dublin also. The type of goods imported includes beef, skins, applies and tongues. It is unclear whether there is a connection between Henry Delamaine and this partnership, but as Clemens pointed out Liverpool was a small mercantile community and it would be unusual if there were not a connection. Bailey's 1783 directory of merchants for Liverpool contains only one-tenth the listings for Liverpool than for London. Though Liverpool was the second busiest port in the British Isles in the 1780s, the port's population was 75,000 - one-twelfth of London.

There are several other merchants with similar sized operations to those of Delamaine. One of these was the partnership of Dickson \& Pemberton. ${ }^{193}$ This is either John or William Dickson, both of whom are listed as merchants in the 1783 Directory $^{194}$ and possibly John Pemberton, merchant with offices at 21, Crooked lane, Old Dock. Joshua Holt, a merchant of Freemason row, Vauxhall Road imported 23 consignments of goods from Ireland, 11 of which came from Belfast and totalled 2,389 firkins and 569 casks of butter. ${ }^{195}$ Mason \& Bourne, listed as merchants of Shaw's Alley in 1783, imported 28 consignments - all from Wexford and all oats. Wagners \& Brown imported 26 consignments and William Wallace 25. Henry Wharton ('broker, Park lane' according to the 1783 Directory) imported $29-12$ of which arrived in Liverpool from Dublin. He dealt in large quantities of bay yarn (all of which came from Dublin), butter, and linen-cloth/linen-yarn from Drogheda, Dublin and Londonderry.

\footnotetext{
192 Information gathered from the Manchester Mercury shipping reports of the goods discharged in Liverpool with an Irish port as the last port of lading.

193 This partnership is recorded variously as 'Dixon \& Pemberton' and 'Dickson \& Pemberton.' ${ }^{194}$ John Dickson, merchant, Preeson's Row; William Dickson, merchant, Clayton square, Liverpool; Bailey's Directory, p.252.

195 There is also a Thomas Holt who imported four consignments of linen-cloth from Drogheda. He has been listed as a 'Glass warehouse, Hanover Street' in 1783 and as a cooper of Hanover street, in 1800. It would seem that these are not the same persons.
} 
The largest number of consignments of all types of goods (100) recorded as arrived from any of the Irish ports of lading, were consigned to John Thomas. Most consignments were grains or seeds - barley, oats, rapeseed, rye, or wheat. He did import some pork, beef, tallow, hams and butter also. Unusually for such a busy trader his name does not appear in the 1783 Directory. He sourced the majority of his beef imports from Dublin and his oats from Dungarvon, Limerick, and Wexford.

The next largest number of consignments (72) arrived in the names of George or John or Samuel Green - the latter importing 60 consignments in his own right. In 1783, George was listed as a distiller with premises in Duke street. Neither John nor Samuel appeared in the 1783 listings. Samuel imports large numbers of packs and trusses of bay yarn, linen-cloth and linen-yarn from several places; 39 consignments of goods come from Dublin, only four from Belfast and several from Drogheda, Sligo, Londonderry, and Coleraine. ${ }^{196}$

Close to the number of imports made by Samuel Green is John Smith with 56 consignments in 1785 . As this is a common name, and the variety of goods imported may represented more than one importer by the name of John Smith, the name is noted but further investigation would be required before any valid conclusions could be drawn from the data. There is only one 'John Smith' listed in the 1783 Directory.

There is no dominant merchant buying goods from Belfast in 1770; James Blair and Robert Morris each have eight of the 163 consignments arrived in Liverpool from Belfast. However, in 1785 Cazneau \& Marlin dominate with 25 shipments from Belfast; Warbrick \& Holt are ranked second. Morris \& Leicester, William Williamson, Joshua Holt, George Marsden all buy ten or more consignments each.

\footnotetext{
196 Samuel Green appears as a major importer of yarn and cloth in the 1770 shipping records, moving large quantities of bay yarn and line yarn/cloth from Dublin into Liverpool. To unravel the familial or business connections between the three Green's listed in the 1785 shipping records would require some more in-depth research, and is not within the terms of reference of this thesis. The main point here is that Samuel Green was a major importer of goods from Ireland into the port of Liverpool in 1785.
} 
The 'concentration ratio' of a market is used by economic historians to identify who the largest firms in the market are, what percentage share of the market they control, and thus how competitive the market is. In this last section of the chapter, I have used the figures from my database of imports into Liverpool from Ireland to determine who in Liverpool controlled the imports of two of the key commodities identified in Table 1.6 (Chapter One of this thesis) - butter and linen cloth.

I have used the CR4 and CR8 formulae, calculating the market shares based on the top four and top eight importers. Normally, a market is considered to be "highly concentrated" if CR4 greater than or equal to 50 percent or the CR8 is greater than or equal to 75 percent. A "moderately concentrated" market is one where the CR4 equals between 34 percent and 49 percent (the CR8 figures would be 51 to 74 percent, and the "lowly concentrated" market is where the CR4 figure is less than or equal to 33 percent (CR8 less than or equal to 50 percent). ${ }^{197}$

Let us begin our investigations into the market concentrations with a discussion of the export market for Dublin. The discussion will be limited to the two key commodities, butter and linen cloth and will focus on the four leading exporters of each commodity, that is, the CR4 analysis. Information concerning market concentrations for the goods exported from Dublin comes from Eaton's "List" and therefore only covers the first quarter of $1785 .{ }^{198}$ Nevertheless, the information is interesting and provides some insight into the activities of the Dublin trading community. The CR4 concentration ratios for the exporters of butter and linen cloth (not for bounty) identified in Eaton's "List" are as follows:

\footnotetext{
197 This analysis does not take into consideration the size of the firms, merely their market share based on the number of consignments they received from Ireland. The Herfindahl-Hirschman Index (which would overcome this problem) will not be applied to the data for this thesis. URL http: www.quickmba.com/econ.miro/indcon.shtml, accessed 7 December 2007; Colin Hoskins, Stuart McFadyen, and Adam Finn, Media Economics: Applying Economics to New and Traditional Media, Thousand Oaks, Calif., 2004, p.146.

${ }_{198}$ Regrettably, no documentation exists for exports from Belfast that would allow for similar calculations to be carried out.
} 
Table 4.1: Concentration ratios, exports of butter and linen cloth from Dublin to all destinations in the first quarter of $\mathbf{1 7 8 5 .}$

\begin{tabular}{|c|c|c|c|}
\hline Commodity / merchant & Rank & Total exported & $\%$ of total exported \\
\hline Butter (cwt/qr/lbs) & & Total 4,581:1:25 & \\
\hline Thomas Nowlan & 1 & $868: 2: 0 \mathrm{cwt}$ & $19 \%$ \\
\hline Lewis \& Peter Tourtellott & 2 & 639:0:19 & $14 \%$ \\
\hline John Darragh & 3 & 589:1:0 & $13 \%$ \\
\hline Anthony McDermott & 4 & 500:0:0 & $11 \%$ \\
\hline Total no. of merchants & 26 & & $57 \%$ \\
\hline Linen - for Bounty (yards) & & Total 270,003 & \\
\hline Dunn, Hinck \& O’Brien & 1 & 110,441 & $41 \%$ \\
\hline Smith Ramadge & 2 & 35,595 & $13 \%$ \\
\hline T. Mitchell \& J. Anderson & 3 & 26,789 & $10 \%$ \\
\hline O'Brien \& Comerfords & 4 & 25,474 & $9 \%$ \\
\hline Total no. of merchants & 10 & & $73 \%$ \\
\hline Linen - not for Bounty (yards) & & Total 7,918,911 & \\
\hline Robert Malkin & 1 & 840,000 & $10.6 \%$ \\
\hline Hugh Crothers & 2 & 825,000 & $10.4 \%$ \\
\hline Hugh Hamill \& Co & 3 & 820,000 & $10.3 \%$ \\
\hline James Sheil & 4 & 807,500 & $10.2 \%$ \\
\hline Total no. of merchants & 33 & & $51.5 \%$ \\
\hline
\end{tabular}

Source: Eaton's “List”

With the CR4 concentration ratios all greater than 50 percent, the markets are "highly concentrated." Thomas Nowlan exported only one consignment of butter (destined for London) in the first quarter and it was such a large amount of butter the figure represents one fifth of the total butter exports. Only five consignments of butter, averaging approximately 27cwt each, left Dublin for Liverpool in the three months to March 1785. Merchant Sam Stephens despatched two consignments, and John Stephens, Thomas Corbett, and David Melville each sent one.

The four leading merchants trading linen cloth (not for bounty) each exported a little over ten percent of the total despatched to all destinations from Dublin in the first quarter of 1785 . Fifteen consignments, totalling 1,990,647 yards, are despatched to Liverpool; the range of the consignment size is from 200 yards to 370,000 yards and twelve exporters facilitate the trade. T. \& J. Nicholson, 
M[ontgomery] Crothers, and George Overend each send two consignments; Nicholson's total 325,000 is yards and Overend's total is 340,000 yards but Crothers' total is 350,000 yards. Wm. \& Nathaniel Gould, however, consign a single shipment of 370,000 yards to Dublin. None of these exporters appear in the list of the top four (CR4) merchants because the analysis is skewed by the fact that Eaton's "List" covers only one quarter of a complete year.

While the concentration ratio analysis for exports from Dublin is of interest, the earlier analysis of Eaton's figures using collated data is of more relevance of the discussion of Dublin's exports and imports and the merchant communities it interacted with. That research showed that overall, Liverpool was the key market for goods despatched from Dublin. Let us, therefore, now consider the concentration ratio for imports into Liverpool from Ireland for the two key commodities — butter and linen cloth (not for bounty).

The data extracted from the shipping reports of the Manchester Mercury revealed a total of $1,860,2041 \mathrm{bs}$ of butter arrived in Liverpool from Ireland in 1785. ${ }^{199}$ There are 83 trading entities listed as consignees for the butter consignments. Table 4.2 ranks the top eight importers, the total amount of butter they imported and their percentage share of total imports.

In 1785, the four leading importers (CR4) controlled 42 percent and only three importers have ten percent or more of the total. The top eight importers (CR8) controlled 59 percent of the total amount of butter imported from Ireland into Liverpool in 1785 . The remaining 75 importers import 41 percent of the total about 1.5 percent or approximately $2,500 \mathrm{lbs}$ of butter each. ${ }^{200}$

Of the total imports, the following individual importation patterns emerged: Joshua Holt imported 12 percent of the total - 197,512lbs from Belfast, 3,332lbs from Dublin and 16,800lbs from Newry. The four leading importers received the following quantities: Morris \& Leicester imported 123,732lbs from Belfast, 85,820lbs from Larne, and 8,400lbs from Newry; George Marsden imported 186,732lbs from

\footnotetext{
199 The unit of measurements has been converted (using Zupko's equivalencies) to the lowest common denominator - lbs.

${ }^{200}$ Butter arrived from twelve ports in Ireland. Only 280lbs of butter was imported from Coleraine and 672lbs from Drogheda.
} 
Belfast and 2,856lbs from Newry; Warbrick \& Holt only imported only eight percent of the total amount of butter arrived in Liverpool from Belfast in 1785 (139,580lbs).

Of the imports from Dublin into Liverpool, the four leading consignees (CR4) were Dickson \& Pemberton, John Smith, H. Delmaine, and John Thomas. For butter imported into Liverpool from Belfast the leading four importers (CR4) were Joshua Holt, George Marsden, Warbrick \& Holt, and Morris \& Leicester.

Table 4.2: Liverpool: summary of butter market concentration ratios for 1770 and 1785.

\begin{tabular}{|c|c|c|c|c|c|}
\hline \multicolumn{3}{|c|}{1770} & \multicolumn{3}{|c|}{1785} \\
\hline $\begin{array}{l}\text { Liverpool Consignee } \\
\text { (Importer/Agent) }\end{array}$ & $\begin{array}{l}\text { Total } \\
\text { lbs }\end{array}$ & $\begin{array}{l}\% \text { of } \\
\text { total }\end{array}$ & $\begin{array}{l}\text { Liverpool Consignee } \\
\text { (Importer/Agent) }\end{array}$ & $\begin{array}{l}\text { Total } \\
\text { lbs }\end{array}$ & $\begin{array}{l}\% \text { of } \\
\text { total }\end{array}$ \\
\hline John Benson \& Co. & 121,352 & $9 \%$ & Joshua Holt & 229,012 & $12 \%$ \\
\hline Thomas Gaskell & 82,544 & $6 \%$ & Morris \& Leicester & 217,952 & $12 \%$ \\
\hline John North & 71,456 & $5 \%$ & George Marsden & 189,588 & $10 \%$ \\
\hline Robert Morris & 69,384 & $5 \%$ & Warbrick \& Holt & 139,580 & $8 \%$ \\
\hline Bailie \& Lloyd & 62,104 & $4 \%$ & Cazneau \& Marlin & 94,668 & $5 \%$ \\
\hline John Harper & 55,048 & $4 \%$ & Sarah Wagstaff \& Co. & 88,424 & $5 \%$ \\
\hline Whitaker \& White & 44,464 & $3 \%$ & William Williamson & 70,252 & $4 \%$ \\
\hline James Blair & 43,176 & $3 \%$ & Thomas Whitwell \& Co. & 61,488 & $3 \%$ \\
\hline CR4 & & $25 \%$ & CR4 & & $42 \%$ \\
\hline CR8 & & $39 \%$ & CR8 & & $59 \%$ \\
\hline
\end{tabular}

The butter market in 1785 was "moderately competitive" and these figures reflect the relative ease with which an importer could enter this sector of the import markets. It would seem that any merchant wishing to import butter from Ireland into Liverpool could do so and that no single merchant had a monopoly on the market.

By contrast, in 1770 the market for butter imported from Ireland was "lowly concentrated." Butter arrived in Liverpool from sixteen ports. A total of 1,409,132lbs arrived, consigned to 96 different trading entities. The quantities and percentages are tabulated from the shipping reports and appear here as Table 4.3. The top four importers (CR4) received only one quarter of the total amount of butter arrived in Liverpool. No one trading entity received more than nine percent of the total and the leading eight consignees took delivery of only 39 percent of the total. Thus the 
remaining 88 trading entities were consigned 61 percent of the total amount of butter imported into Liverpool from Ireland in 1770.

Bailie and Lloyd, Dickson \& Melling, Richard Kent, and Whitaker \& White were the leading four entities in Liverpool that imported butter from Dublin. James Blair, Thomas Gaskell, Robert Morris, and Arnold Meyer imported their consignments of butter from Belfast. The individual importing patterns of the four main recipients of the total imports are as follows: John Benson \& Co. imported nine percent of the total $-95,816 \mathrm{lbs}$ from Sligo, 12,880lbs from Belfast, and 3,920lbs from Londonderry; Thomas Gaskell received 41,944lbs from Belfast, 25,928lbs from Newry, 10,640lbs from Coleraine, 3,920lbs from Waterford, and 112lbs from Wexford; Ranked third, John North (with five percent of the total) was the consignee for $28,336 \mathrm{lbs}$ from Cork, 25,200lbs from Belfast, and 17,920lbs from Waterford; Robert Morris imported 39,536lbs from Belfast, 22,288lbs from Sligo, and 7,560lbs from Newry.

Table 4.3: Liverpool: summary of quantities of butter imported from Ireland by port of lading, 1770 and 1785.

\begin{tabular}{|c|c|c|c|c|c|}
\hline \multicolumn{3}{|c|}{1770} & \multicolumn{3}{|c|}{1785} \\
\hline Total imported & $1,409,132 \mathrm{lbs}$ & & Total imported & $1,860,204 \mathrm{lbs}$ & \\
\hline Ex Belfast (1st) & $475,776 \mathrm{lbs}$ & $33 \%$ & Belfast $\left(1^{\text {st }}\right)$ & $1,262,576 \mathrm{lbs}$ & $68 \%$ \\
\hline Ex Dublin $\left(7^{\text {th }}\right)$ & $24,444 \mathrm{lbs}$ & $2 \%$ & Dublin $\left(5^{\text {th }}\right)$ & $45,892 \mathrm{lbs}$ & $3 \%$ \\
\hline Other ports (ranked) & & $65 \%$ & Other ports (ranked) & & $29 \%$ \\
\hline Cork $\left(2^{\text {nd }}\right)$ & $274,008 \mathrm{lbs}$ & & Newry (2nd) & $260,568 \mathrm{lbs}$ & \\
\hline Sligo (3rd) & $185,248 \mathrm{lbs}$ & & Cork $\left(3^{\text {rd }}\right)$ & $154,952 \mathrm{lbs}$ & \\
\hline Waterford $\left(4^{\text {th }}\right)$ & $162,228 \mathrm{lbs}$ & & Larne $\left(4^{\text {th }}\right)$ & $88,676 \mathrm{lbs}$ & \\
\hline Newry $\left(5^{\text {th }}\right)$ & $118,832 \mathrm{lbs}$ & & Sligo $\left(6^{\text {th }}\right)$ & $19,376 \mathrm{lbs}$ & \\
\hline Strangford ( $\left.6^{\text {th }}\right)$ & $90,104 \mathrm{lbs}$ & & Limerick ( $\left.7^{\text {th }}\right)$ & $9,184 \mathrm{lbs}$ & \\
\hline Coleraine $\left(8^{\text {th }}\right)$ & $19,376 \mathrm{lbs}$ & & Strangford $\left(8^{\text {th }}\right)$ & $8,540 \mathrm{lbs}$ & \\
\hline
\end{tabular}

Butter, is therefore, an example of the tightening of a market sector over time. In 1770, 96 trading entities participate in the market. The leading eight controlled 39 percent of the total imports but no one merchant imported more than nine percent of the total. In 1785 only 88 merchants import butter from Ireland. The CR8 figure is increased to 59 percent and the top three importers each import ten percent or more of the total imports. The top three have therefore gained a larger share of the butter 
importation sector. No one merchant is entirely dominant; there is no monopoly or oligopoly.

The analysis for the second key commodity — linen cloth — revealed the following figures and patterns. Tables 4.4 and 4.5 are the summations of the data for linen cloth importations into Liverpool from Ireland for 1770 and 1785. In 1785, a total of 1,411,400 yards of linen cloth arrived in Liverpool from Ireland. The top four importers (CR4) controlled 31 percent of the imports and no one merchant received more than nine percent of the linen cloth. The leading eight imported (CR8) controlled 53.5 percent of the total amount of linen cloth imported from Ireland into Liverpool in 1785. The remaining 301 trading entities imported 46.5 percent of the total. The CR4 is "lowly concentrated" but the CR8 percentage pushes the market into the "moderately concentrated" parameters.

Table 4.4: Liverpool: summary of quantities of linen cloth imported from Ireland, by port of lading, 1770 and 1785.

\begin{tabular}{|c|c|c|c|c|c|}
\hline \multicolumn{3}{|c|}{1770} & \multicolumn{3}{|c|}{1785} \\
\hline Total imported & $1,533,650 \mathrm{yds}$ & & Total imported & $1,411,400 \mathrm{yds}$ & \\
\hline Ex Belfast $\left(4^{\text {th }}\right)$ & $167,225 \mathrm{yds}$ & $11 \%$ & Belfast (2nd) & $403,200 \mathrm{yds}$ & $29 \%$ \\
\hline Ex Dublin $\left(1^{\text {st }}\right)$ & $677,500 \mathrm{yds}$ & $44 \%$ & Dublin $\left(1^{\text {st }}\right)$ & $575,525 \mathrm{yds}$ & $41 \%$ \\
\hline Other ports (ranked) & & $45 \%$ & Other ports (ranked) & & $30 \%$ \\
\hline Newry $\left(2^{\text {nd }}\right)$ & $433,425 \mathrm{yds}$ & & Drogheda $\left(3^{\text {rd }}\right)$ & $360,625 \mathrm{yds}$ & \\
\hline Drogheda $\left(3^{\text {rd }}\right)$ & $187,200 \mathrm{yds}$ & & Newry $\left(4^{\text {th }}\right)$ & $18,800 \mathrm{yds}$ & \\
\hline Strangford $\left(5^{\text {th }}\right)$ & $42,175 \mathrm{yds}$ & & Strangford $\left(5^{\text {th }}\right)$ & $15,400 \mathrm{yds}$ & \\
\hline Londonderry $\left(6^{\text {th }}\right)$ & $23,050 \mathrm{yds}$ & & Londonderry $\left(6^{\text {th }}\right)$ & $14,300 \mathrm{yds}$ & \\
\hline
\end{tabular}

Table 4.5: Summary of linen cloth market concentration ratios for $\mathbf{1 7 7 0}$ and $\mathbf{1 7 8 5 .}$

\begin{tabular}{|c|c|c|c|c|c|}
\hline \multicolumn{3}{|c|}{1770} & \multicolumn{3}{|c|}{1785} \\
\hline $\begin{array}{l}\text { Liverpool Consignee } \\
\text { (Importer/Agent) }\end{array}$ & $\begin{array}{l}\text { Total } \\
\text { yds }\end{array}$ & $\begin{array}{l}\% \text { of } \\
\text { total }\end{array}$ & $\begin{array}{l}\text { Liverpool Consignee } \\
\text { (Importer/Agent) }\end{array}$ & $\begin{array}{l}\text { Total } \\
\text { yds }\end{array}$ & $\begin{array}{l}\% \text { of } \\
\text { total }\end{array}$ \\
\hline Blundell \& Crosbie & 154,300 & $10 \%$ & George Goring & 123,600 & $9 \%$ \\
\hline John Benson \& Co. & 138,250 & $9 \%$ & Venables \& Taylor & 108,600 & $8 \%$ \\
\hline Benson \& Postlethwaite & 119,600 & $8 \%$ & J Ansdell & 97,000 & $7 \%$ \\
\hline William Wallace & 114,800 & $7 \%$ & Samuel Green & 92,700 & $7 \%$ \\
\hline Thomas Gaskell & 91,800 & $6 \%$ & Thomas Fleetwood & 90,600 & $6 \%$ \\
\hline Thomas Parke \& Co. & 85,800 & $6 \%$ & Cazneau \& Marlin & 87,600 & $6 \%$ \\
\hline William Lightbody \& Co. & 78,200 & $5 \%$ & R. \& J. Lightbody & 78,600 & $5.5 \%$ \\
\hline Thomas Parke & 50,400 & $3 \%$ & Parker \& Son & 72,700 & $5 \%$ \\
\hline CR4 & & $34 \%$ & CR4 & & $31 \%$ \\
\hline CR8 & & $54 \%$ & CR8 & & $53.5 \%$ \\
\hline
\end{tabular}


Of the total imports, the following individual importation patterns emerged: George Goring imported 112,000 yards from Belfast and 11,600 yards from Drogheda; Venables \& Taylor received 108,600 yards from Dublin; J. Ansdell was consigned 59,200 yards from Drogheda, 31,600 yards from Dublin, 3,900 yards from Belfast, 1,300 yards from Londonderry, and 1,000 yards from Newry; Samuel Green received 40,000 yards of linen cloth from Belfast, 32,400 yards from Dublin, 19,000 yards from Drogheda, and 1,300 yards from Londonderry. The four leading consignees (CR4) of imports of linen cloth from Dublin were Venables \& Taylor, R. \& J. Lightbody, Parker \& Swan, and Samuel Green while the four top importers of linen cloth from Belfast were George Goring, Cazneau \& Marlin, Samuel Green, and Warbrick \& Holt.

The linen cloth importers had little or no impediment to their participation in the market - as evident by the very large number of importers. In 1770 there were 369 importers involved in the importation of the 1,533,650 yards of linen cloth arrived at Liverpool from Ireland. The leading eight importers (CR8) received 54 percent of the total amount and thus the remaining 361 importers were consigned 46 percent. The top four trading entities (Blundell \& Crosbie, John Benson \& Co., Benson \& Postlethwaite, and William Wallace) controlled 34 percent of the market sector with each merchant receiving between seven and ten percent (only Blundell \& Crosbie was consigned ten percent). The Liverpool merchants controlling the imports from Dublin were Blundell \& Crosbie, Thomas Parke \& Co., William Lightbody \& Co., and William Wallace. The leading four recipients (CR4) of the linen cloth from Belfast were James Suffern, William Haliday \& Co., John Benson \& Co., and Hugh Pringle.

Individual patterns of importation of the CR4 were as follows: Blundell \& Crosbie sourced 120,200 yards of linen cloth from Dublin, 19,200 yards from Newry, 11,600 yards from Drogheda, 2,000 yards from Dundalk, and 1,300 yards from Belfast. John Benson \& Co. received consignments totalling 97,900 yards from Newry, 22,900 yards from Belfast, 16,750 yards from Londonderry, and 3,300 yards from Dublin; Benson \& Postlethwaite imported 109,300 yards from Newry, 8,000 yards from Dublin, and only 2,300 yards from Londonderry. William Wallace took 
delivery of 60,900 yards from Newry, 47,400 yards from Dublin, 9,100 yards from Belfast, and 3,900 yards from Waterford.

Table 4.6: Concentration ratios, $\mathbf{1 7 8 5}$ compared for butter and linen

\begin{tabular}{|c|c|c|c|c|c|}
\hline \multicolumn{3}{|c|}{ Linen - 1785} & \multicolumn{3}{|c|}{ Butter - 1785} \\
\hline $\begin{array}{c}\text { Consignee } \\
\text { (Importer/Agent) }\end{array}$ & $\begin{array}{c}\text { Total } \\
\text { yds }\end{array}$ & $\begin{array}{l}\% \text { of } \\
\text { total }\end{array}$ & $\begin{array}{c}\text { Consignee } \\
\text { (Importer/Agent) }\end{array}$ & $\begin{array}{c}\text { Total } \\
\text { lbs }\end{array}$ & $\begin{array}{l}\% \text { of } \\
\text { total }\end{array}$ \\
\hline \multicolumn{3}{|c|}{ No. of merchants importing linen cloth $=369$} & \multicolumn{3}{|c|}{ No. of merchants importing butter $=83$} \\
\hline George Goring & 123,600 & $9 \%$ & Joshua Holt & 229,012 & $12 \%$ \\
\hline Venables \& Taylor & 108,600 & $8 \%$ & Morris \& Leicester & 217,952 & $12 \%$ \\
\hline J Ansdell & 97,000 & $7 \%$ & George Marsden & 189,588 & $10 \%$ \\
\hline Samuel Green & 92,700 & $7 \%$ & Warbrick \& Holt & 139,580 & $8 \%$ \\
\hline Thomas Fleetwood & 90,600 & $6 \%$ & Cazneau \& Marlin & 94,668 & $5 \%$ \\
\hline Cazneau \& Marlin & 87,600 & $6 \%$ & Sarah Wagstaff \& Co. & 88,424 & $5 \%$ \\
\hline R. \& J. Lightbody & 78,600 & $5.5 \%$ & William Williamson & 70,252 & $4 \%$ \\
\hline Parker \& Son & 72,700 & $5 \%$ & Thomas Whitwell \& Co. & 61,488 & $3 \%$ \\
\hline CR4 & & $31 \%$ & CR4 & & $42 \%$ \\
\hline CR8 & & $53.5 \%$ & CR8 & & $59 \%$ \\
\hline
\end{tabular}

Comparing the butter and linen sectors (Table 4.6) reveals that more importers in Liverpool traded linen than butter from Ireland. Only one merchant featured in both lists as a leading importer - Cazneau \& Marlin. As a perishable commodity, butter was a higher risk commodity than linen cloth but it was a consumable and thus high turnover. Linen cloth was available all-year round, in large quantities, and was a low-risk commodity.

We now know who the leading merchants were in 1785 in Dublin, what market sectors were controlled by which merchant, and what commodities they imported or exported. The number of merchants participating in the markets increased over time in some sectors. Most appear to be general merchants who traded different commodities and who, often, did not attain 'leading merchant' status within that commodity sector.

The mercantile and commercial environment for 1785 was compared to that of 1770 and any changes noted. The greatest amount of information obtained, however, came from the analysis of the market information for imports into Liverpool from Ireland in 1785, and again it was compared to 1770 to gauge 'change 
over time.' This section of the thesis has added much to the historiography of Ireland's commercial and mercantile interaction with England through the port of Liverpool. 


\section{Conclusion}

Historians studying eighteenth-century Irish economic history have based conclusions on well-known annual customs data for commodities exported and imported out of and into Ireland. The newly discovered Eaton's quarterly "List" with daily details on the exports and imports (grouped by commodity) of the port of Dublin is unique and therefore a significant find. Other lists, presumably written by other customs officials, remain undiscovered. No comparable daily list of exports and imports has been found for any other British or Irish port.

There are micro-histories, business histories and biographies of merchants but most concern nineteenth century businessmen. We still know very little about the everyday operations of the Irish merchants, who they traded with and what percentages of goods went to which markets. The most important work on eighteenth century merchants and Irish-American trade, Thomas Truxes's IrishAmerican Trade, 1660-1783 (Cambridge, 1988), focuses on the larger merchants, such as Waddell Cunningham, trading out of Belfast and his work ends before our survey year 1785. A large firm such as Cunningham's would have been unable to achieve the market power it gained in Belfast, in the larger merchant community of Dublin. We are, therefore, still lacking a comprehensive work on the Dublin merchant community and their activities in the eighteenth-century. This MA thesis goes some way towards filling the gap in the historiography.

Because of the lack of detailed evidence, at present no one piece of work conveys the scope or scale of how groups of merchants traded, and the analysis of the aggregated totals reveals only broad trends and generalisations for the whole of Ireland. With the newly discovered Eaton's "List" of imports and exports into and out of Dublin for the first quarter of 1785, we have, for the first time, detailed evidence of the trading activities of a series of merchants. The data have been collated and tallied. Patterns of trade, market structures, market shares, and market concentrations have all been determined. 
The data from Eaton's "List" have been supplemented with the shipping reports contained in the Irish and Lancashire newspapers. The details of shipping movements, cargoes and consignees in the Manchester Mercury, Freeman's Journal of Dublin, and the Belfast News-Letter were added to my database and then analysed. As a result, we now have a better understanding of the structure and operations of the merchant communities of Dublin, Belfast and Liverpool and the interaction of all three, not only in 1785 but in 1770 as well.

In the first chapter of this thesis, I discussed the information contained in Eaton's "List." I emphasised how important the detail of the document was to our knowledge of the scale and scope of Ireland's exports and imports in the eighteenth century. I analysed the information and discussed the evidence, or lack thereof, of patterns of trade. I cross-checked the results and supplemented the data with information from New Lloyd's List and Lloyd's Register of Shipping and included biographical data from Dublin and Liverpool directories. This research ensured that I created as complete a micro-history as possible about Dublin's trade during the first quarter of 1785 .

In the second chapter, I supplemented the data abstracted from Eaton's "List" with data gathered from the Freeman's Journal of Dublin, Belfast News-Letter, and Manchester Mercury. In addition to analysing all extant issues from 1785, I collated information from 1770 to enable comparisons to be made and to assess 'change over time.' Dublin was compared with Belfast and the interaction with Liverpool discussed. Creating a large database enabled me to ascertain patterns of trade and market structures for 1770 and 1785 . For a small number of cargoes I was even able to match up the Dublin exporter with the Liverpool importer.

Chapter Three analysed trade to and from the largest market for goods despatched from Ireland (England) and the second most important port (Liverpool). Two-thirds of all exports from Dublin in the first quarter of 1785 were despatched to English ports. There were three main categories of commodities: primary produce and by-products; linen yarn and linen products; and "merchants' goods." Dublin merchants exported 462 consignments of these categories of goods, and 41 percent 
of the consignments were destined for the port of Liverpool. Of all the goods that arrived at Liverpool consigned from Ireland in 1785, 20 percent was linen cloth, 18 percent was butter, 11 percent was linen yarn and the remaining goods other 'primary produce or by-products.' We confirmed that agricultural produce was by far the largest export from Ireland. By utilising the works of Sir Charles Whitworth (1776), Alice Murray (1903), Elizabeth Schumpeter (1960), Louis Cullen (1968) and Thomas Truxes (1988) I showed that the value of the trade increased significantly between 1770 and 1785. The percentage of the market share of Irish exports to Great Britain in relation to exports to all parts remained, however, relatively steady, at about 77 percent.

Chapter Four produced a micro-history of the merchant communities in Dublin, Belfast and Liverpool. It focused on the facilitators of the mercantile and maritime interaction between Ireland and England, and discussed: the banking system and the creation of the Bank of Ireland; the merchants of Dublin, Belfast, and Liverpool and their trading activities; and the market concentration ratios of the two key commodities, butter and linen cloth. In Dublin, no merchant or group of merchants gained sufficient market power to exclude competitors in either the butter or linen cloth sectors. Similarly, in Liverpool the community of merchants were general traders rather than specialists.

This thesis has demonstrated the dramatic increase in merchant activities, exports and imports through the port of Dublin in the peacetime years from 1770 to 1785 . Data contained in Eaton's "List" demonstrate that a large number of small merchants fuelled this expansion. Comparison of the merchant communities in 1770 and 1785 reveal that some merchants or their kith and kin remained in their merchant houses. They were joined in all sectors of the market by myriad newcomers. This is also a reminder that the agricultural sector, with its low entry cost for merchants, along with the proto "industrial" linen sector, dominated the Irish economy. 


\section{Appendices}

Appendix I: Merchants from Eaton's "List" of exporters matched with entries in Wilson's Directory for Dublin, 1786 


\section{Appendix 1: Merchants from Eaton's "List" of exporters matched with entries in Wilson's Directory for Dublin, 1786.}

\begin{tabular}{|c|c|c|c|c|}
\hline Recorded Exporter & Name & Occupation & Address & Wholesale \\
\hline Eaton's "List" & Dublin Directory & Dublin Directory & Dublin Directory & Merchant \\
\hline & & & & yes or no \\
\hline Alcock, George & Alcock, George & Alderman & 6, George's-hill & yes \\
\hline Alexander, Wm. & Alexander, William (snr) & Merchant & 17, Mary's-abbey & yes \\
\hline Allan \& Black & Allan and Black & Porter-merchants & 10 , great Strand-street & no \\
\hline Alley \& Darby & Alley, William/Darby, Damer & Merchant/Merchant & 73, Fleet-street/6, Cope-street & no/ yes \\
\hline Anderson, Joseph & Anderson, Joseph & Wine-merchant & 36, Bachelors-walk & yes \\
\hline Andrews, Garrett & Andrews, Garret & Ship-broker & 44, Aston's-quay & \\
\hline Armstrong, Alexander & Armstrong, Alexander & Merchant & 16, Bow-lane & yes \\
\hline Armstrong, Francis \& Richard & Armstrong, Francis \& Richard & Merchants & 61, Bolton-street & no \\
\hline Armstrong, Wm. & not listed & & & \\
\hline Arnold, Wm. & Arnold, William & Silk-weaver & 50, Pill-lane & no \\
\hline Atkinson, John & Atkinson, John & Merchant & 25, Fleet-street & yes \\
\hline Badge, Thomas & Badge, Thomas & Tallow-chandler & 66, N. King-street & no \\
\hline Barcroft, Joseph & Barcroft, Joseph & Grocer & 51, Thomas-street & no \\
\hline Barry, Nath. & Berry, Nathaniel & Linen-draper & 34, Pill-lane & no \\
\hline Bates \& Gardiner & Bates and Gardiner & Merchants & 34, Fleet-street & yes \\
\hline Beeby, Wm. & Beeby, William & Merchant & 9, George's-street & no \\
\hline Berkett, Wm. & Birkett, William & Chandler, and soap-boiler & 34, Jervis-street & no \\
\hline Blake, John & Blake, John & Merchant & 37, Arran-quay & yes \\
\hline Boor, David & not listed & & & \\
\hline Bracken, James & Bracken, James & Merchant & Rainsford-street & no \\
\hline Bullin, John & not listed & & & \\
\hline Burgess, Francis & not listed & & & \\
\hline Burton, Robert & Burton, Robert & Merchant & 5, E. Liffey-street & no \\
\hline Byrne, Edward & Byrne, Edward & Merchant and Sugar-baker & Allen's court & yes \\
\hline Calbeck, Wm. Eaton & Calbeck, William Eaton & Merchant & 6, Bishop-street & no \\
\hline Callaghan, Denis & Callaghan, Dennis & Furrier & 22, Eustace-street & no \\
\hline Campbell, George & Campbell, George & Merchant & 15, Mary's-abbey & yes \\
\hline Cardiff, Mathew & ? Cardiff and Kehoe & Ship-wrights & 59, George's-quay & no \\
\hline Conolly, James & Connolly, James & Merchant & 83 , Fleet-street & yes \\
\hline Conolly, Roger & not listed & & & \\
\hline Cooney, John & Cooney, John & Merchant & 30, Poolbeg-street & no \\
\hline Corbett, Thomas & ? Corfield, Thomas & Merchant & 13, Bachelor's-walk & yes \\
\hline Corles, Thomas & Corles, Thomas & Merchant & 23, Watling-street & no \\
\hline Cowan, John & Cowan, John & Merchant & 58, Bolton-street & yes \\
\hline Crothers, Hugh & Crothers, Hugh & Sheriffs-peer and Merchant & 7, Lurgan-str[eet] & yes \\
\hline Crothers, M. & Crothers, Montgomery & Ship-broker & 6, Linen-hall-street & no \\
\hline Culloden, Michael & Cullidon, Michael & Butcher & 47, Patrick-street & no \\
\hline Darby, John & not listed & & & \\
\hline
\end{tabular}




\begin{tabular}{|c|c|c|c|c|}
\hline Recorded Exporter & Name & Occupation & Address & Wholesale \\
\hline Eaton's "List" & Dublin Directory & Dublin Directory & Dublin Directory & Merchant \\
\hline & & & & yes or no \\
\hline D'Arcy, Thames & Darcy, Thomas & Merchant & 22, N.[orth] Anne-street & no \\
\hline Darragh, John & not listed & & & \\
\hline Dickinson, Joseph, Wm., \& Dan. & Dickson, Jos. Will. and Daniel & Merchants & 10, Usher's-qu[ay] & yes \\
\hline Dodd, R. \& M. & Dodd, Rich. \& Mich. & Dry-coopers \& Merchants & 5, Bow-1[ane] & no \\
\hline Duncan, Wm. & Duncan, William & Merchant & 22, Beresford-street & no \\
\hline Dunn \& Co. & not listed & & & \\
\hline Dunn, Hinck \& O'Brien & Dunn, Hincks \& O'Brien & Ship-brok. Offi. & 3, Lisburn-st \& Cust-h-q & no \\
\hline Dunn, Wm. Bruce & Dunn, William-Bruce & Merchant & 4, Hendrick-street & yes \\
\hline Ellerton, John & Ellerton, John & Grocer & 5, George's-street & yes \\
\hline English, Matthew & English, Matthew & Toyman & 103, Grafton-street & no \\
\hline Forbes, Edward & Forbes, Edward & Merchant & 24, Bachelors-walk & yes \\
\hline Frood, James & Frood, James \& Co. & Merchants & 25, N.[orth] Anne-street & yes \\
\hline Galloway \& Stillas & Galloway and Stillas & Merchants & 16, Patrick-street & yes \\
\hline Geale, Ebnr., Fred., \& Dan. & Geale, Eb., Fred., and Dan. & Merchants & 7, Bachelors-walk & yes \\
\hline Gemmell \& Smith & Gemmell and Smith & Scotch-merchants & 32, Merchants-quay & no \\
\hline Gillis, Adam & not listed & & & \\
\hline Goff, Joseph & Goff, Joseph & Merchant & 93, Bride-street & no \\
\hline Gould, Wm. \& Nathaniel & not listed & & & \\
\hline Hall, Thomas & not listed & & & \\
\hline Ham, M. \& P. & Ham, Paul & Glover & 45, Pill-lane & no \\
\hline Hamill, John & Hamill, John & Merchant & 34, Beresford-street & no \\
\hline Harrison, Wm. & not listed & & & \\
\hline Hart, Edward & Hart, Edward & Merchant & Watling-street & no \\
\hline Hawksley \& Rutherford & Hawkesley and Rutherford & Merch. & 22, low, Ormond-quay & no \\
\hline Henshall, James & Henshall, James & Merchant & 3, Brown Linen-hall & no \\
\hline Hodgson, Thomas & not listed & & & \\
\hline Holmes Wm. & not listed & & & \\
\hline Holmes, Hugh & Holmes, Hugh & Merchant & 19, Queen-street & yes \\
\hline Howard, Peter & Howard, Peter & Dry-cooper & 6, Smock-alley & no \\
\hline Hugh Hamill \& Co. & Hamill, Hugh & Merchant & 20, N.[orth] Anne-street & no \\
\hline Hughes, Alexander & Hughes, Alexander & Merchant & 101, Capel-street & yes \\
\hline J. W. \& D. Dickinson & \begin{tabular}{|l|}
$\begin{array}{l}\text { Dickinson, Jos., Will. and } \\
\text { Daniel }\end{array}$ \\
\end{tabular} & Merchants & 10, Usher's-qu[ay] & yes \\
\hline Jaffray \& Co. & Jaffray, Fayle, and Hautenville & Merchants & 19, Eustace-str.[eet] & no \\
\hline John James Pache Co. & Pache, John James and Co. & Merchants & 26, Usher's-quay & no \\
\hline Kenny, Thomas & Kenny, Thomas & Merchant & 13, lit.[tle] Britain-street & no \\
\hline Kiernan, Francis & not listed & & & \\
\hline Kirchner, John Simon & Kirchner, John Simon & Furrier & 17, gt.[great] Britain-street & no \\
\hline Lane, James & Lane, James & Sheriffs Peer \& Dry cooper & 23, Anglesea-str.[eet] & yes \\
\hline Laurence, Sam. & Lawrence, Samuel & Dry-cooper & 123, Abbey-street & no \\
\hline Lecky \& Wilson & Lecky and Wilson & Merchants & 8, low, Ormond-quay & yes \\
\hline Leear, George & Lear, George & Merchant & 3, Gloucester-street & yes \\
\hline
\end{tabular}




\begin{tabular}{|c|c|c|c|c|}
\hline Recorded Exporter & Name & Occupation & Address & Wholesale \\
\hline \multirow[t]{2}{*}{ Eaton's "List" } & Dublin Directory & Dublin Directory & Dublin Directory & Merchant \\
\hline & & & & yes or no \\
\hline Lindsey, John & Lindsay, John & Merchant & 10, Jervis-street & yes \\
\hline Maguire, Ross & Maguire, Ross & Merchant & 34, Arran-quay & no \\
\hline Malben, John & Maibin, John & Merchant & 64, Pill-lane & no \\
\hline Malkin, Robert & not listed & & & \\
\hline Marks, Simon & & ships-captain & & no \\
\hline McCarty, Michael & Mc. Carty, Michael & Merchant & 27, George's-quay & yes \\
\hline \multirow[t]{2}{*}{ McCormick, Pat } & Mc. Cormick, Patrick & Skinner or & 6, Watling-street & no \\
\hline & Mc. Cormick, P. & Skinner \& Feather-merch. & 63, Dirty-lane & no \\
\hline McCowan, James & Mc. Cowan, James & Ship-broker & 1, Crampton-quay & no \\
\hline McDermott, Anthony & Mc. Dermott, Anthony & Merchant & 30, Arran-quay & yes \\
\hline McDonald, James & not listed & & & \\
\hline McGuire \& Robinson & not listed & & & \\
\hline McLoghlan, John & Mc. Loghlin, John & Merchant & 18, Usher's-quay & yes \\
\hline McQuillan, John & not listed & & & \\
\hline Melvill, David & Melvill, David & Merchant & 36, Bow-street & yes \\
\hline Mercer, Robert \& Richard & Mercer, Robert and Richard & Merchants & 52, Capel-street & no \\
\hline Mitchell \& Anderson & Mitchell and Anderson & Merchants & 21, Abbey-street & yes \\
\hline Newport, Mathew & Newport, Matthew & Merchant & 48, Golden-lane & no \\
\hline \multirow[t]{2}{*}{ Nowlan, Thomas } & Nowlan, Thomas or & Baker & 12 , Bride-street & no \\
\hline & Nowlan, Thomas & Sugar-baker & 110, Francis-street & no \\
\hline O'Brien \& Comerford & O'Brien and Comerford & Merchants & 19, Merchants-quay & no \\
\hline O'Connor, Val. \& Malachy & O'Connor, Val. and Malachy & Merchants & 16, Bachelors-walk & yes \\
\hline Oldham, Thomas & Ouldham, Thomas & Merchant & 94, N. [orth] King-street & no \\
\hline Orr, John & ? Orr, William and John & Scots-merchants & 8, Merchants-quay & no \\
\hline Orr, John \& Thomas & ? Orr, Thomas & Linen-draper & 50, Henry-street & no \\
\hline Overend, George & Overend, George & Merchant & 6, Lurgan-street & no \\
\hline Oxley \& Hague & Oxley and Hague & Woollen-factors & 51, Fishamble-street & yes \\
\hline Palmer, Henry & not listed & & & \\
\hline Patrick \& Co. & Patrick and Co. & Merchant & 17, Abbey-street & yes \\
\hline Phelps, Willcocks \& John & Phelps, Wilcocks and John & Merchants & 28, Mary's-abbey & yes \\
\hline Pim, Joshua & Pim, Joshua & Merchant & 15, Usher's-island & yes \\
\hline Power, Richard & not listed & & & \\
\hline Quincey, Thomas & not listed & & & \\
\hline Ramadge, Smith & Ramadge, Smith & Merchant & 9, Granby-row & no \\
\hline Rathbone, Wm. & Rathborne, William & Wax-chandler & 47, Essex-street & yes \\
\hline Reilly, James & Reily, James & Merchant & 22, Thomas-street & no \\
\hline Roach, John & ? Roche, John & Merchant & 7, William-street & no \\
\hline Robinson \& Co. & ? Robinson, Sandwith \& Co & Merchants & 42, Aston's-quay & no \\
\hline Robinson, Wm. & Robinson, William & Merchant & 56, City-quay & no \\
\hline Roche, John & Roche, John & Merchant & 7, William-street & no \\
\hline Rohe, John & ? Roche, John & & & \\
\hline Sevill, George & not listed & & & \\
\hline
\end{tabular}




\begin{tabular}{|c|c|c|c|c|}
\hline Recorded Exporter & Name & Occupation & Address & Wholesale \\
\hline Eaton's "List" & Dublin Directory & Dublin Directory & Dublin Directory & Merchant \\
\hline & & & & yes or no \\
\hline Sheil, James & Sheil, James, Rt. Hon. & Lord-mayor & Dawson-street & no \\
\hline Sims, Wm. & not listed & & & \\
\hline Stephens, John & not listed & & & \\
\hline Stephens, Sam. & Stephens, Samuel & Grocer & 30, Bishop-street & yes \\
\hline Stewart, Donald & Stewart, John and Donald & Merchants & 10, Aston's-quay & no \\
\hline Strettle, Amos & Strettle, Amos & Merchant & 9, Merrion-square & yes \\
\hline Sweeney, Michael & Sweeny, Michael & Merchant & Mill-street & no \\
\hline T \& J Nicholson & Nicholson, Thomas and John & Linen-drapers & 10, Bride-street & yes \\
\hline T. Mitchell \& J. Anderson & Mitchell and Anderson & Merchants & 21, Abbey-street & yes \\
\hline Tiernan, John \& Thomas & ? Tiernan, John & Florist & 26, Camden-street & no \\
\hline Totty, Henry & not listed & & & \\
\hline Tourtellott, Lewis \& Peter & $\begin{array}{l}\text { Tourtellot, Lewis / } \\
\text { Peter Joseph }\end{array}$ & Merchant / merchant & $\begin{array}{l}\text { 72, Fleet-street / } \\
\text { 140, Abbey-street }\end{array}$ & yes \\
\hline Walker, Robert & Walker, Robert & Timber-merchant & 5, Engine-alley & no \\
\hline Walsh, P. \& T. & ? Walsh, Patrick & Printer & 19, Coal-quay & no \\
\hline Weld, Isaac & Weld, Isaac & Merchant & 12, low, Abbey-street & yes \\
\hline Westray, Henry & Westray, Henry & Tanner & 57, James's-street & no \\
\hline Wilkinson, Abraham & Wilkinson, Abraham and Peter & Merchants & 4, W.[est] Park-street & yes \\
\hline Wilson, Joshua \& Ben. & Wilson, Joshua and Benjamin & Merchants & 48, Golden-lane & no \\
\hline Wm., Wm. & ? Williams, William & Coach-maker & 130, Britain-street & no \\
\hline Wood, Bacon \& Co. & not listed & & & \\
\hline Young, John & Young, John & Taylor & 19, up.[per] Stafford-street & no \\
\hline
\end{tabular}




\section{Bibliography:}

\section{PRIMARY SOURCES - HELD IN OVERSEAS REPOSITORIES:}

\section{Public Record Office of Northern Ireland [PRONI], Belfast:}

$\mathrm{D} / 207$

$/ 31 / 1$

$/ 31 / 6$

$/ 31 / 22$

$\mathrm{T} / 1715 / 1$

$\mathrm{MIC} / 511$
Trade - External

Statistics re Irish trade, 1778-1826.

Prices in London, Liverpool, England and Wales, 17901803.

Trade statistics.

Abstracts of Irish Imports and Exports.

Trade-External

Irish Customs \& revenues statistics, 1760-1810.

Trade statistics, 1778-1826.

Dublin City Archives (Gilbert Collection):

Eaton, Richard

A Daily and Alphabetical Arrangement of all Imports and Exports at the Port of Dublin, in the Quarter ending the $25^{\text {th }}$ March, 1785, Dublin, 1786.

Walker's Hibernian Magazine, Vol. XVI, July 1789, Dublin.

Wilson's Dublin Directory for the year [1752 ongoing], containing an alphabetical list of the merchants, traders, judges, barristers, attornies, solicitors, advocates, proctors, public-notaries, physicians, surgeons, etc. and a new list of the nobility and gentry, their town and country residences, etc., etc., to which is annexed a new plan of Dublin and a list of streets which mutually explain and illustrate each other.

\section{Liverpool Record Office, Liverpool}

Bailey's Western and Midland Directory, 1783 [a typed extract of all entries relevant to Liverpool, taken from the master volume]

The Tradesman: or Commercial Magazine, No. 31, Vol. 6, London, January 1811.

Enfield, William

An Essay Towards the History of Liverpool: Drawn up from papers left by the late Mr George Perry, and from other materials since collected, London, 1774.

Maguire, Phillip James

Liverpool Trade List: published weekly from the Custom House books, No. 451, $8^{\text {th }}-14^{\text {th }}$ December 1802.

\section{Liverpool Hope University, Sheppard-Worlock Library}

Touzeau, James

The Rise and Progress of Liverpool from 1551 to 1835, (2 volumes), Liverpool, 1910. 
Media: Microfilm:

National Library of Australia

The Belfast News-Letter

Ref: $\mathrm{mfm}$ X1043

Reel $1770 \quad 1770$ issues

Reel $1785 \quad 1785$ issues

The Freeman's Journal, [Dublin]; Ref: mfm X278

$\begin{array}{ll}\text { Reel } 4 & \text { 1 Apr } 1769 \text { to } 18 \text { Sep } 1770 \\ \text { Reel } 5 & \text { 15 Sep } 1770 \text { to } 29 \text { Aug } 1771 \\ \text { Reel } 16 & \text { 7 Oct } 1785 \text { to } 1 \text { Feb } 1785 \\ \text { Reel } 17 & \text { 1 Feb } 1785 \text { to } 26 \text { May } 1786\end{array}$

University of Nebraska, Lincoln

Naval Office Supply Lists for the West Indies, 1678-1825; Ref: MFILM/B/2000

97058/1 includes: Antigua $1785 \quad$ (PRO ref CO10/2 applies)

Bahamas $1785 \quad$ (PRO ref CO27/14 applies)

97058/7 includes: $\quad$ Barbados $1785 \quad$ (PRO ref CO33/19 applies)

Barbados $1800 \quad$ (PRO ref CO33/21 applies)

97058/9 includes: Dominica 1800 (PRO ref CO76/5 applies)

97058/10 includes: Grenada (Ports of Saint George \& Grenville) 1785 PRO ref CO106/4 applies)

97058/12 includes: St Kitts $1785 \quad$ (PRO ref CO243/1 applies)

97058/13 includes: Tobago $1800 \quad$ (PRO ref CO290/1 applies)

Tortola $1785 \quad$ (PRO ref CO317/1 applies)

University of Rochester, New York

Papers of William Davenport \& Co., 1745-1797; Ref: DocMicro FILM 2003.5/

Reel $1 \quad$ Trading Invoices and Accounts, 1761-1773

Reel 2 Trading Invoices and Accounts, 1772-1785

Reel 3 Trading Invoices and Accounts, 1785-1797 


\section{PRIMARY SOURCES - HELD IN NEW ZEALAND REPOSITORIES}

\section{Media: Microfilm:}

Victoria University of Wellington

Manchester Mercury and Harrop's General Advertiser; Ref: Micp100

Reel 1768-1770

1770 issues

Reel 1784-1786

1785 issues

Private Collection: Dr Stephen D. Behrendt

Liverpool General Advertiser

Reel covering 17 Nov 1769 - 5 May $1775 \quad 1770$ issues

Reel covering 11 Nov $1784-27$ Dec $1787 \quad 1785$ issues

\section{Media: Microfiche:}

Private Collection: Dr Stephen D. Behrendt

Lloyd's Register of British \& Foreign Shipping, 1776-1880

Fiche $1786 \quad$ covering vessels surveyed in 1785

Fiche $1801 \quad$ covering vessels surveyed in 1800 


\section{ELECTRONIC DATABASES AND SOURCES:}

Eighteenth Century Collections Online (URL:

http//galenet.galegroup.com/servlet/ECCO)

"Dublin Society" Transactions of the Dublin Society, Vols. 1-6, Dublin, 1800.

Eaton, Richard

The Book of Rates, Inwards and Outwards: with the neat duties and drawbacks payable on importation and exportation of all sorts of merchandize, Dublin, 1765.

Laffan, James

A Political Arithmetic of the Population, Commerce and Manufactures with Observations on the relative Situation of Great Britain and Ireland, Dublin, 1785.

Macartney, George

Nevill, John

Reeves, John

"Society for the Registry of Shipping (London, England)"

"Society of Merchants, Ship-Owners, and Under-writers"

Whitworth, Sir Charles

Young, Arthur
An account of Ireland in 1773. By a late chief secretary of that Kingdom, London, 1773.

Seasonable Remarks on the Linen-Trade of Ireland, with some observations on the present state of that country, Dublin, 1783.

A history of the law of shipping and navigation, London, 1792.

Register of Ships, No. 4, Sun Court, Corn Hill, 1792, [London], [1791].

The new register book of shipping, for the year 1800, London, [1800].

State of the Trade of Great Britain in its Imports and Exports, progressively from the year 1697: Also of the Trade to each particular Country, during the above Period, distinguishing each Year, London, 1776.

A Tour in Ireland: with general observations on the present state of that kingdom: made in the years 1776, 1777, and 1778. And brought down to the end of 1779. 2 Volumes, London, 1780.

in William F. Mavor (comp), The British Tourists: or Traveller's Pocket Companion, Through England, Wales, Scotland, and Ireland. Comprehending the most celebrated tours in the British Islands, Vols. 1-6, pp. 153-212, (Vol. 3), London, 1798-1800.

The Belfast Almanack, (improved and enlarged) for the year of our Lord 1773, Belfast, 1773. 
The Belfast Town and Country Almanack, for the year 1796, [Belfast], [1796].

The new Birmingham directory, and gentleman and tradesman's compleat memorandum book: containing a brief description of the town of Birmingham. London, [1774?].

Gore's Liverpool Directory, for the year 1777; containing an alphabetical list of the merchants, tradesmen, and principal inhabitants of the town of Liverpool; with the numbers as they are affixed to their houses..., Liverpool, 1777.

Gore's Liverpool Directory, or alphabetical list of the merchants, tradesmen, and principal inhabitants of the town of Liverpool; with the numbers as they are (or ought to be) affixed to their houses..., Liverpool, 1790.

Schofield's New Liverpool Directory or An Alphabetical List of the Merchants, Tradesmen, etc of the Town of Liverpool, Liverpool, 1800.

The New Jamaica almanack, and register, calculated to the median of the island for the year of our Lord 1801...Jamaica, 1800.

Oxford Dictionary of National Biography: (URL: http://www.oxforddnb.com) Brogan, Hugh 'Clarkson, Thomas 1760-1846' Oxford Dictionary of National Biography, Oxford, 2004;

URL: http://www.oxforddnb.com/view/article/5545, accessed 25 May 2005.

Davis, Peter

'Backhouse family per. c.1770-1945' Oxford Dictionary of National Biography, Oxford, 2004;

URL: http://www.oxforddnb.com/view/article/56500, accessed 25 May 2005.

Dickson, P. G. M.

'Barclay, David 1682-1769' Oxford Dictionary of National Biography, Oxford, 2004;

URL: http://www.oxforddnb.com/view/article/37149, accessed 25 May 2005.

Fenwick, Simon

'Nicholson, Francis 1753-1844' Oxford Dictionary of National Biography, Oxford, 2004;

URL: http://www.oxforddnb.com/view/article/20132, accessed 25 May 2005.

Fyfe, Christopher

'Lloyd, Charles 1748-1828' Oxford Dictionary of National Biography, Oxford, 2004;

URL: http://www.oxforddnb.com/view/article/16821, accessed 25 May 2005.

Gordon, Alexander

'Rathbone, William 1757-1809' rev. M W Kirby, Oxford Dictionary of National Biography, Oxford, 2004;

URL: http://www.oxforddnb.com/view/article/23160, 
Pollard, A. F.

Price, Jacob M.

Spence, Joseph

Swan, H. T.

Trinder, Barrie

Wilkes, Joanne accessed 25 May 2005.

'Froude, James Anthony (1818-1894), rev. William Thomas, Oxford Dictionary of National Biography, Oxford, 2004;

URL: http://www.oxforddnb.com/view/article/10202, accessed 26 October 2005.

'Barclay, David 1729-1809' rev. Leslie Hannah, Oxford Dictionary of National Biography, Oxford, 2004;

URL: http://www.oxforddnb.com/view/article/37150, accessed 25 May 2005.

'Lecky, (William) Edward Hartpole (1838-1903), Oxford Dictionary of National Biography, Oxford, 2004

URL: http://www.oxforddnb.com/view/article/34461, accessed 26 October, 2005.

'Overend, Hall 1772-1831' Oxford Dictionary of National Biography, Oxford, 2004;

URL: http://www.oxforddnb.com/view/article/68312, accessed 25 May 2005.

'Reynolds, Richard 1735-1816 Oxford Dictionary of National Biography, Oxford, 2004;

URL: http://www.oxforddnb.com/view/article/23433, accessed 25 May 2005.

'Reynolds, William 1758-1803' Oxford Dictionary of National Biography, Oxford, 2004;

URL: http://www.oxforddnb.com/view/article/23445, accessed 25 May 2005.

'Rathbone (nee Reynolds), Hannah Mary 1798-1878' Oxford Dictionary of National Biography, Oxford, 2004; URL: http://www.oxforddnb.com/view/article/23158, accessed 29 May 2005. 


\section{PUBLICATIONS:}

\section{$\underline{18^{\text {th }} \text { Century: }}$}

\section{9 ${ }^{\text {th }}$ Century:}

Bennett, William

Brooke, Richard

Froude, James A.

Hume-Williams, W. Ellis

Hutton, A. W. (ed.)

Jevons, William S.

Lecky, W. E. H.

MacPherson, David

Pim, Jonathan

Rathbone, H. M.

Wakefield, Edward
New Lloyd's List, London, 1770, (republished in a bound volume along with the 1769 lists), Hants., England, 1969.

New Lloyd's List, London, 1785, (republished in a bound volume along with the 1786 lists), Hants., England, 1969.

Narrative of a Recent Journey of Six Weeks in Ireland in connexion with the subject of supplying small seed to some..., Dublin, 1848. [sighted Queens University, Belfast, Library Special Collections].

Liverpool as it was [during the Last Quarter of the Eighteenth Century,]: 1775-1800, Liverpool, 1853 (revised edition, 2003).

The English in Ireland in the Eighteenth Century, London, 1872.

The Irish Parliament from the Year 1782 to 1800, London, 1879, pp. 98-99.

Young's Tour in Ireland, London, 1892.

The Coal Question: An Inquiry Concerning the Progress of the Nation, and the Probable Exhaustion of our Coal-mines, London, 1865 ( $2^{\text {nd }}$ edition, 1866, revised).

A History of Ireland in the Eighteenth Century, London, 1887.

Annals of Commerce, London, 1805.

Conditions and Prospects in Ireland..., Dublin, 1848. [sighted Queens University, Belfast, Library Special Collections].

Letters of Richard Reynolds, with a memoir of his life, London, 1852.

An Account of Ireland, Statistical and Political, (2 vols.) London, 1812. 
Young, Robert M. (ed.)

20 $0^{\text {th }}$ Century (Pre-1950)

Barclay, Hubert F. and Alice Wilson-Fox

Clark, G. N.

Emden, Paul H.

Gill, Conrad

Gregg, E.

Grubb, Isabel

Lowry, Mary

Murray, Alice E.

O’Brien, George

O’Brien, George (ed.)

Wagner, Henry R.

Secondary Sources:

Adams, J. R. R.

Agnew, Jean
The Town Book of Belfast, 1613-1816: edited from the original with chronological list of events and notes..., Belfast, 1892. [sighted Belfast Central Library, Local History room]

A History of the Barclay Family, with Pedigrees from 1067 to 1933: Part III - The Barclays in Scotland and England from 1610 to 1933, London, 1934.

Guide to English Commercial Statistics, 1696-1782, London, 1938.

Quakers in Commerce: A Record of Business Achievement, London, 1939.

The Rise of the Irish Linen Industry, London, 1925 (reprinted 1964).

Reynolds and Rathbone Diaries and Letters, 1753-1839, London, 1905. [sighted Queens University, Belfast, Library Special Collections].

Quakerism and Industry Before 1800, London, 1930.

The Story of Belfast and its Surroundings, London, 1913.

A History of the Commercial Relations between England and Ireland from the period of the Restoration, London, 1903 (reprinted New York, 1970).

The Economic History of Ireland in the Eighteenth Century, Dublin, 1918 (reprinted Philadelphia, 1977).

The Bank of Ireland, 1783-1946, Dublin 1949.

Irish Economics 1700-1783: A bibliography with notes, London, 1907.

Merchants in Plenty: Joseph Smyth's Belfast Diary 1807/8, Belfast, 1991.

The Merchant Community of Belfast, 1660-1707, Belfast, 1994.

Belfast Merchant Families in the Seventeenth Century, Belfast, 1996. 
Bardon, Jonathan

Boylan, Henry

Burton, Valerie (ed.)

Cochran, L. E.

Collins, Brenda and Philip Ollerenshaw

Connell, K. H.

Craig, Maurice

Crawford, W. H.

Cullen, L. M.

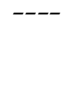

Cullen, L. M. and

T. C. Smout (eds.)

Devine, Tom

Devine, T. M. and

David Dickson

Doerflinger, Thomas M.
Belfast: An Illustrated History, Dundonald, 1982.

Dictionary of Irish Biography, (2 $2^{\text {nd }}$ edition Dublin, 1988).

Liverpool Shipping, Trade \& Industry, Liverpool, 1989.

Scottish Trade with Ireland in the Eighteenth Century, Edinburgh, 1985.

'The European Linen Industry since the Middle Ages', in Brenda Collins and Philip Ollerenshaw (eds.), The European Linen Industry in Historical Perspective, Oxford, 2003.

The Population of Ireland, 1750-1845, London, 1950.

Dublin, 1660-1860: a social and architectural history, Suffolk, 1952 (reprinted 1980).

The impact of the Domestic Linen Industry in Ulster, Belfast, 2005.

Anglo-Irish Trade, 1660-1800, Manchester, 1968.

The Emergence of Modern Ireland, 1600-1900, London, 1981.

'Landlords, Bankers and Merchants: The Early Irish Banking World, 1700-1820', in Antoin E. Murphy (ed.) Economists and the Irish Economy from the Eighteenth Century to the Present Day, Dublin, 1984.

Economic History of Ireland since 1660, London, 1972, (2 $2^{\text {nd }}$ edition, 1987).

Comparative Aspects of Scottish and Irish Economic and Social History, 1600-1900, Edinburgh, 1977.

The Tobacco Lords: A study of the tobacco merchants of Glasgow and their trading activities c.1740-1790, Edinburgh, 1990.

Ireland and Scotland, 1600-1850: Parallels and Contrasts in Economic and Social Development, Edinburgh, 1983.

A Vigorous Spirit of Enterprise: Merchants and Economic Development in Revolutionary Philadelphia, Chapel Hill (North Carolina), 1986. 
Eames, Aled

Edwards, Ruth D.

Findlater, Alex

Foster, R.F. (ed.)

Gilligan, Henry A.

Harrison, Richard

Hood, Adrienne D.

Hoskins, Colin, Stuart

McFadyen, and Adam Finn

Hyde, Francis E.

Hyland, Peter

James, Francis G.

Johnston, Edith M.

Jones, Emrys
'Liverpool and North Wales: Seafarers and Shipping Entrepreneurs' in Valerie Burton (ed.), Liverpool Shipping, Trade and Industry: Essays on the Maritime History of Merseyside, 1780-1860, Liverpool, 1989.

An Atlas of Irish History, London, 1973 ( $2^{\text {nd }}$ edition, New York, 1981).

Findlaters: the story of a Dublin Merchant Family, 1774-2001, Dublin, 2001. [sighted Trinity College, Dublin, Library].

The Oxford Illustrated History of Ireland, Oxford, 1989.

A History of the Port of Dublin, Dublin, 1989.

A Biographical Dictionary of Irish Quakers, Dublin, 1997. [sighted Belfast Central Library, Local History room].

'Flax Seed, Fibre and Cloth: Pennsylvania's Domestic Linen Manufacture and its Irish Connection, 1700-1830', in Brenda Collins and Philip Ollerenshaw (eds.), The European Linen Industry in Historical Perspective, Oxford, 2003.

Media Economics: Applying Economics to New and Traditional Media, Thousand Oaks, Calif., 2004.

Liverpool and the Mersey: An Economic History of a Port, 1700-1970, Devon, 1971.

The Herculaneum Pottery: Liverpool's Forgotten Glory, Liverpool, 2005.

Ireland in the Empire, 1688-1770: A History of Ireland from the Williamite Wars to the Eve of the American Revolution, Cambridge, Mass., 1973.

Great Britain and Ireland, 1760-1800: a study in political administration, London, 1963.

Irish History: a select bibliography, London, 1969.

Ireland in the eighteenth century, Dublin, 1974.

A Social Geography of Belfast, London, 1960. 
Lemire, Beverly

Lynch, Patrick and John Vaizey

MacLysaght, Edward McCusker, John J.

McDowell, R.B.

Martin, Sheila

Mitchell, B.R. with

Phyllis Deane

Mitchison, Rosalind

Mui, Hoh-cheung and Lorna $\mathrm{H}$.

Nash, Gary

Nottingham, Lucie

O'Grada, Cormac

O’Hearn, Denis

Ó Tuathaigh, Gearóid

Price, Jacob M.

Public Record Office of Northern Ireland (PRONI)
'Transforming consumer Custom: Linen, Cotton, and the English Market, 1660-1800' in Brenda Collins and Philip Ollerenshaw (eds), The European Linen Industry in Historical Perspective, Oxford, 2003.

Guiness's Brewery in the Irish Economy, 1759-1876, Cambridge, 1960.

More Irish Families, Dublin, 1960.

Money and Exchange in Europe and America, 1600-1775: A Handbook, Virginia, 1978.

Ireland in the Age of Imperialism and Revolution, 1760-1801, Oxford, 1979.

Directory of Merchants and Traders of Dublin in 1798, Dublin, 2000. [sighted Trinity College, Dublin, Library].

Abstract of British Historical Statistics, London, 1962.

A History of Scotland, London, 1970 (second edition, 1982).

Shops and Shopkeeping in Eighteenth century England, London, 1987.

'The Early Merchants of Philadelphia: The Formation and Disintegration of a Founding Elite', in Richard S. Dunn \& Mary Maples Dunn (eds.), The World of William Penn, Philadelphia, 1986, pp. 337-362.

Rathbone Brothers: From Merchant to Banker, 1742-1992, London, 1992.

Ireland: A New Economic History, 1780-1939, Oxford, 1994.

The Atlantic Economy: Britain, the United States and Ireland, Manchester, 2001.

Ireland Before the Famine, 1798-1848, Dublin, 1972.

'The Great Quaker Business Families of EighteenthCentury London: The Rise and Fall of a Sectarian Patriciate', in Richard S. Dunn \& Mary Maples Dunn (eds.), The World of William Penn, Philadelphia, 1986, pp. 363-400.

Aspects of Irish Social history, 1750-1800, Belfast, 1969 (reprinted 1984). 
Raistrick, Arthur

Ritchie-Noakes, Nancy and Mike Clarke

Ryan, Christopher

Schumpeter, Elizabeth B.

Smyth, William J. and

Kevin Whelan (eds.)

Somerville-Large, Peter

Thomas, Brinley

Truxes, Thomas M.

Windsor, David Burns

Zupko, Ronald E.
Quakers in Science and Industry, Devon, 1950 (revised 1968).

'The Dock Engineer and the Development of the Port of Liverpool', in Valerie Burton (ed.), Liverpool Shipping, Trade and Industry: Essays on the Maritime History of Merseyside, 1780-1860, Liverpool, 1989.

Lewis' Dublin: Topographical Dictionary of the Parishes, Towns and Villages of Dublin City and County, Cork, 2001.

English Overseas Trade Statistics, 1697-1808, Oxford, 1960.

Common Ground: Essays on the Historical Geography of Ireland - Presented to T. Jones Hughes, Cork, 1988.

Dublin: The First Thousand Years, Belfast, 1987.

'Food Supply in the United Kingdom during the Industrial Revolution' in Joel Mokyr (ed.), The Economics of the Industrial Revolution, London, 1985.

Irish-American Trade, 1660-1783, Cambridge, 1988.

Letterbook of Greg \& Cunningham, 1756-1757: Merchants of New York and Belfast, Oxford, 2001.

The Quaker Enterprise: Friends in Business, London, 1980.

A dictionary of English weights and measures; from AngloSaxon times to the nineteenth century, Wisconsin, 1968.

British weights \& measures: a history from antiquity to the seventeenth century, Wisconsin, 1977. 


\section{JOURNAL ARTICLES:}

$19^{\text {th }}$ Century

Kiaer, Anders N.

20 $0^{\text {th }}$ Century (Pre-1950)

Beachem, A.

Bell, Herbert C.

Connell, K. H.

Gras, N. S. B.

Hammond, Joseph W.

Hamilton, Earl J.

Jacob, W. J.

O’Brien, George

O'Connor, Theresa M.

Prendeville, P.L.
'The Shipping Trade between the United States and the United Kingdom', Journal of Political Economy, Vol. 5, no. 1, December 1896, pp.1-22.

'The Ulster Linen Industry', Economica, (New Series), Vol. 11, no. 44, November 1944, pp.199-209.

'British Commercial Policy in the West Indies, 1783-93', English Historical Review, Vol. 31, no. 123, July 1916, pp.429-41.

'The Population of Ireland in the Eighteenth Century', Economic History Review, Vol. 16, no. 2, 1946, pp.111-24.

'Land and Population in Ireland, 1780-1845', Economic History Review, (New Series), Vol. 2, no. 3, 1950, pp.27889.

'The Origin of the National Customs-Revenue of England', Quarterly Journal of Economics, Vol. 27, no. 1, November 1912, pp.107-49.

'George's Quay and Rogerson's Quay in the Eighteenth Century', Dublin Historical Record, Vol. 5, no. 2, December 1942-February 1943, pp.41-54.

'The Growth of Rigidity in Business during the Eighteenth Century', American Economic Review, Vol. 30, no. 1, pp.298-305.

'The Dublin Family of Jacob', Dublin Historical Record, Vol. 2, 1939-40, pp.134-40.

'The Irish Free Trade Agitation of 1779', English Historical Review, Vol. 38, no. 152, October 1923, pp.564-81.

'The Embargo on the Export of Irish Provisions, 1776-9', Irish Historical Studies, Vol. 2, 1940-1, pp.3-11.

‘Bibliography: A Select Bibliography of Irish Economic History, Part Two: The Seventeenth and Eighteenth Centuries', Economic History Review, Vol. 3, no. 3, April 1932, pp.402-16. 
Rees, Henry

Rees, J. F.

Sears, Louis M.

Tenison, C. MacCarthy

Usher, Abbott P.

20 $0^{\text {th }}$ Century (Post-1950)

Alpern, Stanley B.

Andrews, John $\mathrm{H}$.

Armstrong, John

Boyce, Gordon

Burns, Robert E

Butler, K

Cain, P. J. and

A. G. Hopkins,
'Evolution of Mersey Estuarine Settlements,' Economic Geography, Vol. 21, no. 2, April 1945, pp.97-103.

'The Phases of British Commercial Policy in the Eighteenth Century', Economica, no. 14, June 1925, pp.130-50.

'British Industry and the American Embargo', Quarterly Journal of Economics, Vol. 34, no. 1, November 1919, pp.88-113.

'Notes on Some Old Dublin Bankers', 'The Old Dublin Bankers' series of articles in Journal of the Institute of Bankers, Dublin, vols. 2-6, 1900-1904.

'The Old Provincial Private Bankers' series of articles in Journal of the Institute of Bankers, Dublin, vols. 6-12, 19041912.

'The Growth of English Shipping, 1572-1922', Quarterly Journal of Economics, Vol. 42, no. 3, May 1928, pp.465-78.

'What Africans Got for Their Slaves: A Master List of European Trade Goods', History in Africa, Vol. 22, 1995, pp.5-43.

'Anglo-American Trade in the Early Eighteenth Century', Geographical Review, Vol. 45, no. 1, January 1955, pp.99110.

'The Significance of Coastal Shipping in British Domestic Transport, 1550-1830', International Journal of Maritime History, Vol. 3, no. 2, December 1991, pp.63-94.

'Network knowledge and network routines: negotiating activities between shipowners and shipbuilders', Business History, Vol. 45, issue 2, April 2003, pp.52-79.

'The Catholic Relief Act in Ireland, 1778', Church History, Vol. 32, no. 2, June 1963, pp.181-206.

'Friends in Dublin', Dublin Historical Record, Vol. 44-5, 1991-2, pp.34-46.

'The Political Economy of British Expansion Overseas, 1750-1914', Economic History Review (New Series), Vol. 33, no. 4, November 1980, pp.463-90. 
Carrington, Selwyn H. H.

Chapman, Stanley D.

Checkland, S. G.

Clarkson, L. A.

Clemens, Paul G. E.

Craig, Robin

Crawford, W. H.

Cullen, L. M.

Darity, William Jr

Daultrey, Stuart,

David Dickson, and

Cormac O'Grada

Davis, Ralph

Deane, Phyllis
'The American Revolution and the British West Indies' Economy', Journal of Interdisciplinary History, Vol. 17, no. 4, Spring, 1987, pp.823-50.

'British Marketing Enterprise: The Changing Roles of Merchants, Manufacturers, and Financiers, 1700-1860', Business History Review, Vol. 53, no. 2, Summer 1979, pp.205-34.

'Economic Attitudes in Liverpool, 1793-1807', Economic History Review, (New Series), Vol. 5, no. 1, 1952, pp.58-75.

'The Writing of Irish Economic and Social History since 1968', Economic History Review (New Series), Vol. 33, no. 1, February 1980, pp.100-11

'The Rise of Liverpool, 1665-1750', Economic History Review, Vol. 29, no. 2, 1976, pp.211-24.

'Capital Formation in Shipping', Research in Maritime History, no. 24, 2003, pp.41-58.

'The Evolution of the Linen trade in Ulster before Industrialization', Irish Economic and Social History, Vol. 15, 1988, pp.32-53.

'The Exchange Business of the Irish Banks in the Eighteenth Century', Economica, (New Series), Vol. 25, no. 100, November 1958, pp.326-38.

'The Value of Contemporary Printed Sources for Irish Economic History in the Eighteenth Century', Irish Historical Studies, Vol. 14, 1964-5, pp.142-55.

'British Industry and the West Indies Plantations', Social Science History, Vol. 14, no. 1, Spring 1990, pp.117-49.

'Eighteenth Century Irish Population: New Perspectives from Old Sources', Journal of Economic History, Vol. 41, no. 3, September 1981, pp.601-28.

'English Foreign Trade, 1700-1774', Economic History Review (New Series), Vol. 15, no. 2, 1962, pp.285-303.

'The Output of the British Woolen Industry in the Eighteenth Century', Journal of Economic History, Vol. 17, no. 2, June 1957, pp.207-23. 
Devine, Tom

Esteban, Javier C.

Fairlie, Susan

Farnie, D. A.

Flood, Donal T.

French, Christopher J.

Habakkuk, H. J.

Haggerty, Sheryllynne

Hamilton, Bernice

Houston, Robert A.

Hughes, J. L. J. Kent Eriksson and Jan Johanson

Hoppitt, Julian
The Tobacco Lords: A study of the tobacco merchants of Glasgow and their trading activities, c.1740-1790, Edinburgh, 1990.

'The Rising Share of British Industrial Exports in Industrial Output, 1700-1851', Journal of Economic History, Vol. 57, no. 4, December 1997, pp.879-906.

'Dyestuffs in the Eighteenth Century', Economic History Review (New Series), Vol. 17, no. 3, 1965, pp.488-510.

'The Commercial Empire of the Atlantic, 1607-1783', Economic History Review (New Series), Vol. 15, no. 2, 1962, pp.205-18.

'Dublin Bay in the $18^{\text {th }}$ Century', Dublin Historical Record, 1977, pp.129-41.

'Eighteenth Century Shipping Tonnage Measurements', Journal of Economic History, Vol.33, no.2, June 1973, pp.434-43.

'English Population in the Eighteenth Century', Economic History Review (New Series), Vol. 6, no. 2, 1953, pp.11733.

'The Structure of the Trading Community in the Liverpool: 1760-1810', Transactions of the Historic Society of Lancashire and Cheshire, Vol. 151, December, 2002, pp.97125.

'The Medical Professions in the Eighteenth Century', Economic History Review (New Series), Vol. 4, no. 2, 1951, pp.141-69.

Holm, Desiree Blankenburg, 'Business Networks and Cooperation in International Business Relationships', Journal of International Business Studies, Vol. 27, no. 5, 1996, pp.1033-53.

'Reforming Britain's weights and measures, 1660-1824', English Historical Review, Vol. 108, no. 426, January 1993, pp.82-105.

'British Society in the Eighteenth Century', Journal of British Studies, Vol. 25, no. 4, October 1986, pp.436-66.

'A Tour Through Dublin City in 1782', Dublin Historical Record, Vol. 17, 1961-2, pp.2-12. 
Hyde, Francis E., Bradbury B. Parkinson, and Sheila Marriner
'The Port of Liverpool and the Crisis of 1793', Economica, (New Series), Vol. 18, no. 72, November 1951, pp.363-78.

Irish Committee of Historical Sciences and Irish Historical Studies

Writings on Irish History, 1989 \& 1990, Dublin, 1996.

Writings on Irish History, 1993 \& 1994, Dublin, 1999.

James, F. G.

'Irish Colonial Trade in the Eighteenth Century', William and Mary Quarterly, Vol. 20, no. 4, October 1963, pp.57484.

Kelly, Paul

'British and Irish Politics in 1785', English Historical Review, Vol. 90, no. 356, July 1975, pp.536-63.

Kennedy, Liam and

Martin W. Dowling,

'Prices and Wages in Ireland, 1700-1850', Irish Economic and Social History, Vol. 24, 1997, pp.62-104.

Large, David

'The wealth of the greater Irish landowners, 1750-1815', Irish Historical Studies, Vol. 15, 1966-7, pp.21-47.

Lee, J.

'Money and Beer in Ireland, 1790-1875', Economic History Review, (New Series), Vol. 19, no. 1, 1966, pp.183-94.

McCusker, John J.

'Colonial Tonnage Measurement: Five Philadelphia Merchants Ships as a Sample', Journal of Economic History, Vol.27, no.1, March 1967, pp.82-91.

'The Current Value of English Exports, 1697 to 1800', William and Mary Quarterly (3rd Series), Vol. 28, no. 4, October 1971, pp.607-28.

'Sources of Investment Capital in the Colonial Philadelphia Shipping Industry', Journal of Economic History, Vol. 32, no. 1, March 1972, pp.146-57.

McGilvray, James and David Simpson

'The Commodity Structure of Anglo-Irish Trade', Review of Economics and Statistics, Vol. 55, no. 4, November 1973, pp.451-8.

Mathias, Peter

The Brewing Industry in England, 1700-1830, Cambridge, 1959.

Merritt, J. E.

'The Triangular Trade', Business History, Vol. 3, no. 1, December 1960, pp.1-7.

Mokyr, Joel

'Malthusian Models and Irish History', Journal of Economic History, Vol. 40, no. 1, March 1980, pp.159-66. 
Mokyr, Joel and

Cormac O'Grada

Morgan, V. and

W. Macafee.

Moriarty, Thomas F.

Mortimer, Russell

Musson, A. E. and

E. Robinson

Nash, R. C.

Pollard, Sidney

Price, Jacob M.

Prior, Ann and

Maurice Kirby

Sawers, Larry

Sheridan, R. B.

Simms, J. G.

Smith, S. D.
'New Developments in Irish Population History, 17001850', Economic History Review, (New Series), Vol. 37, no. 4, November 1984, pp.473-88.

'Irish Population in the Pre-Famine Period: Evidence from County Antrim', Economic History Review (New Series), Vol. 37, no. 2, May 1984, pp.182-96.

'The Irish Absentee Tax Controversy of 1773: A Study in Anglo-Irish Politics on the Eve of the American Revolution', Proceedings of the American Philosophical Society, Vol. 118, no. 4, 13 September 1974, pp.370-408.

'Quaker Printers, 1750-1850', Friends Historical Society Journal, Vol. 50, 1963, pp.100-33.

'Science and Industry in the Late Eighteenth Century', Economic History Review (New Series), Vol. 13, no. 2, 1960, pp.222-44.

'Irish Atlantic Trade in the Seventeenth and Eighteenth Centuries', William and Mary Quarterly, Vol. 42, no. 3, July 1985, pp.329-56.

'A New Estimate of British Coal Production, 1750-1850', Economic History Review (New Series), Vol. 33, no. 2, May 1980, pp.212-35.

'What Did Merchants Do? Reflections on British Overseas Trade, 1660-1790', Journal of Economic History, Vol. 49, no. 2, June 1989, pp.267-84.

'The Society of Friends and the family firm, 1700-1830' Business History, Vol. 35, no. 4, October 1993, pp.66-85.

'The Navigation Acts Revisited', Economic History Review (New Series), Vol. 45, no. 2, May 1992, pp.262-84.

'The Wealth of Jamaica in the Eighteenth Century', Economic History Review (New Series), Vol. 18, no. 2, 1965, pp.292-311.

'Dublin in 1776', Dublin Historical Record, Vol. 31-2, 197780, pp.2-13.

'Prices and the Value of English Exports in the Eighteenth Century: Evidence from the North American Colonial Trade', Economic History Review (New Series), Vol. 48, no. 3, August 1995, pp.575-90. 
Sperling, J.

Thoms, D. W.

Wall, Maureen

Ward, J. R.

Williams, J. E.

Wolff, Klaus H.

Wrigley, E. A.

Vay, Milos and

Orsolya Szakaly
'The International Payments Mechanism in the Seventeenth and Eighteenth Centuries', Economic History Review, New Series, Vol. 14, no. 2, 1962, pp.446-8.

'The Mills Family: London Sugar merchants of the Eighteenth Century', Business History, Vol. 11, no. 1, January 1969, pp.3-10.

'The Rise of a Catholic Middle Class in EighteenthCentury Ireland,' Irish Historical Studies, Vol. 11, no. 42, September 1958, pp.91-115.

'The Industrial Revolution and British Imperialism, 17501850', Economic History Review (New Series), Vol. 47, no. 1, February 1994, pp.44-65.

'Whitehaven in the Eighteenth Century', Economic History Review, New Series, Vol. 8, no. 3, 1956, pp.393404.

'Textile Bleaching and the Birth of the Chemical Industry', Business History Review, Vol. 48, no. 2, Summer 1974, pp.143-63.

'Making Sense of Ireland's Economic Past', Irish Economic and Social History, Vol. 23, 1996, pp.113-6.

'Eighteenth-Century Dublin in the Eyes of a Hungarian Aristocrat', Irish Economic and Social History, Vol. 29, 2002, pp.56-70. 